Chicago-Kent College of Law

Scholarly Commons @ IIT Chicago-Kent College of Law

All Faculty Scholarship

Faculty Scholarship

March 2005

\title{
The Surprisingly Strong Case for Tailoring Constitutional Principles
}

Mark D. Rosen

IIT Chicago-Kent College of Law, mrosen1@kentlaw.iit.edu

Follow this and additional works at: https://scholarship.kentlaw.iit.edu/fac_schol

Part of the Constitutional Law Commons

\section{Recommended Citation}

Mark D. Rosen, The Surprisingly Strong Case for Tailoring Constitutional Principles, 153 U. Pa. L. Rev. 1513 (2005).

Available at: https://scholarship.kentlaw.iit.edu/fac_schol/528

This Article is brought to you for free and open access by the Faculty Scholarship at Scholarly Commons @ IIT Chicago-Kent College of Law. It has been accepted for inclusion in All Faculty Scholarship by an authorized administrator of Scholarly Commons @ IIT Chicago-Kent College of Law. For more information, please contact jwenger@kentlaw.iit.edu, ebarney@kentlaw.iit.edu. 
To appear in 153 University of Pennsylvania Law Review (forthcoming Spring 2005)

\section{The Surprisingly Strong Case For Tailoring Constitutional Principles}

Mark D. Rosen*

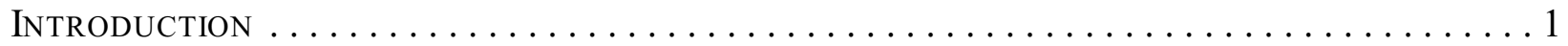

I. One-Size-Fits-All and TAiloring Identified $\ldots \ldots \ldots \ldots \ldots \ldots \ldots \ldots \ldots \ldots$

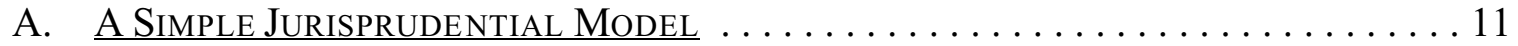

B. Four ApProaches to Importing Constitutional Principles $\ldots \ldots \ldots \ldots \ldots 13$

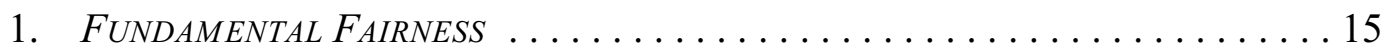

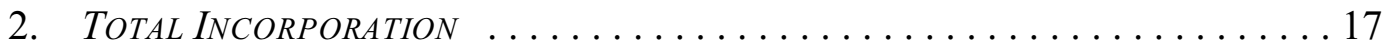

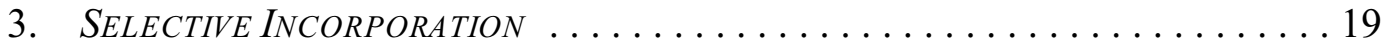

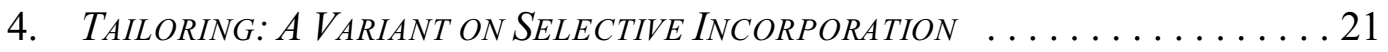

C. One-Size-Fits-All Outside of the Fourteenth Amendment $\ldots \ldots \ldots \ldots 23$

II. The (Ultimately) Pragmatic Grounds for One-Size-Fits-All $\ldots \ldots \ldots \ldots \ldots \ldots$

A. The Disappointing SeArch for a JustificAtion $\ldots \ldots \ldots \ldots \ldots \ldots \ldots \ldots . \ldots \ldots$

B. The "Watering-Down" Thesis And the Structure of Rights $\ldots . . \ldots . .29$

C. Plausible Justifications for Selective InCORPORATION AND THEIR RELATION

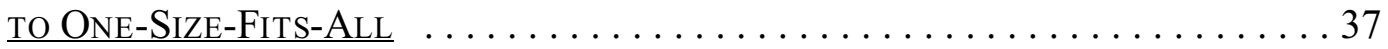

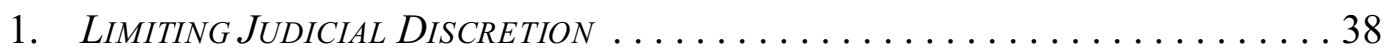

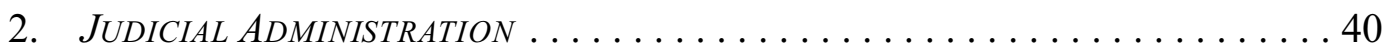

III. A Quasi-Precedential Argument: That Tailoring is Not Unknown to American

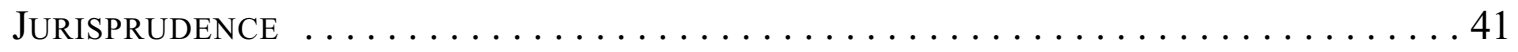

A. EARLy InFLUENTIAL SUPPORT FOR TAILORING $\ldots \ldots \ldots \ldots \ldots \ldots \ldots \ldots \ldots$

B. Contemporary Constitutional Decisions That Reflect the Logic of

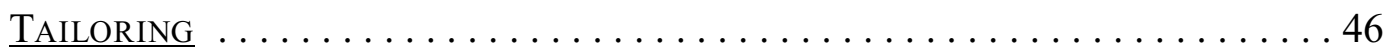

1. FEDERAL AFFIRMATIVE ACTION PROGRAMS . . . . . . . . . . . 47

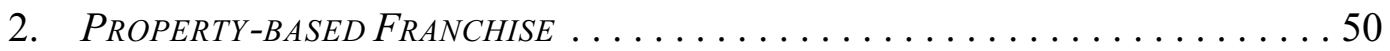

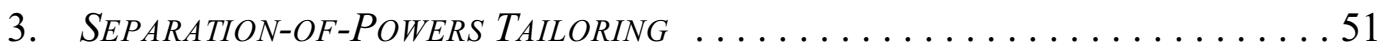

4. Dormant Commerce ClaUSE . . . . . . . . . . . . . . . . 56

5. Apportionment and other Methods for ENhancing the Political PoWer

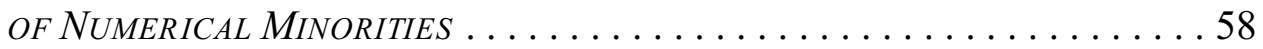

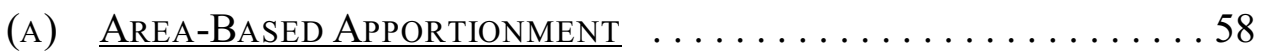

(B) State Analogs to the Electoral College $\ldots \ldots \ldots \ldots 60$

\footnotetext{
*Associate Professor, Chicago-Kent College of Law, Illinois Institute of Technology. I would like to thank Dan Farber, Clay Gillette, Steve Heyman, Roderick M. Hills, Jr., Dean Krent, Richard McAdams, Steven Shiffrin, Steve Smith, Richard Schragger, and Dina Warner. I also benefitted from feedback from faculty workshops at the ChicagoKent College of Law, the Indiana University Law School (Indianapolis), the St. Louis University School of Law, and the University of Illinois College of Law.
} 
(c) Population-Based Apportionment $\ldots \ldots \ldots \ldots \ldots \ldots \ldots 6 . \ldots \ldots$

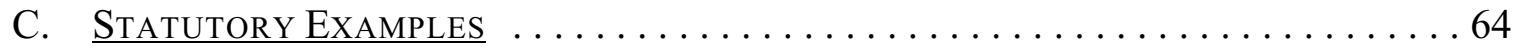

IV. The Prima Facie Case for Tailoring: That Different Levels of Government May

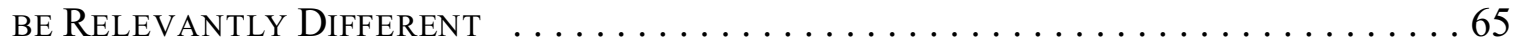

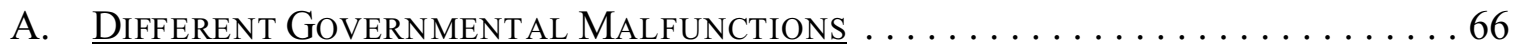

1. MALFUNCTIONS IN THE REPRESENTATIVE PROCESS ..............66 66

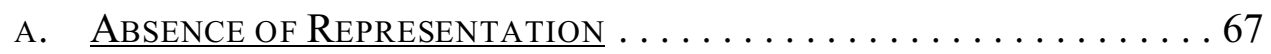

B. UNDER-REPRESENTATION ......................... 71

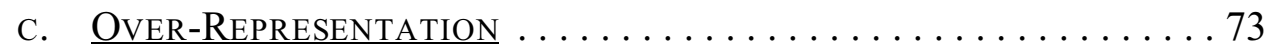

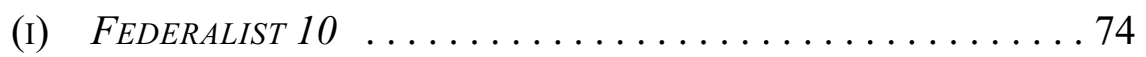

(II) KOMESAR's “TWO-ForCE” MODEL OF POLITICS ....... 75

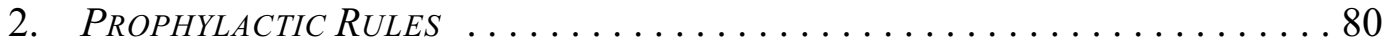

A. The Need to Over-Protect Constitutional Rights … $\ldots 81$

B. The Costs of Over-Protection $\ldots \ldots \ldots \ldots \ldots \ldots \ldots . .63$

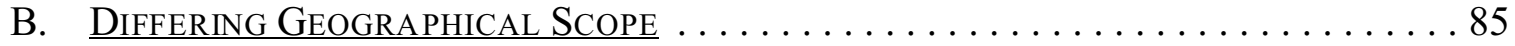

1. VARYING RISKS AND BENEFITS $\ldots \ldots \ldots \ldots \ldots \ldots \ldots \ldots \ldots \ldots$

2. VARYING EXPRESSIVE CONSEQUENCES $\ldots \ldots \ldots \ldots \ldots \ldots \ldots \ldots$

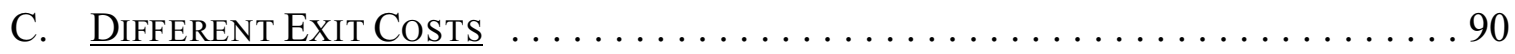

1. That Smaller Polities Have SMaller Exit Costs .............. 91

2. LAW AND ECONOMICS ......................... 92

3. ROBERT NOZICK'S "FRAMEWORK FOR UTOPIAS" ............... 96

D. DifFerent "We's" and Democratic Theory . .................... 99

1. OutSIDERS' EXtRATERRITORIAL INTERFERENCE VERSUS INSIDERS' SELF-

REGULATION ............................... 100

2. Limiting the Dilemmas of MAJORItaRIANisM $\ldots \ldots \ldots \ldots \ldots \ldots \ldots$

A. Multicultural Liberal Theorists $\ldots \ldots \ldots \ldots \ldots \ldots$

B. Rawlsian Political Liberalism .................... 109

E. Different Functions And ResponsibILITIES $\ldots \ldots \ldots \ldots \ldots \ldots \ldots \ldots \ldots$

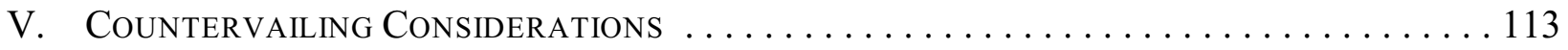

A. Administrability AND JUdiCIAL DisCRETION $\ldots \ldots \ldots \ldots \ldots \ldots \ldots \ldots \ldots . \ldots \ldots$

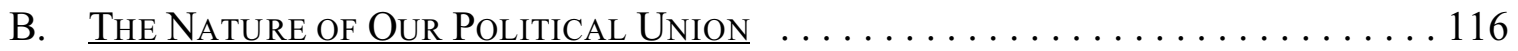

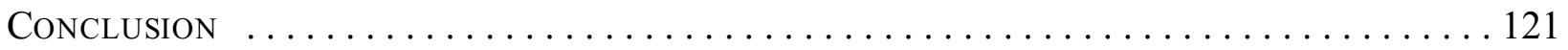


"In a large republic, the common good is sacrificed to a thousand considerations; it is subordinated to various exceptions; it depends on accidents. In a small republic, the public good is more strongly felt, better known, and closer to each citizen; abuses are less extensive, and consequently less protected."1

\section{INTRODUCTION}

Example, virtually all Bill of Rights guarantees, which long were understood to limit only the federal government, have been applied to the States through the Fourteenth Amendment under the doctrine of incorporation. ${ }^{2}$ Similarly, the Fourteenth Amendment's equal protection clause, which by its terms applies only to States, has been "reverse incorporated" against the federal government. "Multi-level" constitutional principles can be found outside the contexts of incorporation and reverse incorporation, as well. For example, the Court has held that a constitutional principle of representative democracy that prohibits the federal government from augmenting Article I's qualifications for Congress also applies to the States. ${ }^{4}$

The conventional wisdom is that such multi-level constitutional principles apply identically to all levels of government. Thus, the Court has held that incorporated Bill of Rights guarantees apply "with full force to the States." Similarly, when reverse incorporating, the Court has articulated the doctrine of "congruence," under which Equal Protection applies identically to the

\footnotetext{
${ }^{1}$ Montesquieu, De 1'Esprit des Lois (Paris, 1961). As should become clear during the course of the Article, I do not believe that constitutional protections always should be less searching in relation to smaller polities. The quotation from Montesquieu is notable insofar as it suggests that the appropriate scope of constitutional protections might be related to the size of the polity.

${ }^{2}$ See Barron v. City of Baltimore, 32 U.S. 243 (1833). The only exceptions are the Fifth Amendment's grand jury requirement, the Seventh Amendment civil jury requirement, the Second Amendment, and the Third Amendment.

${ }^{3}$ See Bolling v. Sharpe, 347 U.S. 497 (1954).

${ }^{4}$ See U.S. Term Limits, Inc. v. Thornton, 514 U.S. 779 (1995), discussed infra.

${ }^{5}$ Lee v. Weisman, 505 U.S. 577, 580 (1992) (Establishment Clause). See infra Part I.B.3.
} 
federal and sub-federal polities. ${ }^{6}$ And the principle of representative democracy limiting Congress was applied identically to the states. ${ }^{7}$ In short, today's doctrine virtually always utilizes what might be called a categorical "One-Size-Fits-All" approach to those constitutional principles that apply to more than one level of government.

The Article's thesis is that this categorical One-Size-Fits-All approach is problematic because the different levels of government - federal, state, and local - sometimes are sufficiently different that a given constitutional principle may apply differently to each level. This Article critically examines an alternative approach to One-Size-Fits-All that it dubs "Tailoring." Tailoring refers to the possibility, though not the requirement, that a constitutional provision may apply differently to different levels of government. Tailoring thus would permit a situation where the federal government could regulate in ways unavailable to the sub-federal polities as a matter of constitutional law. Conversely, states or localities other times might be permitted to regulate in ways that the federal government could not. Finally, Tailoring holds out the prospect that states and municipalities may be sufficiently different that constitutional principles also should be Tailored as between them. For example, states may be more similar to the federal government than to municipalities in some respects such that a constitutional limitation might forbid the federal and state governments, but not municipalities, from regulating in a particular instance.

This Article does not ask whether any particular constitutional provisions should be Tailored. It instead considers the antecedent question of whether Tailoring is a plausible technique to consider. An affirmative answer does not commit a person to the conclusion that any particular

\footnotetext{
${ }^{6}$ See Adarand Constructors, Inc. v. Pena, 515 U.S. 200, 226 (1995) (announcing the principle of "congruence between the standards applicable to federal and state racial classifications").

${ }^{7}$ See U.S. Term Limits, 505 U.S. at 820.
} 
Constitutional provision should be Tailored, but uncovers a new set of doctrinal options for consideration. In the end, the Article concludes that the One-Size-Fits-All approach should be softened from a categorical requirement to a rebuttable presumption.

Although Tailoring at first might sound completely outlandish, it is not wholly unfamiliar to American constitutional jurisprudence. As the Article shows, numerous Justices have argued that particular constitutional provisions apply differently to different levels of government - including Justices Holmes, Cardozo, Jackson, Harlan, Fortas, Powell, Stewart, Stevens, Blackmun, Ginsburg, Rehnquist, and Thomas. Consider, for example, Justice Stevens' dissent in the case of Adarand Constructors, Inc. v. Pena ${ }^{8}$ Prior to Adarand, state affirmative action programs were subject to strict scrutiny ${ }^{9}$ whereas federal programs only had to satisfy intermediate scrutiny under the rule announced in Metro Broadcasting. ${ }^{10}$ The Adarand majority announced the principle of "congruence" - the requirement that "[e]qual protection analysis in the Fifth Amendment area is the same as that under the Fourteenth Amendment"11 - to reverse Metro Broadcasting. ${ }^{12}$ Justice Stevens, joined by Justice Ginsburg, argued in dissent as follows:

The Court's concept of 'congruence' assumes that there is no significant difference between a decision by the Congress of the United States to adopt an affirmative-action program and such a decision by a State or a municipality. In my opinion that assumption is untenable. It ignores important practical and legal differences between federal and state or local decisionmakers. ${ }^{13}$

In short, Justices Stevens and Ginsburg contended that the constitutional principle of equal protection should be Tailored, and criticized the doctrine of "congruence" for adopting what this

\footnotetext{
${ }^{8} 515$ U.S. 200 (1995).

${ }^{9}$ This was the rule announced in Richmond v. J.A. Croson Co., 488 U.S. 469 (1989).

${ }^{10}$ See Metro Broadcasting Inc. v. FCC, 497 U.S. 547, 564-65 (1990).

${ }^{11}$ Adarand, 515 U.S. at 224 (quoting Buckley v. Valeo, 424 U.S. 1, 93 (1976)).

${ }^{12}$ Adarand, 515 U.S. at 227.

${ }^{13} \underline{\text { Id. at }} 249$ (Stevens, J., dissenting). See infra Part III.B.1 for further discussion.
} 
Article terms a One-Size-Fits-All approach.

Moreover, though not conceptualized as instances of Tailoring, several contemporary doctrines in fact vary in their application depending on what level of government they apply. For instance, although equal protection proscribes the federal and state governments from conditioning the right to vote on property ownership, certain local governments are allowed to utilize such voting requirements. ${ }^{14}$ Similarly, although the dormant commerce clause prohibits states from adopting protectionist measures that discriminate against sister-states, no such anti-protectionism principle has been reverse incorporated against the federal government. Consequently, Congress can authorize protectionist regulations that states cannot. ${ }^{15}$ As this Article explains, such variances are best understood as instances of Tailoring, not as simply odd and discrete exceptions to ordinary constitutional law.

Although Tailoring's sensitivity to the differences among different levels of government is not unknown to American constitutional law, the Court ignores such considerations most of the time. This inattentiveness has led to troubling legal analysis. Consider the plurality opinion in the case of U.S. Term Limits, Inc. v. Thornton. ${ }^{16}$ At issue was the constitutionality of an amendment to the Arkansas State Constitution that provided term limits for Arkansas' federal representatives. The amendment was passed by a ballot initiative that won nearly $60 \%$ of the popular votes and that carried every congressional district in the State. ${ }^{17}$ The plurality nevertheless struck it down on the ground that the amendment violated the "fundamental principle of our representative democracy" that "the people should choose whom they please to govern them," a principle that the Court had

\footnotetext{
${ }^{14}$ See infra Part III.B.2.

${ }^{15} \underline{\text { See }}$ infra Part III.B.4.

${ }^{16} 514$ U.S. 779 (1995).

${ }^{17} \underline{\text { Id. }}$ at 845 (Thomas, J., dissenting).
} 
identified in the earlier case of Powell v. Mc Cormack. ${ }^{18}$

This reasoning is paradoxical: how can it be that fundamental democratic principles required that the Court strike down an amendment that had been adopted by the direct vote of a majority of Arkansas' citizens? The plurality arrived at this puzzling rationale by reflexively invoking a OneSize-Fits-All jurisprudence that disregarded the differences between which level of government (federal or State) was acting. The "fundamental principle of our representative democracy" that "the people should choose whom they please to govern them" was a thoroughly sensible principle for the Court to rely upon in Powell, where a majority of citizens in New York's $18^{\text {th }}$ Congressional District had voted for Adam Clayton Powell, Jr. and members of Congress sought to keep Powell from taking his seat. After all, the additional qualifications for Representatives that Congress sought to impose in Powell interfered with the choice that had been made by those who lived in Powell's congressional district - the people whose preferences mattered in respect of selecting their representative for Congress. The plurality in Thornton gave no real thought to the significance of which level of government was imposing the limit on who could sit for Congress, asserting simply that "the source of the qualification is of little moment in assessing the qualification's restrictive impact."19 This was the plurality's predicate for concluding "we believe that state-imposed qualifications, as much as congressionally imposed qualifications, would undermine ... the right of the people to vote for whom they wish." ${ }^{20}$

This reasoning is specious. That "the source of the qualification is of little moment in

\footnotetext{
${ }^{18} 395$ U.S. 486 (1969). The plurality noted that this was the "most important[]" consideration in its rationale. See 514 U.S. at 806.

${ }^{19}$ Id. at 820 .

${ }^{20} \underline{I d}$.
} 
assessing the qualification's restrictive impact ${ }^{21}$ bears no relation to the question the Court was considering: the relevance of Powell's democratic principle to Thornton. Qualifications for who can sit for Congress are not per se unconstitutionally undemocratic - indeed, the Constitution itself sets qualifications. ${ }^{22}$ The pertinent consideration for purposes of basic democratic principles is who imposes them. In Powell, additional qualifications were imposed by people who were not part of the political community democratically entitled to select its representative for Congress; the Congressmen who sought to bar Powell from sitting did not reside in New York's $18^{\text {th }}$ Congressional District. That is why the additional qualifications interfered with the fundamental democratic principle that the choice of the relevant political community must be respected. In Thornton, by contrast, a majority of voters in every congressional district in Arkansas had voted for additional qualifications - term limits - that applied only to them. Because term limits reflected the choice of the relevant political community, overturning the Amendment cannot legitimately be justified on the basis of fundamental democratic principles. ${ }^{23}$ Thus, "the source of the qualification" is of decisive moment in assessing whether it is violative of, or instead consistent with, fundamental democratic principles. The plurality's fatally flawed rationale is part and parcel of a One-Size-FitsAll approach, which, by definition, ignores differences between the federal and state governments. The problematic plurality reasoning in Thornton helps illustrate a crucial larger point. The greater openness to Tailoring that this Article advocates is not important simply because many Justices over the past hundred years have called for Tailoring (which they have) or because several

\footnotetext{
${ }^{21} \underline{\text { Id. }}$ (emphasis supplied).

${ }^{22}$ See U.S. CONST. ARt. I, §2, cl. 2 (qualifications for Representatives); U.S. Const. ART. I, §3, cl. 3 (qualifications for Senators).

${ }^{23}$ The dissent made this point. See $\underline{i d}$. at 877 (Thomas, J., dissenting). I do not mean to suggest that there are no other plausible grounds for overturning the Arkansas amendment, but only that the plurality's self-described "most important[]" argument, $\underline{\mathrm{id}}$. at 806 , is unavailing.
} 
constitutional doctrines already reflect the logic of Tailoring (which they do); although these two observations should help smooth feathers ruffled by the mere notion of Tailoring by showing that Tailoring is by no means foreign to contemporary doctrine, they do not on their own explain why Tailoring should figure more prominently in our constitutional analysis. Rather, as an analysis of Thornton suggests, and as this Article will try to demonstrate, the legal community should be more open to Tailoring because systematically ignoring the differences among the different levels of government, as current doctrine does, leads to troubling consequences. ${ }^{24}$

Sensitivity to what level of government is acting - the conceptual core of Tailoring - is critical because the different levels of government are sufficiently dissimilar that a particular limitation as applied to one may have very different repercussions when applied to another. It turns out that, among other things, a categorical One-Size-Fits-All approach thwarts many of federalism's potential benefits. Sometimes One-Size-Fits-All hamstrings the federal government, subjecting it to constraints that are sensible for states or municipalities but not for our country's central government. Other times, One-Size-Fits-All chokes off the benefits of federalism by unnecessarily subjecting sub-federal polities to strict and uniform limitations that make sense only in respect of the federal government.

In short, constitutional analysis ignores at its own peril what level of government is acting because the different levels of government systematically vary in important ways. Ignoring these differences simplifies constitutional analysis, to be sure - but at a cost. There is no reason to

\footnotetext{
${ }^{24}$ As this Article shows, virtually no legal scholars have given attention to Tailoring either. After this Article was written, I learned of an excellent piece, since published, that considers what I call "tailoring" in the particular context of religious liberty. See Richard C. Schragger, The Role of the Local in the Doctrine and Discourse of Religious Liberty, 117 HARV. L. REV. 1810 (2004). I also have published a short piece that examined tailoring in the context of the establishment clause. See Mark D. Rosen, Establishment, Expressivism, and Federalism, 78 CHICAGO-KENT L. REV. 669 (2003).
} 
believe as an a priori matter that the cost is smaller than the administrative costs of developing more complex doctrine that takes account of systemic cross-polity differences. The desirability of tailoring constitutional doctrines to each polity requires an understanding of the opportunity costs of refusing to do so, as well as the administrative costs of Tailoring. This Article aims to identify both types of costs.

The Article is in five parts. Part I begins by formally defining One-Size-Fits-All and Tailoring. It shows that both within and outside of the Fourteenth Amendment, the Supreme Court virtually always adopts One-Size-Fits-All. Part I's analysis also clarifies Tailoring's precise relationship to the incorporation controversy and to contemporary black letter doctrine. Although Tailoring has important applications outside the contexts of incorporation and reverse incorporation (as shown by Thornton, for instance), Tailoring's significant implications in respect of incorporation and reverse incorporation merit such a clarification. Among other things, Part I shows that deciding the merits of Tailoring does not simply replay the incorporation debate of the 1950's and 1960's. Indeed, Tailoring is fully consistent with selective incorporation, what emerged as the doctrinal winner of that debate.

Part II shows that although today most multi-level constitutional principles are doctrinally treated as One-Size-Fits-All, the Supreme Court has not made much of an effort to justify such an approach. Part II argues that the Court's arguments for a categorical One-Size-Fits-All doctrine are unconvincing. Part II then surveys several scholars' attempts to justify the contemporary One-SizeFits-All approach. Part II concludes that there are two reasonably strong defenses for the status quo, but that they are pragmatic rather than theoretical justifications. As such, they do not support a categorical One-Size-Fits-All doctrine. Pragmatism invites consideration of the benefits and costs 
of alternatives to a One-Size-Fits-All approach and holds out the prospect that deviations from OneSize-Fits-All sometimes might be legitimate.

The Article's next two parts explain why Tailoring is a plausible doctrinal option that should be forthrightly considered, not dismissed out-of-hand by a categorical One-Size-Fits-All approach. Part III provides a quasi-precedential argument that is designed to show that Tailoring is not as foreign to American jurisprudence as may first appear. Part III's analysis is not (and cannot be) fully precedential, of course, because contemporary doctrine is One-Size-Fits-All, as shown in Part II. Nonetheless, it is instructive to understand that Tailoring has been propounded by a line of distinguished Supreme Court Justices for more than 75 years; that Tailoring already is found in several constitutional doctrines; and that some non-constitutional federal law reflects the logic of Tailoring as it distinguishes among the federal, state, and sub-state governments. This "precedent" collectively suggests that doctrinal sensitivity to what level of government is acting - Tailoring's conceptual core - already can be found in American law. Tailoring thus is not as novel as it might first appear.

Part IV identifies five respects in which the different levels of government might be sufficiently different to justify Tailoring. First, each level is susceptible to distinctive political malfunctions. Second, as a result of each level's particular geographical scope, identical restrictions may have systematically different consequences across the different levels of government. Third, because there are divergent exit costs across the different levels of government, there might be systematic variations with regard to whether and to what extent competition among polities can generate efficient and diverse public goods. Fourth, identical restrictions can have very different consequences vis-a-vis democracy since each level of government requires a different number of 
people to garner a majority and thereby translate its preferences into law. Fifth, and finally, each level of government may have certain distinctive responsibilities.

Part IV explains that whether any or all of these differences justifies Tailoring a given constitutional principle ultimately turns on what is best characterized as pre-constitutional, political commitments. Interestingly, however, a broad array of competing approaches to ordering social life that often generates conflicting policy prescriptions - including public choice theory, law and economics, Robert Nozick's political philosophy, Ely's process theory, multi-culturalist theorists Will Kymlicka and Charles Taylor, and Rawlsian political thought - finds one or more of these distinctions sufficient to support Tailoring. While Part IV does not take a position on the ultimate merits of these contested approaches to ordering social life, it does make the following point: the fact that many competing methodologies converge on the conclusion that Tailoring sometimes might be desirable counsels that constitutional doctrine should be responsive to potential differences among the various levels of government. This is the predicate for concluding that today's categorical OneSize-Fits-All approach is unwise.

Part V completes the Article's pragmatic analysis of Tailoring by considering Tailoring's potential costs. Although none gives rise to the conclusion that Tailoring is per se undesirable, several are very real countervailing considerations that are relevant to determining whether a particular constitutional provision should be Tailored. In conjunction with the conclusions of Parts III and IV, these potential costs to Tailoring suggest that contemporary doctrine should be modified, but not totally abandoned: One-Size-Fits-All should be downgraded from a categorical requirement to a rebuttable presumption. The recognition that Tailoring generates costs also heightens awareness of the subjectivity that invariably is involved in the choice between One-Size-Fits-All and Tailoring; 
trading-off between Tailoring's potential benefits and costs is a determination that is not susceptible to purely rational decisionmaking on account of the fact that Tailoring's potential benefits and costs are incommensurable. A short conclusion follows.

\section{One-Size-Fits-All AND TAILORING IDENTIFIED}

This Part introduces a simple jurisprudential model that permits a precise definition of Tailoring. This Part shows that the contemporary doctrine, within Fourteenth Amendment jurisprudence and more generally, is overwhelmingly of the One-Size-Fits-All character.

Importantly, Part I's model also precisely clarifies Tailoring's relationship to the doctrines of selective and reverse incorporation. Elucidating this relationship is important for three reasons. First, although Tailoring has significant applications throughout constitutional law, it has extensive relevance to Fourteenth and Fifth Amendment jurisprudence. Second, the clarification rebuts the misconception that advocacy of Tailoring is an invitation to revisit the incorporation controversy of the 1950 s and 1960 s, a hard fought battle in which a clear victor has emerged. ${ }^{25}$ It is not, for Tailoring is consistent with selective incorporation. Third, putting Tailoring into jurisprudential and historical perspective shows that Tailoring is less radical than it may sound at first. Tailoring is best understood as an alternative mode of selective incorporation that can realize many of the pragmatic benefits of the contemporary doctrine while shedding the doctrine's theoretically unjustifiable and unnecessarily cramping aspects.

A. A Simple Jurisprudential Model. Tailoring and One-Size-Fits-All are best understood in relation to a simple jurisprudential model that identifies the character of constitutional doctrine

\footnotetext{
${ }^{25}$ See, e.g., Michael C. Dorf, Equal Protection Incorporation, 88 VA. L. REV. 951, 968 (2002) ("Incorporation of the Bill of Rights is one of the few great success stories of modern constitutional law. Judges and constitutional scholars almost universally agree that, whatever else it does or does not do, the Fourteenth Amendment makes most of the provisions of the Bill of Rights applicable to the states and their subdivisions.")
} 
at any given point in time. ${ }^{26}$ The model builds on the commonly appreciated distinction between "rules" and "standards." 27 Standards are legal edicts that describe the trigger of legal consequences in "abstract terms that refer to the ultimate policy or goal animating the law." 28 Rules, by contrast, are legal edicts that "describe the triggering event with factual particulars or other language that is determinate within a community. ${ }^{, 29}$

Now to the model. Constitutional provisions typically take the form of standards that require active interpretation to identify concretely the actions that are required, permitted, or proscribed in particular circumstances. The interpretive process can be usefully conceptualized as involving three steps. Although the steps do not necessarily correspond to the chronology of the constitutional provisions' doctrinal development, ${ }^{30}$ identifying them is useful because they provide a means for comparing legal doctrine.

First, the constitutional provision can be identified with a general "Goal," by which I mean a broad-stroke description of what the provision attempts to accomplish. The Goal sets the parameters within which subsequent doctrinal development occurs. ${ }^{31}$ For example, the Goal of the Fourth Amendment has been identified as protecting various "personal and societal values" including

\footnotetext{
${ }^{26}$ I developed this model in an earlier article. See Mark D. Rosen, The Radical Possibility of Limited CommunityBased Interpretation of the Constitution, 43 WM. \& MARY L. REV. 927, 983 (2002).

${ }^{27}$ E.g., Frederick Schauer, Playing By the Rules: A Philos ophical Examination of Rule-Based Decision MAKING IN LAW AND IN LifE 102-04 \& 104 n.35 (1991); Louis Kaplow, Rules Versus Standards: An Economic Analysis, 42 Duke L. J. 557 (1992).

${ }^{28}$ Rosen, supra note 18 , at 623 .

${ }^{29}$ Id. at 623.

${ }^{30}$ See Mark D. Rosen, Multiple Authoritative Interpreters of Quasi-Constitutional Federal Law: Of Tribal Courts and the Indian Civil Rights Act, 69 FordHAm L. REv. 479, 490 (2000).

${ }^{31} I d$. at 490-91 \& nn.42-50. Perhaps counterintuitively, identification of the Goal frequently is not what happens first in time during the interpretive process. Once the Goal is identified, however, it affects sub sequent doctrinal development. Id. at 490 n. 43 .
} 
a "right to privacy." 32

The second step in the process is the creation of a "Legal Test" to determine whether the identified Goal is met. ${ }^{33}$ This second step occurs because the Goal inevitably is too abstract, and consequently, unworkable for the judiciary's institutional needs of having a shorthand method for decision making that identifies as legally relevant only a subset of the infinite facts that characterize any given circumstance. ${ }^{34}$ The test almost always includes one or more "Standards." For example, the Supreme Court has translated the previously mentioned Fourth Amendment Goal into a Legal Test composed of several Standards that ask whether "the individual manifested a subjective expectation of privacy in the object of the challenged search" and whether society is "willing to recognize that expectation as reasonable." ${ }^{\prime 35}$ This Legal Test helps to particularize the Goal, but by deploying Standards such as "expectation of privacy" and "reasonable," it still leaves ample uncertainty as to what concretely satisfies it.

Step three describes what occurs to the Legal Test's Standard over time. As the Standard is applied over a series of cases, it almost always becomes increasingly rule-like. This occurs because cases, by their nature, are disputes that involve particular facts. As the cases are decided they become showcases of what, as a concrete matter, the Standard requires. ${ }^{36}$ Step three's product is best

\footnotetext{
${ }^{32}$ Oliver v. United States, 466 U.S. 170, 177, 182-83 (1984). Although people typically view the contemporarily understood Goal as inevitable, the Goal almost always is a non-axiomatic translation of the constitutional provision. That is to say, a different Goal (or Goals) plausibly can be ascribed to the constitutional provision (and, frequently, have been, as an historical matter). Rosen, Of Tribal Courts, supra note 29, at 490 \& n.45.

${ }^{33}$ See id. at $490 \&$ n. 46.

${ }^{34} \underline{\mathrm{Cf}}$. Richard H. Fallon, Jr., Implementing the Constitution, 111 HARV. L. REv. 56, 57 (1997) ("Even when general agreement exists that the Constitution reflects a particular value or protective purpose ... the norms reflecting purposes such as these are too vague to serve as rules of law; their effective implementation requires the crafting of doctrine by courts.").

${ }^{35}$ California v. Ciraolo, 476 U.S. 207, 211 (1986) (emphasis added).

${ }^{36}$ This process of utilizing case law to make standards more concrete is not logically necessary; some say, for instance, that it does not occur in French law. B arry Nicholas, Introduction to the French Law of Contract, in CoNTRACT Law Today: Anglo-French Comparisons 7, 9-10 (Donald Harris \& Denis Tallon eds., 1989). It is, however, an
} 
identified as a "Rulified Standard." For example, do people have a "subjective expectation of privacy" in open fields? The Court has said no. ${ }^{37}$ In curtilage surrounded by a high double fence? Not from a naked-eye observation made from an aircraft, according to the Court. ${ }^{38}$

This simple model of interpretation can be graphically depicted as follows in Figure One:

\section{FIGURE ONE}

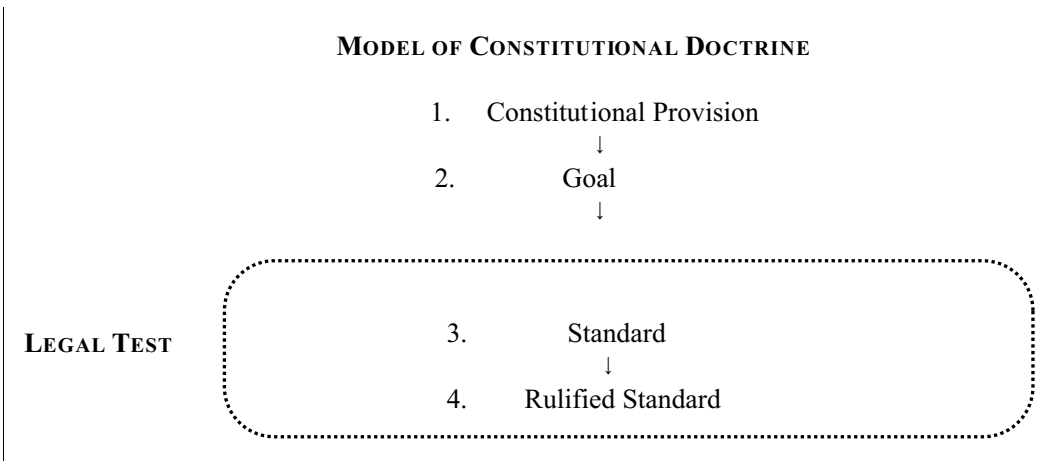

As we shall see, this simple model provides clarity with regard to the multifarious approaches to understanding the constitutional limitations applicable to States that Justices have advocated since the adoption of the Fourteenth Amendment.

B. Four Approaches to Importing Constitutional Principles. The issue of Tailoring arises when a federal constitutional guarantee applies to more than one type of government (for example, federal and state). We first must be attentive, therefore, to the threshold question of what levels of government are regulated by the Constitution. There are five possible ways that a constitutional

accurate depiction of what happens under the United States' common law method of constitutional adjudication. Strauss, supra note 202, at 877-906.

${ }^{37}$ See Oliver, 466 U.S. at 177.

${ }^{38}$ Id. at 209-10 (quoting Ciraolo, 476 U.S. at 211 (emphasis added)). 
principle might limit two or more levels of government. First, a constitutional provision might explicitly apply to several levels of government. As it so happens, virtually none do. ${ }^{39}$ The bulk of the United States Constitution applies by its terms only to the federal government. For example, many of the Bill of Rights by their terms address only the federal government,${ }^{40}$ and the landmark case of Barron v. City of Baltimore ${ }^{41}$ famously held in 1833 that none of the Bill of Rights applied to the sub-federal polities. ${ }^{42}$ Conversely, the provisions at the end of Article I apply by their terms to the States, but not to the federal government. ${ }^{43}$

Barron's rule unquestionably continued to be the law up to the adoption of the Civil Rights Amendments. The new amendments by their terms contained many new limitations on States. But what precisely was the requirement of "due process" and the curb that states not impinge on the "privileges or immunities" of their citizens? ${ }^{44}$ And what relationship did these new limitations bear to the constitutional constraints that applied to the federal government?

The jurisprudential model introduced above helps to distinguish four plausible approaches

\footnotetext{
${ }^{39}$ One example is the Fourteenth Amendment's citizenship Clause, which the Court has held applies to both the State and federal governments. See Saenz v. Roe, 526 U.S. 489, 500 (1999). For purposes of Tailoring, a provision that explicitly references both the federal and state governments and provides different explicit directions to each does not count. See, e.g., U.S. CONST. ART. I (selection of Senators). The doctrinal option of Tailoring that is this Article's subject does not arise if the Constitutional text already differentiates between different levels of government.

${ }^{40}$ For example, the First Amendment states that "Congress shall make no law respecting an establishment of religion, or prohibiting the free exercise thereof ..." U.S. Const. AmEND. 1, § 1, cl. 1 (emphasis supplied). The First, Sixth, and Seventh Amendments also explicitly address only the federal government.

4132 U.S. 243 (1833).

${ }^{42}$ See id. at 249-50. Chief Justice Marshall reasoned that the States each had established constitutions that defined and limited the ir state governments, whereas the United States Constitution was designed to define and limit the powers of the federal government, except where it explicitly applied to the States (as in Article I, section 10). The Chief Justice wrote that "Had Congress which proposed the amendments engaged in the extraordinary occupation of improving the constitutions of the several states by affording the people additional protection from the exercise of power by their own governments in matters which concerned themselves alone, they would have declared this purpose in plain and intelligible language. Id. at 250; see also $\underline{\mathrm{id}}$. at 247 (the Constitution's "limitations on power ... are naturally, and, we think, necessarily applicable to the government created by the instrument," and not to "distinct [state] governments, framed by different persons and for different purposes").

${ }^{43}$ See U.S. CONST., ART. I, $\S \S 9-10$.

${ }^{44}$ See U.S. Const., Amendment XIV.
} 
to identifying constitutional limitations on the States in circumstances where the constitutional limitation explicitly applies only to the federal government (and, mutatis mutandis, when exporting to the federal government constitutional principles that by their terms apply to the States). All four approaches, we shall see, have been advocated by Justices at different points in time. Two have commanded majorities, and one is the current black letter law. Importantly, the four approaches also are paradigms for the interpretation of those multi-level constitutional principles that are not connected to either the Fourteenth or Fifth Amendment due process clauses.

1. Fundamental Fairness. The four approaches are best appreciated in relation to a concrete constitutional guarantee. Let us take the Fifth Amendment's double jeopardy clause. At issue in Palko v. Connecticut ${ }^{45}$ was the constitutionality of a state statute that gave the government the same right of appeal as the criminal defendant. The Palko Court recognized that an earlier Supreme Court decision ${ }^{46}$ had held that the protection again double jeopardy "was not confined to jeopardy in a new and independent case" but "forbade jeopardy in the same case if the new trial was at the insistence of the government and not upon defendant's motion., ${ }^{47}$ This principle meant that a federal statute allowing the government a right of appeal from a conviction would violate double jeopardy. ${ }^{48}$

The question presented in Palko was whether there is such a guarantee in state courts.

\footnotetext{
${ }^{45} 302$ U.S. 319 (1937).

${ }^{46}$ That decision was Kepner v. United States, 195 U.S. 100 (1904). In fact, Kepner involved construction of federal legislation applicable to the Philippine Islands that incorporated virtually all of the Bill of Rights' guarantees. See $\underline{\mathrm{id}}$. at 123-25. The Kepner Court chose to construe this statutory language in the same manner that it would have interpreted the constitutional language. Id. at 124-25. Palko accordingly treated the constitutional question to have be en settled in Kepner. Palko, 302 U.S. at 323. Though Palko's approach in this regard is beyond reproach, Kempner could have resolved the question before it differently. Indeed, the Supreme Court has held that a twentieth century statute applicable in Indian country that incorporates language of the Bill of Rights can be construed differently than the Bill of Rights. See Rosen, Of Tribal Courts, supra note 29, at 487.

${ }^{47}$ Palko, 302 U.S. at 322-23.

${ }^{48}$ Id. at 323.
} 
Writing for the Court, Justice Cardozo considered appellant's argument that "[w]hatever would be a violation of the original bill of rights (Amendments 1 to 8 ) if done by the federal government is now equally unlawful by force of the Fourteenth Amendment if done by a state." ${ }^{49}$ Justice Cardozo's answer was short and simple: "There is no such general rule." ${ }^{.50}$ The question instead was what was required by the Fourteenth Amendment's due process clause, and that was answered by asking whether the challenged practice "violate[d] those fundamental principles of liberty and justice which lie at the base of all our civil and political institutions?"51 (The Court answered "no."). The Palko Court's method has been dubbed the "Fundamental Fairness" approach, ${ }^{52}$ and it commanded a majority of the Supreme Court for nearly the first hundred years after the Fourteenth Amendment's enactment..$^{53}$

The following chart illustrates this interpretive approach:

\footnotetext{
${ }^{49}$ Id. at 323 .

${ }^{50}$ Id. Justice Cardozo's choice of the word "general" is significant, for he noted later in the Palko opinion that certain constitutional rights were treated differently. See infra Part I.A.3; see also Adamson v. California, 332 U.S. 46, 85 (Black, J., dissenting) ("[i]mplicit in this statement ... is the understanding that some of the eight amendment do apply by their very terms.").

${ }^{51}$ Id. at 328 (internal quotation omitted).

${ }^{52}$ See, e.g.,Jerold H. Israel, Selective Incorporation: Revisited, 71 Geo. L. J. 253, 257, 291 (1982).

${ }^{53}$ See $\underline{\text { id. }}$.
} 


\section{Figure 2: Illustration of "Fundamental Fairness"}

\begin{tabular}{|l|l|l|}
\hline Model of Constitutional Doctrine & $\begin{array}{l}\text { Doctrine applicable to the Federal } \\
\text { Government }\end{array}$ & $\begin{array}{l}\text { Doctrine Applicable to the State } \\
\text { Government, Approach 1 (Fundamental } \\
\text { Fairness): }\end{array}$ \\
\hline $\begin{array}{l}\text { 1.Constitutional Provision } \\
\downarrow\end{array}$ & $\begin{array}{l}\text { 1.F: Fifth Amendment's double jeopardy } \\
\text { guarantee }\end{array}$ & 1.S: Due Process \\
\hline $\begin{array}{c}\text { 2. Goal } \\
\downarrow\end{array}$ & $\begin{array}{l}\text { 2.F: "A man shall not be brought into } \\
\text { danger of his life for one and the same } \\
\text { offense more than once." Kepner, 195 U.S. } \\
\text { at } 126 .\end{array}$ & $\begin{array}{l}\text { 2.S: makes certain that state procedures do } \\
\text { not violate those fundamental principles of } \\
\text { liberty and justice. }\end{array}$ \\
\hline $\begin{array}{c}1 . \quad \text { Standard } \\
\downarrow\end{array}$ & $\begin{array}{l}\text { 3.F: No person can be “again tried for the } \\
\text { same offense." Id. at 130. }\end{array}$ & $\begin{array}{l}\text { 3.S: Is the policy “so acute and shocking } \\
\text { that our polity will not endure it?" Palko, } \\
\text { 302 U.S. at 328. }\end{array}$ \\
\hline $4 . \quad$ Rulified Standard & $\begin{array}{l}\text { 4.F: Government cannot } \text { appeal an } \\
\text { acquittal. }\end{array}$ & 4.S: State can appeal from an acquittal. \\
\hline
\end{tabular}

Let the numbers $(1,2,3,4)$ represent each step in the jurisprudential model's representation of doctrinal development. "F" signifies "federal" doctrine, and "S' signifies "State." Under the first approach, the constitutional language applicable to the States is "Due Process," not "double jeopardy." ${ }^{, 54}$ In the model's representation,

\section{$\mathbf{1 . S} \neq \mathbf{1 . F}$ \\ 2.S does not $\left(\right.$ necessarily $\left.{ }^{55}\right)=2 . F$, 3.S does not (necessarily) $=3 . \mathrm{F}$, and 4.S does not (necessarily) $=4 . F$.}

The different levels of government are governed by different constitutional language, and the legal tests need not converge at any of the steps of the development of the two doctrines.

In short, under the fundamental fairness approach, there necessarily is incongruity at the first

\footnotetext{
${ }^{54}$ The Fourteenth Amendment's privileges or immunities clause was not a doctrinal option due to the Court's ruling in the Slaughterhouse Cases. See infra at 18 and following.

${ }^{55}$ I include the term "necessarily" because it is always possible that the identical Goal, Standard, or Rulified Standard could be imputed to two different constitutional provisions. The Court identified this possibility in the 1908 case of Twining v. New Jersey, 211 U.S. 78 (1908). The Court stated that "it is possible that some of the personal rights safeguarded by the first eight Amendments against national action may also be safeguarded against state action . . " Continued the Court, this was"not because those rights are enumerated in the first eight Amendments, but because they are of such a nature that they are included in the conception of due process of law." Id. at 99 . The Court's language can be represented by the model as follows: although 1 .S does not $=1$.F, it is possible that $2 . \mathrm{S}=2$.F .
} 
step of analysis, and there can be complete incongruity at all steps (as was the case in Palko).

Fundamental Fairness thus was a legal regime in which the federal and sub-federal governments frequently were subject to different constitutional limitations. ${ }^{56}$ Under Palko, for example, state prosecutors could appeal acquittals whereas federal prosecutors could not. States were subject to a host of constitutional limitations under the fundamental fairness regime, but the touchstone was what "fundamental fairness" required, not what limitations applied to the federal government. ${ }^{57}$

2. Total Incorporation. A second plausible approach is the polar opposite of Fundamental Fairness: to conclude that the language of the Fourteenth Amendment makes applicable to the States all doctrines that were developed in the federal context. In the model's representation, this would mean as follows:

$$
\begin{aligned}
& 1 . S=1 . F \\
& 2 . S=2 . F \\
& 3 . S=3 . F, \text { and } \\
& \text { 4.S }=\text { 4.F }
\end{aligned}
$$

This is an example of what this Article identifies as a "One-Size-Fits-All" approach. This was the method famously advocated by Justice Black in the 1947 case of Adamson v. California. ${ }^{58}$ In the

\footnotetext{
${ }^{56}$ See, e.g. Twining v. New Jersey, 211 U.S. 78, 113-14 (1908)(assuming that a jury instruction allowing juries to draw negative inference from a failure to testify would have violated the Fifth Amendment if administered in federal court, but holding that such an instruction did not violate the due process limitation that applied to the States); Maxwell v. Dow, 176 U.S. 581 (1900) (holding that a state statute providing for 8 rather than 12 person jury was not unconstitutional, despite the fact that the Sixth Amendment required 12 person juries in federal court); Betts v. Brady, 316 U.S. 455, 462 (1942) (holding that the due process clause was "less rigid and more fluid" than the Sixth Amendment); Wolf v. Colorado, 338 U.S. 25, 27 (1949) (holding that due process did not include the Fourth Amendment's exclusionary rule for illegally seized evidence).

${ }^{57}$ For example, it was held that due process prevented states from taking private property for public use without payment of just compensation, See Chicago, B. \& Q.R. Co.v. Chicago, 166 U.S. 226 (1896), protected against "arbitrary intrusion by the police," see Wolf v. Colorado, 338 U.S. 25, 27 (1949), and sometimes required representation by counsel. See Powell v. Alabama, 287 U.S. 45 (1932). For a full discussion, see Israel, Selective Incorporation Revisited, supra note 51 , at 284 .

${ }^{58} 332$ U.S. 46 (1947). Though not completely free from doubt, Justice Black's dissent appeared to adopt the position that all doctrinal details developed in the federal context applied equally to the States. See $\underline{\text { Id. }}$. at 86 (Black, J., dissenting) ("Nothing in the Palko opinion requires that when the Court decides that a Bill of Rights' provision is to be applied to the States, it is to be applied piecemeal. Nothing in the Palko opinion recommends that the Court apply part of an
} 
Fourteenth Amendment context, the Court and commentators have dubbed this position "total incorporation." ${ }^{59}$ Although four Justices embraced this approach in Adamson, total incorporation never commanded a majority of the Court. ${ }^{60}$ The functionally identical approach was advocated by Justice Bradley in the Slaughterhouse Cases, where he appeared to argue that the Fourteenth Amendment's privileges or immunities Clause made the Bill of Rights provisions applicable against the States. ${ }^{61}$ However, the Slaughterhouse majority famously narrowed the scope of the privileges or immunities clause in such a way that it could not serve this role, ${ }^{62}$ and Slaughterhouse is still good

amendment's established meaning and discard that part which does not suit the current style of fundamentals."). Justice Murphy's dissent in Adamson attributed this position to Justice Black, when he stated that he was "in substantial agreement with the views of" Justice Black with only "one reservation and one addition," addressed the question of doctrinal details. Id. at 124 (Murphy, J., dissenting). The first sentence, which purports to specify the aspects of the Black dissent with which he concurred, states "I agree that the specific guarantees of the Bill of Rights should be carried over intact into the first section of the Fourteenth Amendment." Id. (emphasis supplied). The word "intact" is best understood as referring to doctrinal details. Commentators have understood Black's dissent to encompass absorption of both all Bill of Rights guarantees as well as all doctrinal details. See, e.g., Israel, Selective Incorporation Revisited, supra note 51, at 257 ("The total incorporation position holds that the fourteenth amendment incorp orates all of the Bill of Rights guarantees and thereby applies those guarantees to state action in the same manner that they are applied to the actions of the federal government.") (emphasis supplied).

${ }^{59}$ See, e.g., Duncan v. Louisiana, 392 U.S. 947, xx (1968) (Harlan, J., dissenting); Israel, Selective Incorporation Revisited, supra note 51, at 257.

${ }^{60}$ See Israel, supra note 51 , at 286-90.

${ }^{61}$ See $\underline{\text { id. }}$. at 118-19 (Bradley, J., dissenting). Justice Bradley argued that arguing that the privileges or immunities clause of the Fourteenth Amendment included "the right of habeas corpus, the right of trial by jury, of free exercise of religious worship, the right of free speech and a free press, the right peaceably to assemble for the discussion of public measures, the right to be secure against unreasonable searches and seizures ..." $\underline{I d}$. A subsequent opinion authored by Justice Bradley raises questions as to whether he believed that the Fourteenth Amendment applied all Bill of Rights protections against the States. For a complete discussion, see Israel, Selective Incorporation Revisited, supra note 51, at $257 \&$ n. 20.

${ }^{62}$ Interestingly, notwithstanding the decision in the Slaughterhouse Cases, in five subsequent cases the Court was presented with arguments that the Fourteenth Amendment's privileges or immunities clause made various bill of rights protections applicable against the States. See In re Kemmler, 136 U.S. 436, 448 (1890); McElvine v. Brush, 142 U.S. 155, 159 (1891); O’Neil v. Vermont, 144 U.S. 323, 363 (1892) (Field, J., dissenting); Maxwell v. Dow, 176 U.S. 581 , 582 (1900); Twining v. New Jersey, 211 U.S. 78 (1908). The majorities reaffirmed Slaughterhouse in all these cases, though Justices Field, Harlan, and Brewer wrote dissenting opinions in several of them, arguing that the Fourteenth Amendment made the rights "enumerated in the earlier Amendments" applicable against the states. See, e.g., O'Neil v. Vermont, 144 U.S. at 370 (Harlan, J., dissenting). (Justice Field and the first Justice Harlan penned dissents in O'Neil v. Vermont. See $\underline{\mathrm{id}}$. at 363 (Field, J., dissenting); $\underline{\mathrm{id}}$. at 370 (Harlan, J., dissenting, joined by Brewer, J.). The first Justice Harlan also wrote dissents in Maxwell v. Dow, 176 U.S. 581, 605-17 (1900) (Harlan, J., dissenting), and in Twining v. New Jersey, 211 U.S. at 114-27 (Harlan, J., dissenting)). In the 1908 case of Twining v. New Jersey, 211 U.S. 78 (1908), the Court acknowledged that several Justices long had espoused the view that the privileges or immunities clause made the Bill of Rights applicable against the States, but declared that it was "not profitable to examine the weighty arguments in its favor, for the question is no longer open in the Court." Id. at 98. 
law. In short, neither the privileges or immunities clause nor due process has ever been interpreted to effectuate total incorporation.

3. Selective Incorporation. The third approach is illustrated by the contemporary doctrine widely known as "selective incorporation" (though I soon shall suggest that this terminology be slightly altered). Whereas total incorporation contemplates that the Fourteenth Amendment makes all Bill of Rights guarantees applicable against the States, not all Bill of Rights provisions necessarily apply under selective incorporation. ${ }^{63}$ For instance, advocates of selective incorporation have not campaigned for overturning long-established precedent holding that neither the Fifth Amendment's grand jury requirement ${ }^{64}$ nor the Seventh Amendment's civil jury guarantee apply to the States. ${ }^{65}$ Virtually all other Bill of Rights guarantees, however, have been held to be applicable against the States under selective incorporation. ${ }^{66}$ And where a guarantee applies, so do all doctrinal details that were developed in the federal context.

In practice, selective incorporation is not very different from total incorporation. Although the selective incorporation decisions typically continued to ask whether a particular constitutional guarantee was required under "fundamental fairness," they applied the test far more liberally than the Court had done during the "fundamental fairness" era. Justices embracing selective incorporation have concluded that the Constitution's specific enumeration of a guarantee is virtually conclusive evidence that the guarantee is "fundamental." incorporated against the States, the selective incorporation approach makes all doctrinal details that

\footnotetext{
${ }^{63}$ See Ohio ex rel. Eaton v. Price, 364 U.S. 263, 274 (1960) (per curium) (Brennan, J., joining).

${ }^{64}$ Hurtado v. California, 110 U.S. 516, 538 (1884) (holding that the grand jury right does not apply against the States).

${ }^{65}$ See Minneapolis \& St. Louis R. Co. v. Bombolis, 241 U.S. 211, 217 (1916) (holding that the Seventh Amendment's civil jury trial right does not apply against the States).

${ }^{66}$ See John E. Nowak \& Ronald D. Rotunda, Constitutional Law 431( $6{ }^{\text {th }}$ ed. 2000$)$.

${ }^{67}$ See Pacific Mutual Life Insurance Co. v. Haslip, 499 U.S. 1, 35 (1991) (Scalia, J., concurring).
} 
have been developed in the federal context applicable against the States, as well. For these reasons, the contemporary doctrine of selective incorporation is almost indistinguishable in practice from total incorporation.

The case of Benton v. Maryland, ${ }^{68}$ which reversed the Palko decision analyzed earlier, ${ }^{69}$ illustrates the contemporary doctrine of selective incorporation. Benton revisited the question of whether and to what extent the Fifth Amendment's protection against double jeopardy applied to the States. The majority wrote that "this Court has increasingly looked to the specific guarantees of the (Bill of Rights) to determine whether a state criminal trial was conducted with due process of law"70 and quickly concluded that "[t]he fundamental nature of the guarantee against double jeopardy can hardly be doubted" ${ }^{11}$ - in effect, that 1.S equals 1.F. The Court then asserted that "[o]nce it is decided that a particular Bill of Rights guarantee is fundamental to the American scheme of justice, the same constitutional standards apply against both the State and Federal Governments." ${ }^{" 72}$ The analysis proceeds as follows for those constitutional guarantees that are deemed to apply against the States under today's doctrine of selective incorporation:

$$
\begin{aligned}
& 1 . S=1 . F \\
& 2 . S=2 . F \\
& 3 . S=3 . F, \text { and } \\
& 4 . S=4 . F
\end{aligned}
$$

Selective incorporation thus utilizes a "One-Size-Fits-All” approach for every constitutional

\footnotetext{
${ }^{68} 395$ U.S. 784 (1969).

${ }^{69}$ See supra at p. 15.

${ }^{70}$ Benton, 395 U.S. at 794.

${ }^{71}$ Id. at 795 .

${ }^{72}$ Id. (emphasis supplied, internal quotation omitted).
} 
guarantee that is deemed to apply to the States. ${ }^{73}$ One-Size-Fits-All is the current black letter doctrine in both selective incorporation and reverse incorporation.

\section{Tailoring: A Variant on Selective Incorporation. The fourth and final doctrinal} approach is a variant of selective incorporation. Like selective incorporation, the fourth approach acknowledges that a guarantee's specific enumeration in the Bill of Rights is strong evidence that the guarantee is sufficiently fundamental to be applied against the States. Unlike the contemporary doctrine, however, the fourth approach contemplates that the doctrinal details developed in the federal context might not all transfer over to the States. In short, under this final approach,

$$
\begin{gathered}
1 . S=1 . F \\
2 . S=2 . F, \text { but } \\
\text { 3.S does not necessarily }=3 . F \text {, and } \\
\text { 4.S does not necessarily }=4 . F \text {. }
\end{gathered}
$$

\footnotetext{
${ }^{73}$ Even before selective incorporation's adoption in the 1960s, the Court employed a One-Size-Fits-All approach in its interpretation of many First Amendment guarantees beginning in the 1940s. In 1943, for instance, the Court noted "the special relationship of the Fourteenth Amendment to the rights of freedom of speech, press, and religion guaranteed by the First. We have repeatedly held that the Fourteenth Amendment has made applicable to the states the guaranties of the First." Douglas v. City of Jeannette, 319 U.S. 157, 162 (1943). The Court went on to hold in that case that "[a]llegations of fact sufficient to show deprivation of the right of free speech under the First Amendment are sufficient to establish deprivation of a constitutional right guaranteed by the Fourteenth ..." Id.

This One-Size-Fits-All approach consistently drew dissents. See, e.g., Jeannette (Frankfurter dissent); Barnette, 319 U.S. at 647 (Frankfurter, J., dissenting). The dissenters had the better of the argument. The majority that embraced One-Size-Fits-All with respect to the First Amendment rested their position on precedent. See, e.g., Jeanette, 319 U.S. at 162. The case law, how ever, hardly constituted precedent for a One-Size-Fits-All approach. The One-Size-Fits-All Justices relied heavily on Justice Cardozo's opinion in Palko, which stated that "the due process clause of the Fourteenth Amendment may make it unlawful for a state to abridge by its statutes the freedom of speech which the First Amendment safeguards against encroachment by the Congress, or the like freedom of the press, or the free exercise of religion, or the right of peaceable assembly." Palko, 302 U.S. at 324. Cardozo came to this conclusion, however, by means of a fundamental fairness methodology, not a One-Size-Fits-All rationale that willy nilly resulted in the adoption of all doctrinal details. Justice Cardozo wrote in Palko that the First Amendment guarantees "that are valid as against the federal government by force of the specific pledges of particular amendments" were "valid as against the states" not because they were enumerated in the Bill of Rights, but because they "have been found to be implicit in the concept of ordered liberty, and thus, through the Fourteenth Amendment, become valid as against the states." Palko, 302 U.S. at 324-25; see also id. at 326-27 (the Fourteenth Amendment "absorbed" the freedoms of "thought and speech" due to the "belief that neither liberty nor justice would ex ist if they were sacrificed," not because such freedoms were specified in the Bill of Rights). This rationale means that the general principles cross over to the State context, but it does not speak to doctrinal details. Notwithstanding its tenuous grounding in precedent, a One-Size-Fits-All approach vis-a-vis many First Amendment guarantees was securely in place during fundamental fairness's heyday, twenty years before the incorporation revolution.
} 
This is an example of what this Article dubs "Tailoring."

Many Justices have advocated this fourth doctrinal approach, including Justices Fortas, Stevens, Ginsburg, Powell, Rehnquist, and Thomas. ${ }^{74}$ In so doing, however, the Justices have not clearly distinguished their method from the contemporary doctrine of selective incorporation. Understanding this fourth possibility suggests that it is useful to distinguish between two types of "selective incorporation:" (1) selective and undifferentiated incorporation and (2) selective and differentiated incorporation. Consistent with ordinary usage, "selective" refers to the fact that not all Bill of Rights principles carry over to the States. "Undifferentiated" means that where a given principle is imported, all doctrinal details come along with it. "Differentiated" incorporation refers to a methodology that rejects the unreflective importation of all doctrinal details, though it does not mean that the doctrinal details necessarily differ across the different levels of government.

To summarize, selective and undifferentiated incorporation is a One-Size-Fits-All doctrine that reflects contemporary black letter law. Selective and differentiated incorporation, by contrast, is an example of Tailoring, and it has not been adopted by a majority of the Court.

It is useful to graphically compare the four approaches. Figure 3 arranges them, from left to right, on the basis of increasingly equivalent treatment of the different levels of government:

\footnotetext{
${ }^{74}$ See infra Part II.A. Justices Holmes, Jackson, Harlan advocated a similar approach, as will be discussed below. $\underline{\text { See }} \underline{\text { id. }}$.
} 
Figure 3: Four Approaches to Construing the $14^{\text {th }}$ Amendment

\begin{tabular}{|c|c|c|c|c|c|}
\hline $\begin{array}{l}\text { Model of } \\
\text { Constitutional } \\
\text { Doctrine }\end{array}$ & $\begin{array}{l}\text { Doctrine applicable } \\
\text { to the Federal } \\
\text { Government }\end{array}$ & $\begin{array}{l}\text { Fundamental } \\
\text { Fairness - black } \\
\text { letter law for 90+ } \\
\text { years }\end{array}$ & $\begin{array}{l}\text { Selective and } \\
\text { differentiated } \\
\begin{array}{l}\text { Incorporation - } \\
\text { this Article's } \\
\text { innovation }\end{array}\end{array}$ & $\begin{array}{l}\text { Selective and } \\
\text { undifferentiated } \\
\text { Incorporation - } \\
\text { black letter law } \\
\text { since the 1960s }\end{array}$ & $\begin{array}{l}\text { Total Incorporation } \\
\text { - Justices Black in } \\
\text { Adamson and } \\
\text { Bradley in } \\
\text { Slaughterhouse }\end{array}$ \\
\hline $\begin{array}{c}\text { 1.Constitution-al } \\
\text { Provision } \\
\downarrow\end{array}$ & 1.F. & $1 . S \neq 1 . F$ & $1 . \mathrm{S}=1 . \mathrm{F}$ & $\begin{array}{l}1 . S=1 . F \text { (whenever } \\
\text { a Bill of Rights } \\
\text { provision is } \\
\text { incorporated) }\end{array}$ & $\begin{array}{l}\text { 1.S }=1 . \mathrm{F} \text { for all Bill } \\
\text { of Rights provisions }\end{array}$ \\
\hline 2. Goal & 2.F. & $\begin{array}{l}\text { 2.S not necessarily } \\
=2 . \mathrm{F}\end{array}$ & $2 . S=2 . F$ & $\begin{array}{l}2 . S=2 . F \text { (whenever } \\
\text { a Bill of Rights } \\
\text { provision is } \\
\text { incorporated) }\end{array}$ & $\begin{array}{l}2 . S=2 . F \text { for all Bill } \\
\text { of Rights provisions }\end{array}$ \\
\hline 3. Standard & 3.F & $\begin{array}{l}\text { 3.S not necessarily } \\
=3 . \mathrm{F}\end{array}$ & $\begin{array}{l}3 . \mathrm{S} \text { does not } \\
\text { necessarily }=3 . \mathrm{F}\end{array}$ & $\begin{array}{l}3 . S=3 . F \text { (whenever } \\
\text { a Bill of Rights } \\
\text { provision is } \\
\text { incorporated) }\end{array}$ & $\begin{array}{l}\text { 3.S }=3 . \mathrm{F} \text { for all Bill } \\
\text { of Rights provisions }\end{array}$ \\
\hline $\begin{array}{l}\text { 4. Rulified } \\
\text { Standard }\end{array}$ & 4.F & $\begin{array}{l}4 . \mathrm{S} \text { not necessarily } \\
=4 . \mathrm{F}\end{array}$ & $\begin{array}{l}\text { 4.S does not } \\
\text { necessarily }=4 . \mathrm{F}\end{array}$ & $\begin{array}{l}\text { 4.S }=4 . \mathrm{F} \text { (whenever } \\
\text { a Bill of Rights } \\
\text { provision is } \\
\text { incorporated) }\end{array}$ & $\begin{array}{l}\text { 4.S }=4 . \mathrm{F} \text { for all Bill } \\
\text { of Rights provisions }\end{array}$ \\
\hline
\end{tabular}

C. One-Size-Fits-All Outside of the Fourteenth Amendment. Although the Fourteenth Amendment's due process clause is the most frequently used doctrinal conduit for exporting constitutional principles developed in the federal context to the States, it is important to bear in mind that not all multi-level constitutional principles spring from the due process clause. For instance, the principle identified by the Supreme Court in the Thornton decision - that additional qualifications for Congress violate a fundamental democratic principle - was not tied to the Fourteenth Amendment.

Whether a multi-level constitutional principle should be One-Size-Fits-All or Tailored accordingly arises outside the context of incorporation. As is the case with incorporation, the Court virtually always opts for One-Size-Fits-All. This is true of exports that originate from the federal 
side as well as the state side. To illustrate the former, it was held in Thornton that additional qualifications created by States are equally as problematic as those created by Congress. With regard to state exports, the Court in Saenz v. Roe $e^{75}$ held that the right to travel, which until then had been applied only against the States, applied in identical measure to the federal government. ${ }^{76}$

The Spending Clause is another doctrinal context where the Court has chosen One-Size-FitsAll over Tailoring. Though "Congress has wide latitude to attach conditions to the receipt of federal assistance in order to further its policy objectives," it "may not induce the recipient to engage in activities that would themselves be unconstitutional."77 The question for present purposes is whether the measure of what is unconstitutional potentially varies depending upon what level of government decides upon the regulation. The answer is "no" under One-Size-Fits-All, and "yes" under Tailoring.

To illustrate, consider the recently decided case of United States v. American Library Association. ${ }^{78}$ The Child Internet Protection Act (CIPA) required public libraries to use Internet filters as a condition for the receipt of federal subsidies. Filters are to prevent minors from obtaining access to harmful materials. Due to technological limitations, however, the filters block access to materials that are neither harmful to children nor to adults. ${ }^{79}$ Moreover, there are alternatives to the filters that could accomplish CIPA's goal of protecting minors without blocking access to the nonharmful materials. ${ }^{80}$

Six Justices analyzed the statute with a One-Size-Fits-All jurisprudence. The question for

\footnotetext{
${ }^{75} 526$ U.S. 489, 500 (1999).

${ }^{76}$ See infra at Part II.A.

${ }^{77}$ United States v. American Library Association, Inc., 123 S. Ct. 2297, 2303 (2003) (internal quotation and citations omitted).

${ }^{78} 123$ S. Ct. 2297 (2003).

${ }^{79}$ See $\underline{\text { id. }}$ at 2301-04.

${ }^{80}$ See $\underline{\text { id. }}$ at 2314 (Stevens, J., dissenting).
} 
them was whether a local public library could have constitutionally decided to install the filters. ${ }^{81}$ Justice Stevens expressly rejected the methodology embraced by the plurality and the Souter and Ginsburg dissents and instead adopted what this Article dubs Tailoring. Stevens "agree[d] with the plurality that it is neither inappropriate nor unconstitutional for a local library to experiment with filtering software as a means of curtailing children's access to Internet Web sites displaying sexually explicit images." Stevens accordingly "agree[d] with the plurality that the $7 \%$ of public libraries that decided to use such software on all of their Internet terminals in 2000 did not act unlawfully." 82 But, continued Justice Stevens, "[w] hether it is constitutional for the Congress of the United States to impose that requirement on the other 93\%, however, raises a vastly different question." ${ }^{\text {" } 3}$ That is to say, a local library's decision to install an Internet filter implicates the Constitution differently than the federal government's requirement that local libraries install such filters. The federal act "operates as a blunt nationwide restraint" whereas the library's decision is a decision by the locality that can be tailored to fit local circumstances. ${ }^{84}$ Thus, whereas Justice Stevens agreed that a local library's decision to install filters is constitutional, he concluded that Congress' indirect imposition of a nationwide requirement was not. ${ }^{85}$

\footnotetext{
${ }^{81}$ See $\underline{\text { id. }}$. at 2303 \& n. 2 ("we must ask whether the condition that Congress requires would be unconstitutional if performed by the library itself"(plurality, internal quotation and citation omitted)); 2320 ("The question for me, then, is whether a local library could itself constitutionally impose these restrictions ...") (Souter, J., dissenting, joined by Ginsburg, J.). The major difference between these Justices' analysis was as follows: while the plurality concluded that using the filters was analogous to a library's collection decision, which is subject only to rational basis scrutiny, see $\underline{\mathrm{id}}$. at 2306-07, Justice Souter (joined by Justice Ginsburg) believed the filters more akin to a library's decision to refuse certain patrons access to materials it already had in its collection, a censorship decision triggering strict scrutiny that filtering technology could not satisfy. See $\underline{\mathrm{id}}$. at 2320-2322; $\underline{\mathrm{id}}$. at 2321 ("The proper analogy therefore is not to passing up a book that might have been bought; it is either to buying a book and then keeping it from adults lacking an acc eptable 'purpose,' or to buying an encyclopedia and then cutting out pages with anything thought to be unsuitable for all adults.”).

${ }^{82}$ Id. at 2312-13 (Stevens, J., dissenting). Justices Souter and Ginsburg, by contrast, believed these libraries' activities to have been unconstitutional.

${ }^{83}$ Id. at 2313 (Stevens, J., dissenting).

${ }^{84}$ Id. ; see also id. at 2314-15 (Stevens, J., dissenting).

${ }^{85}$ Id. at 2318 (Stevens, J., dissenting).
} 
Justice Stevens' dissent thus spotlights the choice between One-Size-Fits-All and Tailoring that inheres in Spending Clause doctrine. Neither the plurality nor Justice Souter explained their selection of One-Size-Fits-All. ${ }^{86}$ Nor did they explain why Justice Stevens' approach was mistaken. It is not important for present purposes to consider which approach is correct, but to see that the contemporary doctrine reflects an One-Size-Fits-All approach. As will be shown in the next Part, the Court's failure to provide a justification for One-Size-Fits-All in the Spending Clause context is characteristic of the Court's tendency to reflexively adopt One-Size-Fits-All as if there were no alternative.

\section{The (Ultimately) Pragmatic Grounds for One-Size-Fits-All}

This Part II shows that the few justifications that the Supreme Court has offered for OneSize-Fits-All are inadequate. When the Court shifted from fundamental fairness to selective incorporation, it did not appear to appreciate that a choice had to be made about whether the imported principles were going to be One-Size-Fits-All or Tailored. The factors that led to the rejection of fundamental fairness in favor of selective incorporation did not likewise counsel the adoption of One-Size-Fits-All over Tailoring. Outside the context of incorporation, the Court also has neglected to provide adequate justifications for its selection of One-Size-Fits-All over Tailoring. As this Part II explains, the Court's unreflective adoption of One-Size-Fits-All probably is the outgrowth of a highly intuitive, but largely inaccurate, conception of constitutional rights. In the end,

\footnotetext{
${ }^{86}$ The plurality quoted language from South Dakota v. Dole, 483 U.S. 203 (1987), that was intended by the plurality to suggest that the question already had been decided. See American Library, $123 \mathrm{~S}$. Ct. at 2303 \& n.2. However, the choice between One-Size-Fits-All and Tailoring was not an issue that was decided in that case. Although the linguistic formulation of Dole's unconstitutionality prong more readily lends itself to One-Size-Fits-All than to Tailoring, that alone is not appropriately treated as deciding the question, particularly in view of the strong functionalist reasons Justice Stevens offers as to why an identical regulatory decision made by different levels of government might have very different constitutional implications.
} 
there are several strong justifications for One-Size-Fits-All, but they are pragmatic considerations rather than categorical imperatives. They accordingly do not justify today's doctrine of categorical One-Size-Fits-All.

A. The Disappointing Search for a Justification. Outside of incorporation, the Court's justifications for treating multi-level constitutional provisions as One-Size-Fits-All have amounted to no more than ipse dixit. In Thornton, the case concerning the constitutionality of term limits, the Court merely asserted that "the source of the qualification is of little moment in assessing the qualification's restrictive impact." ${ }^{87}$ In Saenz v. Roe, the Court answered the United States government's argument that the right to travel should be Tailored as between the federal and state governments ${ }^{88}$ with the unresponsive rejoinder that "the protection afforded to the citizen by the Citizenship Clause of [the $14^{\text {th }} \mathrm{A}$ ] is a limitation on the powers of the National Government as well as the States." 89 This is unresponsive because the U.S. government conceded that the right-to-travel limited the federal government, arguing only that the doctrinal details might vary as between the federal and state governments because "Congress stands in a different relation to individual citizens than do the legislatures of the several States, ${ }^{, 90}$ and the Court's explanation constitutes absolutely no justification whatsoever for rejecting Tailoring in favor of One-Size-Fits-All. Only by failing to appreciate the distinction between selective and undifferentiated incorporation, on the one hand, and selective and differentiated incorporation, on the other, can the Court's response in Saenz be

\footnotetext{
${ }^{87}$ U.S. Term Limits, Inc. v. Thornton, 514 U.S. 779, 820 (1995). For more discussion of Thornton, see $\underline{\text { infra Part }}$ IV.D.1.

${ }^{88}$ See Anderson v. Roe, United States Supreme Court Amicus Brief, 1998 WL 798866, *8*_*11(noting that "Congress has considered and acted on a question affecting the freedom of interstate migration- a freedom that has special structural characteristics and is in important respects a right of national citizenship, as to which Congress stands in a different relation to individual citizens than do the legislatures of the several States" and arguing that federal regulations accordingly should be subjected to lower level scrutiny)(emphasis supplied).

${ }^{89} 526$ U.S. 489, 500 (1999).

${ }^{90} \underline{\text { See }}$ Anderson v. Roe, United States Supreme Court Amicus Brief, 1998 WL 798866, *8*_*11.
} 
misconstrued as a justification for the doctrine that the Court embraced.

Although the question of whether a multi-level constitutional principle should be One-SizeFits-All or Tailored clearly arises outside the context of incorporation - as seen, for instance, in Thornton and in Saenz - outside the Fourteenth Amendment this question arises only on a right-byright basis that readily can escape scrutiny. Incorporation, by contrast, is a high profile, transsubstantive doctrine where the question of whether multi-level principles should be Tailored repeatedly occurs. For these reasons, it may be thought that solid justifications for One-Size-Fits-All can be found in the incorporation case law, and that the caselaw outside of incorporation implicitly relies on those justifications when it reflexively selects One-Size-Fits-All.

Case law in the incorporation context, however, has not been more illuminating. When the Supreme Court recently replaced a Tailored equal protection doctrine with the One-Size-Fits-All doctrine of "congruence" in the Adarand case over Justices Stevens and Ginsburg's dissent that urged continuation of Tailoring, the majority simply asserted that "[e]qual protection analysis in the Fifth Amendment area is the same as that under the Fourteenth Amendment." ${ }^{\prime 91}$

The paucity of recent justifications cannot be explained by the presence of a definitive justification for One-Size-Fits-All that was delivered in an earlier incorporation decision. The justifications the Court offered for rejecting fundamental fairness and adopting selective incorporation do not go to the question of whether the Bill of Rights principles that are imported through the portal of the Fourteenth Amendment are One-Size-Fits-All or Tailored. ${ }^{92}$ Consider three

\footnotetext{
${ }^{91}$ See Adarand Constructors, Inc. v. Pena, 515 U.S. 200, 224 (1995) (internal quotation omitted). For further discussion of Adarand, see infra Part III.B.1.

${ }^{92}$ This is not surprising, for it is widely appreciated that the Court has offered scant justification for selective incorporation itself, much less for having chosen one form of selective incorporation over another. See Israel, Selective Incorporation Revisited, supra note 51, at 301 ("the Court has yet to offer a full-fledged exposition of the doctrine's underlying justifications"); Henry Friendly, The Bill of Rights as a Code of Criminal Procedure, 53 CAL. L. REV. 929, 934 (1965) ("[i]t does seem extraordinary that a theory going to the very nature of our Constitution and having such
} 
possible justifications: text, history, and precedent. Textually, neither "due process" nor "privileges or immunities" answers the question: "due process" is a phrase that hardly appears to refer to the notion that Bill of Rights principles apply to the States, ${ }^{93}$ and even though the privileges or immunities clause may be a more plausible candidate than due process for incorporating the Bill of Rights,${ }^{94}$ the privilege or immunity clause's language does not speak to whether the doctrinal details developed in the federal context (steps 3.F and 4.F) should be applied to the states. Historically, even if there is evidence to support the view that the framers intended the privileges or immunities clause to incorporate the bill or rights ${ }^{95}$ - what is an issue of enduring dispute ${ }^{96}$ - the evidence is silent as regards the question of whether steps 3.F and 4.F were intended to transfer to the States. (The absence of textual and historical guidance in resolving the choice between One-Size-Fits-All and Tailoring is not surprising. The doctrinal details found at steps 3 and 4 constitute the

profound effects for all of us should be carrying the day without ever having been explicated in a majority opinion of the Court."); see also Dorf, Equal Protection Incorporation, supra note 24, at 969 ("As a matter of principle, there is much that is wrong with the argument that the enumeration of a right in one of the first eight amendment requires its application against the states").

${ }^{93}$ To quickly summarize several of the major textual critiques: (1) substantive due process is oxymoronic; $\underline{\text { see }}$ Dorf, supra note 24, at 969; (2) attributing such substantive meaning to the Fourteenth Amendment's due process clause makes the Fifth Amendment's due process clause redundant (insofar as such substantive protections already apply to the federal government via the Bill of Rights), ㅅ‥ at 969; (3) and "[i]t would be extraordinarily strange for a Constitution to convey such specific commands in such a round-about and inexplicit way" as through the due process clause. Adamson $\mathrm{v}$ California, 332 U.S. 46, 63 (1946) (Frankfurter, J., concurring).

${ }^{94}$ See Adamson v. California, 332 U.S. 46, 68-123 (Black, J., dissenting). Further, it has been argued that there is historical evidence to suggest that some of the Fourteenth Amendment's framers intended that the privileges or immunities clause would authorize Congress to compel the States to abide by the bill of rights. See MiCHAEL KENT Curtis, No State Shall Abridge: The Fourteenth Amendment and the Bill of Rights 81-82 (1986).

${ }^{95}$ To the extent the historical evidence supports the view that the privileges or immunities clause was intended to make the bill of rights applicable to the States, the evidence supports total incorporation, not selective incorporation. See Israel.

96 See, e.g., John Harrison, Reconstructing the Privileges or Immunities Clause, 101 YALE L. J. 1385, 1387-88 (1992)(arguing that privileges or immunities Clause was an equality-based, rather than a substantive-based, constitutional protection: "The main point of the clause is to require that every state give the same privileges and immunities of state citizenship-the same positive law rights of property, contract, and so forth-to all of its citizens."); see also DAVID P. Currie, The Constitution in the Supreme Court: The First Hundred Years 1789-1888, at 342-51 (1985)(same). In any event, all these scholars' understandings of the privileges or immunities clause remain mere theoretical inquiry for so long as the Court's early holding in the Slaughterhouse Cases remains good law. 
implementation of constitutional norms, which typically falls to courts, not legislatures. ${ }^{97}$ Most of the time, therefore, text and historical understandings are unlikely to shed light on the doctrinal details of steps 3 and $4 .{ }^{98}$ ) Finally, as regards precedent, the champions of selective incorporation could hardly have grounded their position on the earlier decided case law, which created the fundamental fairness regime that selective incorporation disassembled. ${ }^{99}$ Precedent accordingly could not have been the basis for selecting One-Size-Fits-All instead of Tailoring.

B. The "Watering-Down" Thesis and the Structure of Rights. The Court has offered one justification in the incorporation context specifically aimed at defending One-Size-Fits-All: that doing otherwise would lead to "watered-down" constitutional rights. ${ }^{100}$ Although the Court never went beyond this assertion to explain the theory behind it, I suspect that these words resonate with the intuitions of many. I shall dub this the "watering down" thesis. This section unpacks the thesis" unanalyzed assumption that the scope of a right defined in relation to limiting the federal government automatically carries over to other levels of government. It suggests that the watering down thesis is premised on a conception of constitutional rights that is widely held but largely inaccurate as a

\footnotetext{
${ }^{97}$ See Fallon, Implementing the Constitution, supra note 33, at 57, 61-67. The Religious Freedom Restoration Act is a rare exception.

${ }^{98}$ History is most likely to be illuminating vis-a-vis Steps 3 and 4 in respect of categorical Legal Rules. Consider the rule that the federal government is categorically prohibited from requiring state executive officials to apply federal law. See Printz v. United States, 521 U.S. 898, 935 (1997). A showing that the federal government actually did exercise such powers vis-a-vis states in the past would be relevant to determining whether a categorical rule comports with original understanding.

${ }^{99}$ See Israel, supra note 51, at 302-03. ("It may seem strange that a doctrine that resulted in the overruling of so many decisions has been justified by reference to prior precedent, but several Justices have offered precisely that justification for the selective incorporation doctrine."). Once selective incorporation was established, the Court openly acknowledged that its adoption had necessitated the abandonment of precedent. See Benton v. Maryland, 395 U.S. 784, 793-95 (1969) ("Palko's roots had thus been cut away years ago. We today only recognize the inevitable.").

${ }^{100}$ See, e.g., Gideon v. Wainwright, 372 U.S. 335, 346-47 (1963) (Douglas, J., concurring) (describing fundamental fairness approach as the "view that a guarantee of the Bill of Rights that is made applicable to the States by reason of the Fourteenth Amendment is a lesser version of the same guarantee as applied to the Federal Government . ..") (emphasis supplied); Malloy v. Hogan, 378 U.S. 1, 10-11 (1964) (holding that Court had "rejected the notion that the Fourteenth Amendment applies to the States only a 'watered-down,' subjective version of the individual guarantees of the Bill of Rights").
} 
purely descriptive matter. A more sophisticated conception that more accurately explains constitutional rights in this country undermines the assumption on which the watering down thesis rests.

One influential conception of rights, frequently associated with Ronald Dworkin, views rights as categorical trumps enjoyed by individuals as against majoritarian preferences. ${ }^{101}$ On this view, rights carve out spheres of immunity from governmental regulation so that individuals may engage in the activities that rights protect. ${ }^{102}$ A similar conception is present in those who speak of constitutional rights as being "rights, simpliciter" that guarantee that certain privileged conduct can occur. ${ }^{103}$ Much language in the Court's opinions is consistent with this conception of rights, and this conception is widely held. ${ }^{104}$

It quite naturally follows from this conception that the sphere of immunity a right creates should be equally impregnable by all levels of government. After all, if rights create spheres of immunity from regulation, it would contradict the very concept of a right to allow any level of government to regulate matters within this realm. Such conceptions of rights thus readily lead to

\footnotetext{
${ }^{101}$ See Richard H. Pildes, Why Rights are not Trumps: Social Meanings, Expressive Harms, and Constitutionalism, 27 J. Legal Stud. 725, 727-78 (1998) [hereinafter "Why Rights are not Trumps"]; see also Frederick Schauer and Richard H. Pildes, Electoral Exceptionalism and the First Amendment, 77 TEx. L. REv. 1803, 1809-19 (1997). Jeremy Waldron has responded that although many people hold the view that rights are categorical trumps and attribute that notion to Dworkin, Dworkin himself does not hold such a view. See Jeremy Waldron, Pildes on Dworkin's Theory of Rights, 29 J. Legal STUd. 301, 306 \& n. 22 (2000); but see Richard H. Pildes, Dworkin's Two Conceptions of Rights, 29 J. Legal STUD. 309 (2000) (responding that such a categorical trump conception is reflected in Dworkin's early writings). Regardless of what Dworkin's precise conception of rights might be, Waldron does not dispute Pildes' claim that Dworkin's work has "played an important role in fueling" the widespread view in contemporary political culture that constitutional rights are categorical trumps. See Pildes, Dworkin's Two Conceptions, 29 J. LeGAL STUD. at 311 ; Waldron, 29 J. LeGAL STUD. at 306 \& n. 22.

${ }^{102}$ Pildes, Why Rights are not Trumps, supra note 100, at 727-28.

${ }^{103}$ See, e.g., Michael C. Dorf, The Heterogeneity of Rights, 6 LEGAL TheORy 269, 271(2000) (defining a "right, simpliciter" $R$ as meaning that " $R$ provides a shield against all interferences with any conduct $C$ that constitutes an exercise of $R$.").

${ }^{104}$ See Pildes, Why Rights are not Trumps, supra note 100, at 727-728 (showing that this categorical understanding of rights as trumps is held by Michael Sandel, Allan Hutchinson, Charles Taylor, and Seymour Martin Lipset).
} 
One-Size-Fits-All. I suspect that this understanding of rights underlies the watering down thesis, though I admittedly cannot prove it since the Court has done nothing more than to assert the thesis. I also imagine that such a view, whether explicit or unstated, undergirds the intuition held by many that One-Size-Fits-All is the only intelligible approach to incorporation.

A competing conception of constitutional rights views rights as "shields against particular [governmental] rules." 105 Such "rights-against-rules" do not guarantee that particular conduct can occur, but guarantee only that conduct cannot be regulated by certain forms of governmental action. For instance, while the government may not proscribe the "desecrat[ion] [of a] ... state or national flag," ${ }^{106}$ the identical flag burning activity can be prohibited "pursuant to a rule against arson, assault, the destruction of government property, pollution, or some other such rule that was not targeted at speech." ${ }^{107}$ The Constitution thus does not guarantee a state of the world in which a person can burn an American flag. It only guarantees that the proscription will not assume a form that singles out the expressive activity of flag-burning. Burning a flag hence is not a "right, simpliciter," but a "right-against-rule."

Jurisprudential scholars who analyze the structure of rights concur that both types of rights - rights simpliciter and rights-against-rules - are found in American law. For example, the Constitution's ban on slavery is a "right[] not to have certain states of the world exist rather than [a

\footnotetext{
${ }^{105}$ Matthew D. Adler, Rights Against Rules: The Moral Structure of American Constitutional Law, 97 MiCH. L. REV. 1, 13 (1998). Richard Pildes has advanced a similar conception of rights. See Pildes, Why Rights are not Trumps, supra note 100, at 729-30 (discussed below in text).

${ }^{106}$ See Johnson v. Texas, 491 U.S. 397 (1989).

${ }^{107}$ Matthew D. Adler, Personal Rights and Rule-Dependence: Can the Two Coexist?, 6 LEGAL THEORY 337,344 (2000).
} 
] right[] not to be judged by certain kinds of rules" ${ }^{\prime 108}$ and accordingly creates a right, simpliciter. ${ }^{109}$ The flag burning case, by contrast, creates a right-against-rule. ${ }^{110}$ The jurisprudential dispute thus is one of degree rather than kind.

As a purely descriptive matter, most constitutional rights in the United States fit the structure of a right-against-rules. "[G]overnments can infringe even the most fundamental rights if its justifications are sufficiently 'compelling' and the means used are the least restrictive available."111 As such, "[r]ights are not general trumps against appeals to the common good" or creators of spheres of immunity from government regulation that guarantee a certain state in the world, but instead are "better understood as channeling the kinds of reasons government can invoke when it acts in certain arenas." "112 This structure of rights explains the widespread reality that Congress and the States can regulate such constitutionally protected matters as speech and abortion. ${ }^{113}$ Constitutional rights of the right-against-rule form do not categorically remove matters from majoritarian politics, but simply condition regulation on the presence of better-than-ordinary reasons for regulating and better-than-ordinary line-drawing when actually undertaking the regulation. Constitutionally permissible regulations of speech and abortion are difficult to reconcile, by contrast, with the conception of rights as creating spheres of immunity from regulation.

Importantly, the right-against-rules conception does not ineluctably lead to the watering-

\footnotetext{
${ }^{108}$ Dorf, Heterogeneity, supra note 102 , at $\mathrm{xx}$.

${ }^{109}$ Matthew Adler, the strongest proponent of the rights as "rights against rules" thesis, acknowledges this. See Matthew D. Adler, Rights, Rules, and the Structure of Constitutional Adjudication: A Response to Professor Fallon, 113 HARV. L. REV. 1371, 1374-75 (2000).

${ }^{110}$ See, e.g., Richard H. Fallon, Jr., As-Applied and Facial Challenges and Third-Party Standing, 113 HARV. L. REV. 1321, 1325 (2000); Dorf, Heterogeneity, supra note 102, at (agreeing that "rights as rights against rules is a plausible first-order approximation of much Supreme Court doctrine").

${ }^{111}$ Pildes, Why Rights are not Trumps, supra note 100, at 729.

${ }^{112}$ Id. at 729 .

${ }^{113}$ See Pildes, Why Rights are not Trumps, supra note 100, at 736-742.
} 
down thesis in the way that the rights simpliciter conception does. To the contrary, the right-againstrules structure provides prima facie support for Tailoring. Here is how. Once it is understood that rights invite special types of justifications, the question arises as to what types of justifications suffice to justify regulation. It has been argued that "context" plays a "crucial role" in determining what justifications suffice. ${ }^{114}$ Government creates different "institutional space[s]," ${ }^{, 15}$ and arguments that are sufficient to justify regulation in one context might not be satisfactory in another.

This seems right. Such an approach helps explain pockets of constitutional doctrine that are inexplicable under a categorical rights-as-trumps approach. For example, military officials are part of the federal government, and they are governed by the First Amendment. ${ }^{116}$ Yet they are permitted to proscribe speech that is merely "intemperate, . . disloyal, contemptuous and disrespectful," enact prior restraints, ${ }^{118}$ and to ban private citizens' political speech $^{119}$ - regulations that would not be permissible for other governmental actors. How is it possible that identical constitutional language - in this case, "free speech" - can mean different things in respect of different governmental actors? Theoretically indefensible under a categorical rights-as-trumps account, such regulations are comprehensible under a right-against-rules conception: context matters, and the institutional space known as the military has institutional characteristics very different from general society that accordingly may permit justifications for regulation that impermissible elsewhere. ${ }^{120}$ In fact, this is the precise rationale that the Supreme Court has provided for the unusual constitutional

\footnotetext{
${ }^{114}$ Id. at 739 ; see also Schauer and Pildes, Electoral Exceptionalism, supra note 100, at 1814-1819 (similar).

${ }^{115} \underline{\text { Id. }}$.

${ }^{116}$ See Mark D. Rosen, Our Nonuniform Constitution: Geographical Variations of Constitutional Requirements in the Aid of Community, 77 Tex. L. Rev. 1129, 1152-56 (1999).

${ }^{117}$ See Parker v. Levy, 417 U.S. 733, 739, 759 (1974).

${ }^{118}$ See Brown v. Glines, 444 U.S. 348 (1980) (upholding Air Force regulation requiring members of the service to obtain approval from commanders before circulating petitions on Air Force bases).

${ }^{119}$ See Greer v. Spock, 424 U.S. 828, 837-38 (1976).

${ }^{120}$ For more on this, see Rosen, Our Nonuniform Constitution, supra note 115, at 1152-56.
} 
doctrines that apply to the military: the Court has explained that 'the different character of the military community and of the military mission requires a different application of [constitutional] protections" 121 and that "fundamental necessit[ies]" of the military "may render permissible within the military that which would be constitutionally impermissible outside it."122

The understanding that many constitutional rights are rights-against-rules whose justifications for regulation frequently are context-sensitive explains several other pockets of oddly performing constitutional doctrine found in American law that are instructive to Tailoring. Like the military, public school officials are permitted to regulate speech and to conduct searches in ways that mill run government employees cannot. ${ }^{123}$ The same is true of prison officials. ${ }^{124}$ In all these contexts, identical constitutional language requires different things of different government officials. In the military, military officials are members of the federal government, and the doctrines that apply to the military differ at levels 3.F and 4.F. ${ }^{125}$ Sometimes, that is,

\footnotetext{
${ }^{121}$ Parker v. Levy, 417 U.S. 733, 759 (1974); see also Goldman v. Weinberger, 475 U.S. 503 , 507 (1986) ("Our review of military regulations challenged on First Amendment grounds is far more deferential than constitutional review of similar laws or regulations designed for civilian society").

${ }^{122}$ Parker, 417 U.S. at 758.

${ }^{123}$ See, e.g., Bethel School District No. 403 v. Fraser, 478 U.S. 675 (1986) (speech); Vernonia School District 47J v. Acton 515 U.S. 646 (1995)(search and seizure), discussed in Rosen, Our Nonuniform Constitution, supra note 115 , at $1159-61$.

${ }^{124}$ See, e.g., Turner v. Safley, 482 U.S. 78, 84 (1987)(adopting prison-specific First Amendment doctrine); $\underline{\text { see also }}$ Thornburgh v. Abbott, 490 U.S. 401, 407-10 (1989).

${ }^{125}$ See Rosen, Our Nonuniform Constitution, supra note 115, at 1142-47, 1152-56 (dubbing variations at 3.F. "restandardizing" and variations at 4.F "tailoring”).
} 


$$
\begin{aligned}
& 3 \cdot \mathrm{F}_{\text {(mill run federal actors) }} \neq 3 \cdot \mathrm{F}_{\text {(military), }} \text { and } / \text { or } \\
& 4 . \mathrm{F}_{\text {(mill run federal actors) }}
\end{aligned}
$$

Public schools are a form of local government, to which the Fourteenth Amendment applies, and the doctrines that apply to school officials also sometimes differ at the third and fourth levels of doctrine.

Sometimes, that is,

$$
\begin{gathered}
3 . \mathrm{F}_{\text {(mill run federal actors) }} \neq 3 . \mathrm{S}_{\text {(public school officials), }} \text { and } / \text { or } \\
4 . \mathrm{F}_{\text {(mill run federal actors) }} \neq 4 . \mathrm{S}_{\text {(public school officials) }}{ }^{27}
\end{gathered}
$$

In short, the constitutional doctrines that apply to the military and to public schools demonstrate that the doctrinal details of levels 3 and 4 do not invariably apply to all forms of government. Such variations are readily explainable as the natural consequence of the fact that these different types of governments (military, the schools) constitute different institutional contexts. Insofar as the doctrines associated with constitutional rights determine the types of reasons that provide a predicate for governmental regulation of the protected rights, it is not surprising that what constitutes a justifiable reason for regulation will vary from institutional context to context.

\footnotetext{
${ }^{126}$ For example, at a time when government regulations interfering with the free exercise of religion were analyzed under heightened scrutiny, the Court adopted a far more deferential reasonableness test when analyzing military regulations - a variation at the level of 3.F and thereafter at 4.F. In Goldman v. Weinberger, 475 U.S. 503 (1986), the Court ruled that instead of requiring restrictions affecting religious practice to be justified by a compelling governmental interest (as was required by the then-applicable test of Sherbert v. Verner, 374U.S. 398, 406 (1963)), the Court held that the military only had to show that its regulations were "reasonabl[e] and evenhanded[]." Goldman, 475 U.S. at 509-10. The Court forthrightly acknowledged that it the military was being subjected to a different legal test than applied to other levels of government, stating that "[o]ur review of military regulations challenged on First Amendment grounds is far

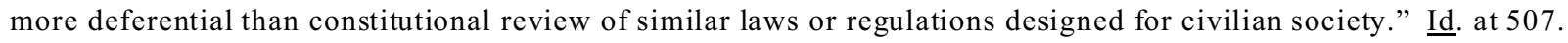

${ }^{127}$ For example, the Court applied a far more deferential legal test to school administrators than applies to virtually all other government officials in Hazelwood School District v. Kuhlmeier, 484 U.S. 260 (1988). Unlike the strict standard of review ordinarily applied to the censorship of "potentially sensitive topics" and unacceptable viewpoints, the Hazelwood Court determined that school officials were "entitled to regulate the contents" of school newspapers "in any reasonable manner." $\underline{\mathrm{Id}}$. at 270. In the language of this Article's model, 3.S. $\neq 3$.F and 4.S. $\neq 4$.F. As with military law, the Court has justified these variations on the basis of the unique institutional characteristics of public schools. The Court wrote that public schools must have the power to "refuse to sponsor student speech that might reasonably be perceived to advocate drug or alcohol use, irresponsible sex, or conduct otherwise inconsistent with the shared values of a civilized social order" or that "[o] therwise, the schools would be unduly constrained from fulfilling their role as a principal instrument in awakening the child to cultural values . . " Id. at 272. See generally Rosen, Our Nonuniform Constitution, supra note 115, at 1159-61.
} 
Consequently, what is constitutionally permissible may vary from institutional context to context, as well.

The role of institutional context in determining what justifications suffice to support regulation is not limited to the unusual doctrines that govern the military and public schools. Frederick Schauer and Rick Pildes have argued at length, for example, that mainstream First Amendment jurisprudence comprises multiple highly context-specific doctrines. Looking first to the political institution of elections, they note that

elections are already highly structured spheres, including regulations that would be impermissible in the general domain of public discourse. There are limits on what voters are permitted to express at the ballot box; mandatory disclosure obligations on the identity of political speakers; content-based regulations of electoral speech, ranging from mundane constraints like electioneering near polling places to more dramatic ones, like selective bans on contributions from some speakers ... 128

They then argue that such doctrinal "exceptionalism" is not unique to elections but in fact is generally characteristic of the First Amendment's political speech doctrine. They conclude that “[a]11 regulations of political speech are thus already measured by domain-specific, institutionspecific, sometimes media-specific, and generally context-specific First Amendment principles rather than some undifferentiated, 'general' First Amendment rule.",129

All this has critical consequences for Tailoring. Tailoring is just another example of the context-sensitize application of those constitutional principles that are best characterized as rightsagainst-rules. The predicate for Tailoring constitutional guarantees to the different levels of government is that each level may constitute a sufficiently different institutional context such that doctrinal variations at the levels of 3 and/or 4 are legitimate. Whether any particular doctrine is

\footnotetext{
${ }^{128}$ Schauer \& Pildes, Electoral Exceptionalism, supra note 100 , at 1816.

${ }^{129}$ Id. at 1824 .
} 
appropriately Tailored vis-a-vis any particular level of government is inevitably highly contextspecific, and accordingly falls outside of this Article's scope. As Part IV discusses, however, several generic considerations suggest that the federal, state, and local levels of government are sufficiently different such that the possibility of doctrinal variations at the levels of 3 and 4 as among these different levels of governments deserves serious consideration.

This analysis thus demonstrates the weakness of the watering-down thesis with respect to constitutional rights best characterized as rights-against-rules. The possibility that different levels of government are sufficiently different to require different justifications for regulating rights is what makes the unstated assumption that doctrinal details need apply equally across all institutional contexts wrong vis-a-vis such constitutional rights. On the other hand, the watering-down thesis is valid as against constitutional rights that fit the pattern of a right, simpliciter.

Consequently, it is important to distinguish constitutional rights that fit the structure of a right, simpliciter from those that constitute a right-against-rules. Commentators concur that both forms of rights are found in American constitutional law. There also is considerable agreement as to the rights that comprise each structure; for instance, that the Thirteenth Amendment's ban on slavery creates a right, simpliciter. Several have suggested that torture is another. ${ }^{130}$ Given the fact that there is not a unity structure to constitutional rights, but that they can assume two different forms,${ }^{131}$ it seems likely that in most cases "whether a right should be conceptualized as a rightagainst-rules or as a right, simpliciter, turns principally on substantive considerations about the

\footnotetext{
${ }^{130}$ See Adler, Rights Against Rules, supra note 104, at 7; Dorf, Heterogeneity, supra note 102, at $272 \& \mathrm{n} .14$.

${ }^{131}$ Pro fessor Fallon has suggested that "not all rights fit this framework at all," Fallon, As Applied, supra note 109, at 1366 , though he seems to concede that most rights are either rights simpliciter or rights-against-rules.
} 
particular right, rather than any deep fact about the structure of rights." ${ }^{, 132}$ If this is correct, as I think it is, the unreflective watering-down thesis is fatally undermined. Determining whether a constitutional right is a right, simpliciter, whose content necessarily is uniform vis-a-vis all polities, or a right-against-rules, for which a sufficient justification for regulation might vary across different institutional contexts, requires a highly particularized right-by-right analysis. The claim that variations across contexts constitute a watering-down of constitutional rights is not compelling.

C. Plausible Justifications for Selective Incorporation and their Relation to One-Size-FitsAll. Having surveyed in the last section several rationales for selective incorporation that do not justify the adoption of One-Size-Fits-All instead of Tailoring, this section identifies two justifications for selective incorporation that have been identified by the Court and commentators that are relevant to the choice between One-Size-Fits-All and Tailoring. The justifications identify pragmatic benefits of One-Size-Fits-All. Pragmatic justifications, however, by their nature invite the taking account of competing considerations and hence typically give rise to non-categorical rules. So too here: the justifications examined below give rise to a defeasible presumption of OneSize-Fits-All, but they do not support a categorical One-Size-Fits-All mode of selective incorporation. These justifications fully carry over to those contexts outside the Fourteenth Amendment when courts must determine whether a multi-level constitutional principle is to be Tailored or One-Size-Fits-All.

1. Limiting Judicial Discretion. Much of selective incorporation's success was due

\footnotetext{
${ }^{132}$ Dorf, Heterogeneity, supra note 102, at 272. It accordingly is not surprising that there are disagreements on both positive and normative grounds as to which pattern particular rights fit. See, e.g., Fallon, As Applied, supra note 109, at 1366 (citing as an example of "rights that do not fit the rights-against rules paradigm" that "a criminal or civil defendant always has a right to procedural due process" and noting that "although this right could possibly be represented as a series of rights against particular rules that violate due process, or as a right against putative general rules authorizing criminal and civil proceedings insofar as they fail to preclude due process violations, more would be lost than gained by so attenuated an account.").
} 
to justifiable dissatisfaction with the fundamental fairness regime that preceded it. Many decisions under fundamental fairness were criticized as subjective and unpredictable. ${ }^{133}$ Justices sought a method for cabining judicial discretion, ${ }^{134}$ and incorporation held out promise in this regard because the Bill of Rights terms of "free speech" and "search and seizure" are unquestionably more specific than "fundamental fairness."

Limiting judicial discretion in this fashion is sensible. Selective incorporation in effect means that guarantees specified in the Bill of Rights are presumptively assumed to apply against the States (in contrast to being categorically presumed to apply, as under total incorporation). "Fundamentality" still is the touchstone under selective incorporation for determining whether a given Bill of Rights guarantee applies to the States, and surely there is good sense in concluding that "what is important enough to have been included within the Bill of Rights has good claim to being an element of 'fundamental fairness."' 135

Is it the case, however, that the doctrinal details developed vis-a-vis the federal government invariably have good claim to being an element of fundamental fairness as well? The answer depends upon the structure of the constitutional right that is at issue: "yes" as regards a right, simpliciter, but "not necessarily" with regard to a right-against-rule. With regard to the latter, the particular legal rule that is utilized to implement a constitutional principle is a function of a host of contingent factors, ${ }^{136}$ many of which conceivably could vary across different levels of government. There is no good reason for categorically presuming that the Legal Test itself is "fundamental."

\footnotetext{
${ }^{133}$ See Israel, supra note 51, at 286-90.

${ }^{134}$ See $\underline{\text { id.; }} \underline{\text { see also }}$ Dorf, supra note 24, at 968-69.

${ }^{135}$ Pacific Mutual Life Insurance Co. v. Haslip, 499 U.S. 1, 35 (1991) (Scalia, J., concurring); see also Dorf, supra note 24, at 971 (noting that "those values that find their way into the constitutional text are likely to be the ones most fundamentally embraced by the American people.").

${ }^{136}$ See Fallon, Implementing the Constitution, supra note 33, at $\mathrm{xx}$.
} 
It might be responded that even if the doctrinal details at steps 3 and 4 are not themselves "fundamental," One-Size-Fits-All still has the great virtue of limiting judicial discretion. This is true, but the important question is "at what cost?" Judicial discretion would be curtailed if all constitutional doctrine were replaced by a single, simple legal rule. No one would advocate such a position because the costs of limiting judicial discretion in this fashion would be too great; doctrinal complexity is necessitated by the complex competing interests among which constitutional doctrine must mediate. Selective incorporation's check on judicial discretion is justifiable only because it is sensible to conclude that general principles constraining federal powers found in the Bill of Rights are (presumptively) fundamental and, accordingly, (presumptively ${ }^{137}$ ) applicable to the States. If the same cannot be said about the doctrinal details that were developed in the federal context, then we cannot be so certain that the benefits of limiting judicial discretion in this regard are worth the costs, identified in Part IV, of foregoing the option of Tailoring.

In short, though limiting judicial discretion is a very real benefit, it is a pragmatic consideration that is not a categorical trump. The interest in limiting judicial discretion may well justify a presumption of One-Size-Fits-All, but it cannot justify a categorical rule of One-Size-FitsAll.

2. Judicial Administration. A second justification for selective incorporation is that it facilitates judicial administration. ${ }^{138}$ It was very difficult for States to know what was constitutionally required of them under fundamental fairness because the Court refused to generate broadly applicable legal principles. ${ }^{139}$ Instead, the Court's holdings were highly context specific.

\footnotetext{
${ }^{137}$ I say "presumptively" because under selective incorporation, in contrast to total incorporation, it is not the case that all bill of rights principles apply to the States.

${ }^{138}$ See Israel, supra note 51, at 310-11.

${ }^{139}$ See id. at $310-13$.
} 
For example, the Court held that whether disallowing a criminal defendant in state court from having an attorney violated fundamental fairness turned on such fact-specific variables as the severity of the imposed sentence and the defendant's capacity to defend herself. ${ }^{140}$ This offered States precious little guidance. The selective incorporation adopted by the Court - that is, of the OneSize-Fits-All variety - had the benefit of making an already-developed and readily ascertained body of doctrine applicable to the States. State officials accordingly had a ready body of constitutional doctrine to consult that told them what the Fourteenth Amendment required.

Similar to the benefit of limiting judicial discretion, facilitating judicial administration is a very real good but is only one among many considerations that informs constitutional doctrine. A single rule applicable to all governmental actions would be the simplest to administer, but it would come at too great a cost to concerns of fairness, democracy, and so forth. For this reason, the pragmatic consideration of judicial administration does not support a categorical rule of One-SizeFits-All. On the other hand, it does strongly counsel against wholly jettisoning the One-Size-Fits-All framework.

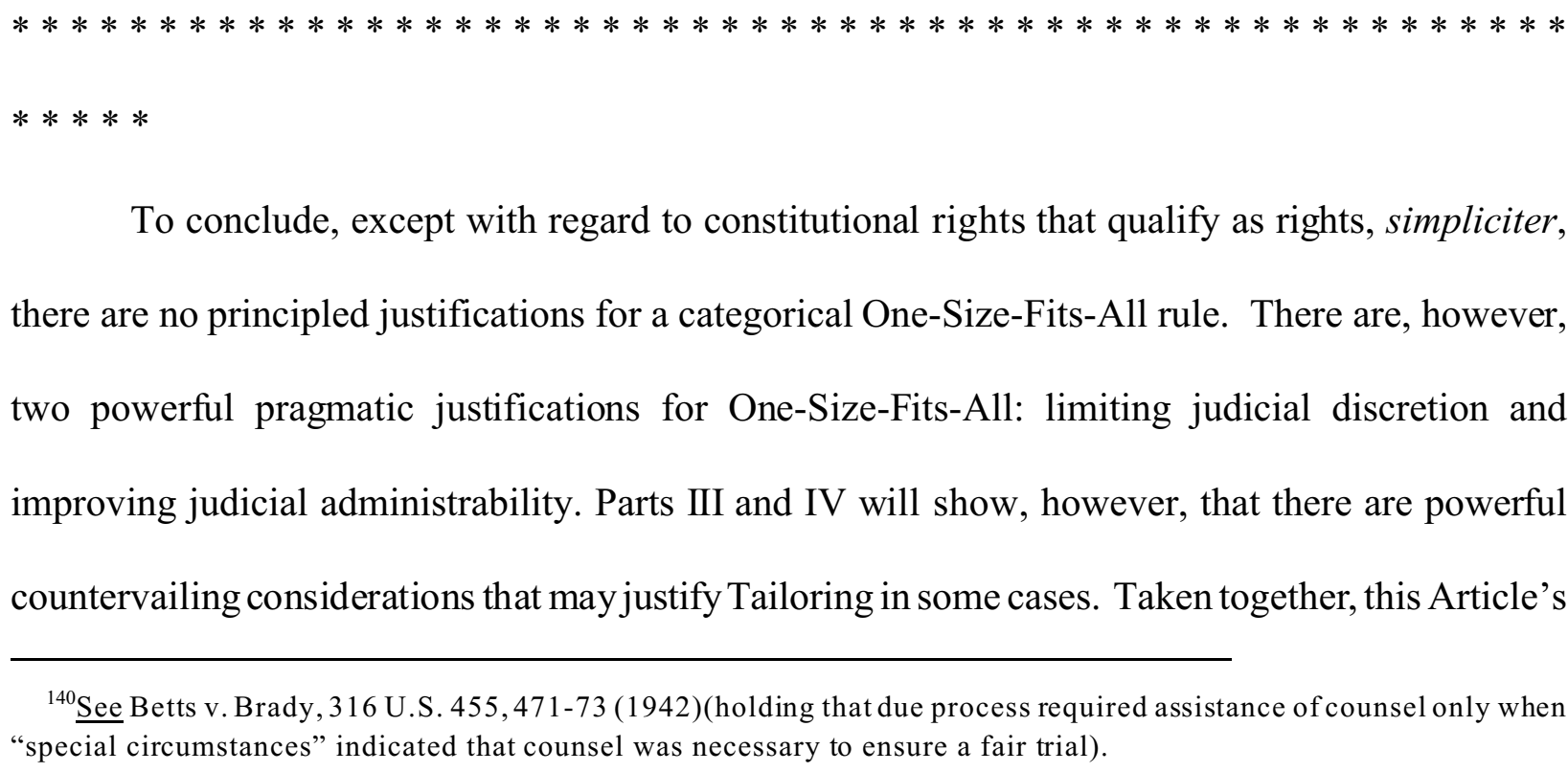


analysis suggests that contemporary doctrine should be modified as follows: today's One-Size-FitsAll doctrine should be downgraded from a categorical requirement to a rebuttable presumption.

III. A Quasi-Precedential Argument: That Tailoring is Not Unknown to American JURISPRUDENCE

Though One-Size-Fits-All is the dominant doctrinal paradigm today, Tailoring is not absent from American jurisprudence. Tailoring has been advanced by Justices Holmes, Jackson, Harlan, Fortas, Powell, Rehnquist, Stevens, Ginsburg, and Thomas. Moreover, several contemporary constitutional doctrines reflect the logic of Tailoring, though they are not typically conceptualized in that way. Further, a very recent decision of the Court was decided on a rationale that reflects the institution-sensitive logic that underwrites Tailoring. Finally, many statutory rules vary in their application depending upon the level of government that is being regulated. The fact that Tailoring already is part of our juridical landscape should cushion concern about this Article's argument: the quasi-precedent for Tailoring makes clear that the Article does not seek to introduce a wholly foreign element of constitutional analysis, but instead advocates a willingness to expanding a methodology already present in American law.

A. Early Influential Support for Tailoring. Though the federal government and the States generally were subject to different constitutional limitations during the era of Fundamental Fairness, the opinions in those cases did not generate particularly searching rationales for the differential treatment as between the federal and state governments. One-Size-Fits-All treatment was not then deemed to be a serious option on account of the fact that the federal and state governments were deemed to be governed by different constitutional language. Virtually all cases decided during the 
Fundamental Fairness era accordingly are not examples of Tailoring.

However, even during the heyday of Fundamental Fairness, the Court utilized an approach virtually indistinguishable from "selective and undifferentiated" incorporation vis-a-vis many First Amendment guarantees. ${ }^{141}$ One-Size-Fits-All was a serious doctrinal contender - indeed, it won the day in this context - sparking dissents that generated the most sophisticated judicial expositions to date concerning the logic of Tailoring. Justice Holmes penned one of the first of these in the 1925 case of Gitlow v. People of the State of New York. ${ }^{142}$ The case concerned a free speech challenge to a state statute that criminalized the advocacy of anarchy, and the majority applied the doctrines developed in the federal context without explanation or justification. Justice Holmes criticized this in his dissent, writing as follows:

The general principle of free speech, it seems to me, must be taken to be included in the Fourteenth Amendment, in view of the scope that has been given to the word 'liberty' as there used, although perhaps it may be accepted with a somewhat larger latitude of interpretation than is allowed to Congress by the sweeping language that governs or ought to govern the laws of the United States. ${ }^{143}$

This text-based argument was all that Holmes had to say on the matter, but the message was clear: the principle of free speech might apply differently to the States than it applies to the federal government. $^{144}$

\footnotetext{
${ }^{141}$ See supra note 72 .

${ }^{142} 268$ U.S. 652 (1925).

${ }^{143}$ Id. at 672 (Holmes, J., dissenting).

${ }^{144}$ Interestingly, in a takings case decided three years before Gitlow that was written by Justice Holmes, Holmes "drew no distinction between takings by state and federal governments." Israel, Selective Incorporation, supra note 51 , at 286 \& n. 264 (discussing Pennsylvania Coal Co. v. Mahon, 260 U.S. 393 (1922)). Nor did Holmes explain why he was willing to treat the state and federal governments interchangeably in Mahon. See Mahon, 260 U.S. at 415 . There are several possible explanations as to why Holmes took divergent approaches with takings and free speech. Perhaps he had a theory that justified different treatment of the two. Perhaps the majority for whom he was writing in $\underline{\text { Mahon }}$ demanded this approach. Or perhaps it was not clear to him in the earlier opinion of Mahon that case law from the federal context need not necessarily seamlessly transfer over to the States. I shall not pursue these possibilities further here.
} 
The next significant discussion of Tailoring appears in Justice Jackson's dissent in Beauharnais v. People of the State of Illinois, ${ }^{145}$ which famously upheld a State's group libel statute. Jackson's analysis focused on the different institutional characteristics of the federal and state governments and hence works well with a right-against-rule conception of constitutional rights. Jackson argued that the state and federal governments are meaningfully different in respect of determining what activities are constitutionally permitted to each: "The inappropriateness of a single standard for restricting State and Nation is indicated by the disparity between their functions and duties in relation to those freedoms." ${ }^{146} \mathrm{He}$ then proceeded to explain why the federal and state governments are differently situated as regards the regulation of libel:

Criminality of defamation is predicated upon power either to protect the private right to enjoy integrity of reputation or the public right to tranquility. Neither of these are objects of federal cognizance except when necessary to the accomplishment of some delegated power .... When the Federal Government puts liberty of press on one scale, it has a very limited duty to personal reputation or local tranquility to weigh against it in the other. But state action affecting speech or press can and should be weighed against and reconciled with these conflicting social interests. ${ }^{147}$

These differences led Jackson to conclude that the First Amendment's free speech guarantee should be Tailored to the the federal and state governments:

For these reasons I should not, unless clearly required, confirm to the Federal Government such latitude as I think a State reasonably may require for orderly government of its manifold concerns. The converse of the proposition is that I would not limit the power of the State with the severity appropriately prescribed for federal power. ${ }^{148}$

Justice Harlan was the next member of the Court to offer a full-blown defense of Tailoring (or, as he called it, opposition to "jot-for-jot" incorporation of the Bill of Rights ${ }^{149}$ ). His position was

\footnotetext{
${ }^{145} 343$ U.S. 250 (1952).

${ }^{146} \underline{\text { Id. }}$ at 294 (Jackson, J., dissenting).

${ }^{147} \underline{\mathrm{Id}}$.

${ }^{148} \underline{\text { Id. }}$. at 294-95 (Jackson, J., dissenting) (emphasis supplied).

${ }^{149}$ See Duncan v. Louisiana, 391 U.S. 145, 181 (1968) (Harlan, J., dissenting).
} 
developed over numerous dissenting opinions. ${ }^{150}$ Roth $v$. United States ${ }^{151}$ contains one of his clearest expositions of Tailoring, and has been relied upon by many subsequent Supreme Court Justices. ${ }^{152}$ The ideas developed there are not appreciably different from Justice Jackson's approach in Beauharnais: Harlan argued that the state and federal governments have different substantive powers and interests, and therefore that "[w]hether a particular limitation on speech or press is to be upheld because it subserves a paramount governmental interest must, to a large extent, I think, depend on whether that government has, under the Constitution, a direct substantive interest, that is, the power to act, in the particular area involved." 153

Harlan advanced two additional justifications for Tailoring in his other dissenting and concurring opinions on the subject. First, in the spirit of Justice Brandeis's New State Ice dissent, ${ }^{154}$ Justice Harlan praised the fact that each State can serve as an independent "experimental social laborator[y]" that can experiment with "novel techniques of social control." 155 Harlan thought that there was an "immense advantage" of having "separate centers for such experimentation," and argued that there was "no overwhelming danger to our freedom to experiment" so long as there was "no uniform nation-wide" regulation. ${ }^{156}$ Justice Harlan argued that the possibility of

\footnotetext{
${ }^{150}$ For a sample of Justice Harlan's Tailoring opinions in the criminal context, see Duncan v. State of Louisiana, 391 U.S. 145, 171 (1968) (Harlan, J., dissenting); Mapp v. Ohio, 367 U.S. 643, 672 (Harlan, J., dissenting); Ker v. State of California, 374 U.S. 23, 44 (Harlan, J., concurring); Malloy v. Hogan, 378 U.S. 1, 14 (1964) (Harlan, J., dissenting); Pointer v. State of Texas, 380 U.S. 400, 408 (1965) (Harlan, J., concurring); Griffin v. State of California, 380 U.S. 609 , 615 (Harlan, J., concurring).

${ }^{151}$ See Roth v. United States, 354 U.S. 476, 505 (1957) (Harlan, J., dissenting).

${ }^{152}$ See, e.g., Crist v. Bretz, 437 U.S. 28, $52-53$ (1978) (Powell, J., dissenting) (relying on Harlan's opinion in Duncan v. State of Louisiana, 391 U.S. 145, 171 (1968) (Harlan, J., dissenting)); Buckley v. Valeo, 424 U.S. 1, 293 (1976) (Rehnquist, J., concurring) (same).

${ }^{153} \underline{\text { See }} \underline{\text { Roth, }} 354$ U.S. at 504-05. For Justice Harlan's full quotation, see infra at p. 112.

${ }^{154}$ New State Ice Co. v. Liebmann, 285 U.S. 262, 311 (1932) (Brandeis, J., dissenting).

${ }^{155} \underline{\text { Roth}}, 354$ U.S. at 505.

${ }^{156}$ Id. at $505-06$ (arguing that states should have broader powers to prohibit distribution of books than the federal government).
} 
experimentation, in the absence of severe risk due to the fact that other States can be expected to legislate differently, was a reason to treat State legislation differently than federal legislation for purposes of constitutional analysis. ${ }^{157}$

Conversely, Justice Harlan argued that there are far greater "dangers to free thought and expression ... if the Federal Government imposes a blanket ban over the nation on such a book" than if a State does because a federal would bar all American citizens from accessing the proscribed publication. ${ }^{158}$ A federal ban also destroys " $[\mathrm{t}]$ he prerogative of the States to differ on their ideas of morality." $" 159$ The greater dangers inherent in federal regulation accordingly justify a constitutional regime under which the federal government would be subject to more stringent constitutional limitations than States, meaning that States could ban materials that the federal government could not in Harlan's view.

These opinions of Holmes, Jackson, and Harlan are the most sophisticated treatments of Tailoring in the judicial corpus, and numerous Justices have drawn upon them in their advocacy of Tailoring particular constitutional doctrines. For example, in a concurring opinion in Duncan $v$. Louisiana ${ }^{160}$ Justice Fortas cited to Harlan's opinions when writing that "[n] either logic nor history nor the intent of the draftsmen of the Fourteenth Amendment can possibly be said to require that the Sixth Amendment or its jury trial provision be applied to the States together with the total gloss that this Court's decisions have supplied."161 Justice Powell similarly relied heavily on Harlan's arguments when he advocated Tailoring the Double Jeopardy Clause and several Sixth Amendment

\footnotetext{
${ }^{157} \underline{\text { Id. }}$.

${ }^{158} \underline{\text { Id. }}$. at 506.

${ }^{159}$ Id.

160391 U.S. 145 (1968).

${ }^{161}$ Id. at 213 (Fortas, J., concurring).
} 
protections. ${ }^{162}$ Justice Rehnquist relied on Homes, Jackson, and Harlan when he argued in a concurrence in Buckleyv. Valeo ${ }^{163}$ that "not all the strictures which the First Amendment imposes upon Congress are carried over against the States by the Fourteenth Amendment, but rather it is only the 'general principle' of free speech ... that the latter incorporates." ${ }^{.164}$ Justice Thomas relied on the same set of Justices in his concurring opinion in the Zelman decision, ${ }^{165}$ where he wrote that "in the context of the Establishment Clause, it may well be that state action should be evaluated on different terms than similar action by the Federal Government." ${ }^{166}$

Neither Justices Fortas nor Powell nor Rehnquist nor Thomas have advanced the theory behind Tailoring; their opinions are wholly derivative of the arguments developed by Justices Holmes, Jackson, and Harlan. But these opinions of Fortas, Powell, Rehnquist, and Thomas demonstrate that Tailoring's logic is not foreign to modern Supreme Court justices.

\section{B. Contemporary Constitutional Decisions That Reflect the Logic of Tailoring. There are} other recent cases in which Justices have accepted the logic of Tailoring. Some are majority decisions. Several of these decisions have won the support of liberal Justices. This shows that Tailoring is not just a tool of conservative jurisprudence, notwithstanding the fact that to date

\footnotetext{
${ }^{162}$ See Crist v. Bretz, 437 U.S. 28, 52-53 (1978) (Powell, J., joined by Burger, C.J., and Rehnquist, J., dissenting) ("Even if I were to conclude that the Fifth Amendment - merely by virtue of long, unreasoned acceptance - required attachment of jeopardy at the swearing of the jury, I would not hold that the Fourteenth Amendment necessarily imposes that requirement upon the States. This issue would turn on the answer to the question whether jeopardy's attachment at that point is fundamental to the guarantees of the Double Jeopardy Clause. ); Johnson v. Louisiana, 406 U.S. 366,371 (1972) (Powell, J., concurring) (rejecting the premise "that the concept of jury trial, as applicable to the States under the Fourteenth Amendment, must be identical in every detail to the concept required in federal courts by the Sixth Amendment."); see also Apodaca v. Oregon, 406 U.S. 404 (Powell, J., concurring in judgment) (same); Ludwig v. Massachusetts, 427 U.S. 618 (1976) (Powell, J., concurring) (same).

${ }^{163} 424$ U.S. 1, 291 (1976) (Rehnquist, J., concurring).

${ }^{164} \underline{I d}$. Justice Rehnquist quotes extensively from Holmes, Jackson and Holmes to support this proposition. $\underline{\text { See }} \underline{\mathrm{id}}$. at $292-93$.

${ }^{165} 122$ S.Ct. 2460 (2002).

${ }^{166}$ Id. at 2481 (Thomas, J., concurring).
} 
Tailoring has been advocated primarily by right-leaning Justices.

A tantalizingly simple lesson emerges from a study of the instances where individual Justices or the Court has been willing to Size. Tailoring is invoked when Justices believe that two levels of government are sufficiently different to merit different constitutional treatment. To be sure, the Court has not identified a determinate set of principles to identify when sufficient differences are present. Nevertheless, the practical, functional analysis that leads to judicial willingness to engage in Tailoring is black letter predicate for Part IV's examination of generic reasons for treating the different levels of government differently.

1. Federal Affirmative Action Programs. One of the most sustained recent defenses of Tailoring can be found in Justice Stevens' dissent in the case of Adarand Constructors, Inc. v. Pena. ${ }^{167}$ The majority opinion in Adarand replaced a rare instance of Tailoring with a One-Size-FitsAll approach. Prior to Adarand, state affirmative action programs were subject to strict scrutiny ${ }^{168}$ whereas federal programs only had to satisfy intermediate scrutiny under the rule announced in Metro Broadcasting. ${ }^{169}$ The Adarand majority identified what it labeled the principle of "congruence" - the requirement that "[e]qual protection analysis in the Fifth Amendment area is the same as that under the Fourteenth Amendment" ${ }^{p 170}$ - to reverse Metro Broadcasting. ${ }^{171}$ In its place, Adarand established that federal and state affirmative action programs are to be analyzed under identical legal standards. ${ }^{172}$

\footnotetext{
${ }^{167} 515$ U.S. 200 (1995).

${ }^{168}$ This was the rule announced in Richmond v. J.A. Croson Co., 488 U.S. 469 (1989).

${ }^{169}$ See Metro Broadcasting Inc. v. FCC, 497 U.S. 547, 564-65 (1990).

${ }^{170}$ Adarand, 515 U.S. at 224 (quoting Buckley v. Valeo, 424 U.S. 1, 93 (1976)).

${ }^{171}$ Adarand, 515 U.S. at 227.

${ }^{172}$ Id. ("Accordingly, we hold today that all racial classifications, imposed by whatever federal, state, or local governmental actor, must be analyzed by a reviewing court under strict scrutiny.").
} 
The principle of "congruence" announced in Adarand accordingly is an example of OneSize-Fits-All in the particular context of equal protection doctrine. Justice Stevens, joined by Justice Ginsburg, dissented with regard to the principle of congruence:

The Court's concept of 'congruence' assumes that there is no significant difference between a decision by the Congress of the United States to adopt an affirmative-action program and such a decision by a State or a municipality. In my opinion that assumption is untenable. It ignores important practical and legal differences between federal and state or local decisionmakers. ${ }^{173}$

The majority in Adarand relied exclusively on a quotation from the 1976 case of Buckley v. Valeo in support of its principle of congruence, ${ }^{174}$ but Justice Stevens demonstrated that the majority ignored many subsequent decisions in which the Court had found that there were constitutionally relevant differences between the federal and sub-federal polities with regard to the application of equal protection principles. ${ }^{175}$ The Adarand majority was content to rely on what fairness suggests was insufficient precedent - it was insufficient because there was more recent countervailing precedent - and did not feel it necessary to engage in a substantive exchange of views with Justice Stevens' several arguments as to why the federal and sub-federal governments were sufficiently different so as to justify subjecting them to different legal tests.

Justice Stevens provided three arguments against the One-Size-Fits-All approach of the "congruence" doctrine. First, as a purely textual matter, the federal government's "legislative powers concerning matters of race were explicitly enhanced by the Fourteenth Amendment. ${ }^{1176}$ Stevens then provided two arguments as to why the Congress has a "special institutional competence" not enjoyed by the sub-federal polities with regard to matters of race. ${ }^{177}$ Quoting from Scalia's separate opinion

\footnotetext{
${ }^{173}$ Id. at 249 (Stevens, J., dissenting).

${ }^{174}$ Adarand, 515 U.S. at 224 (quoting Buckley v. Valeo, 424 U.S. 1, 93 (1976)).

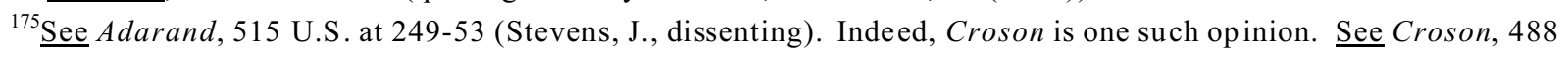
U.S. at 737 (Scalia, J., concurring).

${ }^{176}$ Id. at 250.

${ }^{177}$ Id. at 249-50 (internal quotation omitted).
} 
in the Croson case, Stevens first explained Congress's special capability by drawing on Madison's famous discussion of factions from Federalist No. 10:

[R]acial discrimination against any group finds a more ready expression at the state and local than at the federal level. To the children of the Founding Fathers, this should come as no surprise. An acute awareness of the heightened danger of oppression from political factions in small, rather than large, political units dates to the very beginning of our national history. ${ }^{178}$

It is sensible to impose greater review on sub-federal racial classifications than federal classifications, Stevens argued, because of the greater potential for discrimination that exists at the sub-federal level. ${ }^{179}$ Third, Stevens explained that "greater deference [should be given] to the National Legislature than to a local lawmaking body [because] federal affirmative-action programs represent the will of our entire Nation's elected representatives, whereas a state or local program may have an impact on nonresident entities who played no part in the decision to enact it." ${ }^{\prime 180}$

Justice Stevens provided one additional argument on behalf of Tailoring in his Adarand dissent that did not have any application to the issue in the case. Stevens quoted dictum from the majority opinion he authored in Hampton v. Mow Sun Wong ${ }^{181}$ to the effect that "the two protections [the Fifth and Fourteenth Amendments' due process clauses] are not always coextensive. Not only does the language of the two Amendments differ, but more importantly, there may be overriding

\footnotetext{
${ }^{178}$ Id. at 251(quoting Croson, 488 U.S. at 737 (Scalia, J., concurring). Scalia (and Stevens) thereafter quoted from the Federalist No. 10: "The smaller the society, the fewer probably will be the distinct parties and interests composing it; the fewer the distinct parties and interests, the more frequently will a majority be found of the same party, and the smaller the number of individuals composing a majority, and the smaller the compass within which they are placed, the more easily will they concert and execute their plan of oppression. Extend the sphere and you take in a greater variety of parties and interests; you make it less probable that a majority of the whole will have a common motive to invade the rights of other citizens..." Adarand, 515 U.S. at 251 (Stevens, J., dissenting) (emphasis supplied).

${ }^{179} \underline{\text { Id. at }} 250$ )(Stevens, J., dissenting).

${ }^{180}$ Adarand, 515 U.S. at 252 (Stevens, J., dissenting). This is a representation-reinforcement type justification of the sort developed by Professor Ely. See John Hart Ely, Democracy And Distrust and discussed infra at Part IV.A.1(a).

${ }^{181} 426$ U.S. 88, 100 (1976).
} 
national interests which justify selective federal legislation that would be unacceptable for an individual State."182 This rationale is quite close to the justification for Tailoring that was offered by Justices Jackson and Harlan. ${ }^{183}$

I do not mean to suggest that Justice Stevens' conclusion necessarily was correct in Adarand. It does seem, however, that the precedential and functional arguments he advanced for treating the federal and state governments differently from the federal government as regards affirmative-action programs merited a serious response - something the majority opinion neglected to provide.

2. Property-based Franchise. Continuing with this Article's review of contemporary examples of Tailoring, let us turn to the guarantee of equal protection that prohibits both the federal government and States from conditioning a citizen's right to vote on property ownership under the principle of one-person, one-vote. ${ }^{184}$ The Court held in Ball v. James, ${ }^{185}$ however, that there are types of local government that while subject to the Fourteenth Amendment's equal protection clause ${ }^{186}$ are not barred from utilizing a property-based franchise. This is true, for

\footnotetext{
${ }^{182}$ Adarand, 515 U.S. at 253 \& n. 8 (Stevens, J., dissenting), quoting Hampton, 426 U.S. at 100. The remainder of the quotation reads as follows: "On the other hand, when a federal rule is applicable to only a limited territory, such as the District of Columbia, or an insular possession, and when there is no special national interest involved, the Due Process Clause has been construed as having the same significance as the Equal Protection Clause." Adarand, 515 U.S. at 253 \& n. 8 (Stevens, J., dissenting), quoting Hampton, 426 U.S. at 100. While this generally is descriptively true, this Article suggests an alternative justification for Tailoring that would support Tailoring in a broader range of circumstances. To be completely clear, the point of Part II of this Article is to identify some instances of Tailoring in contemporary constitutional law not for the purpose of suggesting that Tailoring should be limited to like circumstances, but to show that Tailoring is not completely unknown to our constitutional jurisprudence.

${ }^{183}$ See supra Part III(A). Justice Stevens, however, did not refer to those opinions, nor that of Holmes, in the course of his dissent in Adarand or his opinion for the Court in Hampton. Perhaps Justice Stevens did not believe that opinions concerning incorporation were relevant to the reverse incorp oration issues raised in Hampton and Adarand. The analysis provided in this Article, however, suggests that the incorporation issues addressed by Holmes, Jackson, and Harlin and the reverse incorporation questions raise the same conc eptual question: are the different lvels of government sufficiently different to justify Tailoring? It stands to reason that the case law found in one context may be illuminating to the other. Part IV of this Article shows this to be the case.

${ }^{184}$ See Reynolds v. Sims, 377 U.S. 533 (1964).

${ }^{185} 451$ U.S. 355 (1981). This was not the first time the Court had so held. See Salyer Land Co. v. Tulare Lake Basin Water Storage District, 410 U.S. 719 (1973).

${ }^{186}$ See Ball, 45 U.S. at 371.
} 
example, of water reclamation districts ${ }^{187}$ and business improvement districts. ${ }^{188}$

In this circumstance, the Tailoring occurs as between "general" state and federal governments, on the one hand, and "special-purpose unit[s] of government," on the other. ${ }^{189}$ With respect to our model of constitutional doctrine, deviation occurs at levels 3 and 4, such that although

$$
\begin{aligned}
& 1 . \mathrm{S}_{\text {(general government) }}=1 . \mathrm{S}_{\text {(special-purpose government) }} \text { and } \\
& 2 . \mathrm{S}_{\text {(general government) }}=2 . \mathrm{S}_{\text {(special-purpose government) }} \text {, }
\end{aligned}
$$

it is the case that

$$
\begin{gathered}
3 . \mathrm{S}_{\text {(general government) }} \neq 3 . \mathrm{S}_{\text {(special-purpose government) }} \text {, and } \\
4 . \mathrm{S}_{\text {(general government) }} \neq 4 . \mathrm{S}_{\text {(special-purpose government) }} .
\end{gathered}
$$

This is an example of Tailoring: although the Fourteenth Amendment's equal protection clause applies to both general and special-purpose governments $\left(1 . S_{\text {(general government) }}=1 . S_{(\text {special-purpose government) }}\right)$, it applies differently to each. More specifically, $3 . \mathrm{S}_{\text {(general government) }}$ is heightened scrutiny, ${ }^{190}$ which under 4. $\mathrm{S}_{\text {(general government) }}$ includes the requirement of one-person, one-vote. By contrast, 3.S $\mathrm{S}_{\text {(special-purpose }}$ government) is the far more deferential requirement that the voting scheme "bear[] a reasonable relationship to its statutory objectives." ${ }^{\prime 191}$ The one-person, one-vote requirement simply is not part of 4.S $\mathrm{S}_{\text {(special-purpose government). }}$ All that is necessary under $4 . \mathrm{S}_{\text {(special-purpose government) }}$ is a showing that "the effect of the entity's operations on [those with the right to vote] was disproportionately greater than the effect on those seeking the vote."

The Court justified its decision to Tailor equal protection on the basis of the different institutional characters of the two types of governments. The Court concluded that "special-purpose

\footnotetext{
${ }^{187} \underline{\text { See }} \underline{\mathrm{id}}$.

${ }^{188}$ See, e.g., Lane v. Town of Oyster Bay, 603 N.Y.S.2d 53, 54 (N.Y. App. 1993).

${ }^{189}$ See Ball, 451 U.S. at 362-63.

${ }^{190}$ See Hill v. Stone, 421 U.S. 289, 297 (1975).

${ }^{191}$ Ball, 451 U.S. at 371.

${ }^{192}$ Id. at 371 .
} 
units" of government are sufficiently different from "general" governments to merit different constitutional treatment. Because special-purpose units of government "affect[] definable groups of constituents more than other constituents" it is permissible to allow only those primarily affected to vote. ${ }^{193}$ To be sure, it can be exceedingly difficult to distinguish these two categories; Ball in fact is one such case. ${ }^{194}$ The important point is that there is precedent supporting the principle that identical constitutional language may apply differently to two levels of State government when each level is sufficiently different to merit differential treatment.

3. Separation-of-Powers Tailoring. The Court recently adopted the same institutionally sensitive analysis with regard to an analogous issue that might be dubbed "separation of powers" Tailoring: the question of whether constitutional limitations on the legislature seamlessly transfer to the judiciary. The defendant in the 2001 case of Rogers $v$. Tennessee, ${ }^{195}$ who had been convicted of second-degree murder, appealed on the basis that the victim had died more than a year and a day after the defendant had stabbed him. At the time of the stabbing Tennessee unquestionably had a common-law "year and a day rule," which precluded conviction of murder unless a victim had died by the defendant's act within a year and a day of the act. ${ }^{196}$ The Supreme Court of Tennessee abolished the "year and a day rule" and applied a new rule to the defendant, ${ }^{197}$ upholding the conviction despite the fact that 15 months had elapsed between infliction of the stab wounds and the victim's death. ${ }^{198}$

The question in Rogers was whether such retroactivity was constitutional. The Ex Post Facto

\footnotetext{
${ }^{193}$ Id. at 363.

${ }^{194}$ The dissent does a good job of explaining why. See id. at 374, 377-85 (White, J., dissenting).

${ }^{195} 532$ U.S. 451 (2001).

${ }^{196}$ Id. at 453 .

${ }^{197} \underline{\mathrm{Id}}$.

${ }^{198}$ Id. at 454.
} 
Clause by its terms applies only to State legislatures, ${ }^{199}$ and the Rogers Court assumed that the Clause would have been violated if the Tennessee legislature had abolished the year and a day rule after the defendant had stabbed his victim. ${ }^{200}$ Language from a 1964 Supreme Court decision declared that state legislatures and state judiciaries should be treated no differently in this regard; the Court in Bouie v. City of Columbia ${ }^{201}$ stated that "[i]f a state legislature is barred by the Ex Post Facto Clause from passing ... a law, it must follow that a State Supreme Court is barred by the Due Process Clause from achieving precisely the same result by judicial construction." ${ }^{202}$ Bouie hence adopted a One-Size-Fits-All approach to separation of powers as regards the retroactivity of criminal rules.

Notwithstanding Bouie, the majority in Rogers opted for a rule that treated the state legislature and judiciary divergently. ${ }^{203}$ The Rogers Court explicitly rejected the One-Size-Fits-All approach, referring to it using Justice Harlan's "jot-for-jot" terminology and stating that "nowhere in the [Bouie] opinion did we go so far as to incorporate jot-for-jot the specific categories of Calder into due process limitations on the retroactive application of judicial decisions." ${ }^{204}$ The jurisprudential model developed earlier in the Article facilitates an appreciation of precisely where

\footnotetext{
${ }^{199}$ See U.S. CONST. ART. I, §10, CL. 1 (“[n]o State shall . . p pass any ex post facto Law.”).

${ }^{200} \underline{\text { Rogers }}, 532$ U.S. at 458; $\underline{\text { see }} \underline{\text { also }} \underline{\text { id. }}$. at 462 (restating, and not disputing, Justice Scalia's contention that "there is no doubt that the Ex Post Facto Clause would have prohibited a legislative decision identical to the Tennessee court's decision here").

${ }^{201} 378$ U.S. 347 (1964).

${ }^{202}$ Id. at 353-54.

${ }^{203}$ There was a most unusual split in the Rogers decision. Justice O 'Connor's majority opinion was joined by Chief Justice Rehnquist and Justices Kennedy, Ginsburg, and Souter. Justice Scalia wrote a dissent that was joined by Justices Stevens and Thomas and by Justice Breyer in part. Justice Breyer also penned a separate dissent. $\underline{\text { See }} \underline{\mathrm{id}}$. at 451.

${ }^{204} \underline{\text { Rogers }}, 532$ U.S. at 459 . The Rogers majority was technically correct to the extent that the Bouie Court's language was dictum, as the majority held. Id. On the other hand, one can hardly imagine a clearer signal of the Court's contemporary understanding of a related issue than what can be found in Bouie. Moreover, Justice Scalia's dissent

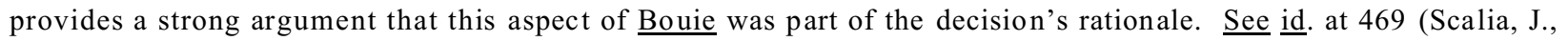
dissenting). In any event, how Bouie's language is best characterized is not relevant to the wisdom of the Court's methodology in Rogers but instead determines whether the majority followed or overruled precedent - surely an important question, but not one that will receive further attention here.
} 
the doctrines deviate. To begin, there were differences at Step 1; the Court noted that while the Ex Post Facto Clause applied to state legislatures, the state judiciary was limited only by the Fourteenth Amendment's due process requirement. ${ }^{205}$ With regard to Step 2, the Rogers Court expressly concluded that both the Ex Post Facto Clause and due process nevertheless shared the identical Goal, stating that it was "undoubtedly correct" that "the Due Process and Ex Post Facto Clauses safeguard common interests - in particular, the interests in fundamental fairness (through notice and fair warning) and the prevention of the arbitrary and vindictive use of the laws." ${ }^{206}$ Deviation also occurred at steps 3 and 4 in the doctrine, the levels of Standard and rulified Standard: while the legislature is precluded from making any change in the criminal law subsequent to the criminal act that works to the defendant's disadvantage, ${ }^{207}$ the judiciary is prevented only from making unforeseeable changes. ${ }^{208}$ To graphically summarize,

$$
\begin{aligned}
1 . S_{(\text {legislature) }} & \neq 1 . S_{\text {(judiciary), }} \\
2 . S_{\text {(legislature) }} & =2 . S_{\text {(udiciary) }}, \\
3 . S_{\text {(legislature) }} & \neq 3 . S_{\text {(uduciciary) }} \text { and } \\
4 . S_{(\text {legislature) }} & \neq 4 . S_{\text {(undiciary) }} .
\end{aligned}
$$

The Rogers Court then held that because the year and a day rule was "widely viewed as an outdated relic of the common law," it "was not unexpected and indefensible" for the Tennessee Supreme Court to abolish it. ${ }^{209}$ The Court accordingly upheld the defendant's conviction. ${ }^{210}$

The Rogers majority elected to treat the legislature and judiciary differently - what might be

\footnotetext{
${ }^{205} \underline{\text { See }} \underline{\text { Rogers, }}, 432$ U.S. at 460 ("The Ex Post Facto Clause, by its own terms, does not apply to courts. Extending the Clause to courts through the rubric of due process thus would circumvent the clear constitutional text.").

${ }^{206}$ Id.

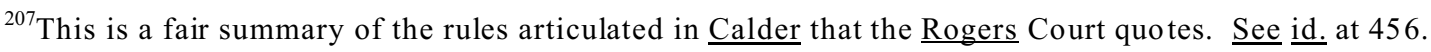

${ }^{208}$ Id. at 462 (judiciary can make changes to common law unless it is "unexpected and indefensible by reference to the law which had been expressed prior to the conduct in issue.").

${ }^{209}$ Id. at 462-63.

${ }^{210} \underline{\text { Id. }}$ at 467 .
} 
termed "Tailoring" along the dimension of separation of powers rather than federalism - due to the "important institutional and contextual differences between legislating, on the one hand, and common law decisionmaking, on the other." ${ }^{211}$ The Court provided two reasons why the two institutions were meaningfully different for constitutional purposes. First, constitutional constraints on the judiciary could be less strict because courts are less susceptible to "political influences and pressures" since they only "constru[e] existing law in actual litigation." 12 Second, because the judiciary is responsible for the case-by-case development of the law, Calder's absolute brake on retroactivity would "unduly impair the incremental and reasoned development of precedent that is the foundation of the common law system." ${ }^{213}$ Whether or not one agrees with the Rogers Court's ultimate disposition, the following methodological conclusion is incontestable: the Court justified its holding by carefully considering the institutional character of each governmental entity. The Court refused to reflexively import doctrines developed in the legislative context to the judiciary, notwithstanding dictum in the Bouie decision that said such a One-Size-Fits-All approach was appropriate.

The Rogers Court analysis, and its treatment of Bouie, are precedent for the methodology advocated in this Article. Bouie was decided in 1964, in the midst of the Court's ongoing rejection of "fundamental fairness" and embrace of selective incorporation. In that era, the conclusion that a constitutional guarantee was incorporated invariably was followed by the unexplained determination that all doctrines developed in the federal context naturally applied to the States in equal measure. ${ }^{214}$ Bouie is part of that historical context. Rogers is a more reflective analysis of

\footnotetext{
${ }^{211}$ Id. at 460.

${ }^{212} \underline{\text { Id. }}$. at 461 .

${ }^{213} \underline{\mathrm{Id}}$.

${ }^{214}$ See supra Part I.B(3).
} 
what precisely is imported from one context to another during the process of incorporation. The context- sensitive institutional analysis utilized by the Rogers majority is precisely the sort of approach that this Article suggests is appropriate in the more usual situation of "federalism" incorporation.

To be sure, the Rogers Court's institution-sensitive analysis runs up against far less precedent than Tailoring in the federalism context would, for there have been very few cases that have considered how constitutional principles transfer across the different branches of government. The policy reasons for engaging in institutional-sensitive analysis, however, are identical in both "federalism" and "separation of powers" incorporation: two institutions might be sufficiently different to justify differential treatment as a constitutional matter. While adopting the functional analysis of the Rogers variety in the context of "federalism" incorporation certainly would require that the Court revisit a methodology of One-Size-Fits-All that it has applied and discussed in many decisions, this precedent should not foreclose the possibility of Tailoring. The justifications for a categorical One-Size-Fits-All approach are deficient (Part II), and there are strong policy reasons to conclude that Tailoring may be advantageous (Part IV). Under these circumstances, the Court's recent willingness to utilize institutionally-sensitive analysis in Rogers is instructive to "federalism" incorporation. Precedent can be honored without ignoring Tailoring's potential benefits by downgrading the categorical One-Size-Fits-All approach that characterizes contemporary doctrine to a rebuttable presumption that could take account of the varying institutional characteristics of the different levels of government.

4. Dormant Commerce Clause. Dormant commerce clause doctrine also fits the 
Tailoring paradigm. Dormant commerce clause limitations apply only to the States, not Congress. ${ }^{215}$

Consequently, Congress can enact protectionist legislation whereas States may not. ${ }^{216}$ This differential treatment of the States and the federal governments thus fits the paradigm of Tailoring.

It could be argued, however, that dormant commerce clause doctrine is not an example of Tailoring. The dormant commerce clause does not illustrate a judicial determination to treat the States and federal governments differently, some might say, because the doctrine applies only where Congress has not acted. ${ }^{217}$ The dormant commerce clause only limits the States and accordingly does not fit the Tailoring paradigm.

For some readers, this formal argument might definitively establish Tailoring's irrelevance to the dormant commerce clause. I view the matter differently. The mere fact that constitutional language addresses only one level or branch of government has not prevented migration of the constitutional principle to other levels or branches of government. For instance, equal protection principles have been applied to the federal government despite the fact that the equal protection clause by its terms applies only to States, ${ }^{218}$ and retroactivity principles have been applied to the state judiciary despite the fact that the ex post facto clause applies only to state legislatures. ${ }^{219}$ If explicit

\footnotetext{
${ }^{215}$ See Maine v. Taylor, 477 U.S. 131, 138 (1986) ("It is well established that Congress may authorize the States to engage in regulation that the Commerce Clause would otherwise forbid.”); see also New York v. United States, 505 U.S. 144 (1992) (same).

${ }^{216}$ See The statement above in text simplifies matters a bit. There is a virtually per se rule against protectionist state legislation, not an absolute prohibition. See Maine v. Taylor, 477 U.S. 131 (1986). There is no limitation as regards protectionism whatsoever, however, on federal legislation. See id. at 138.

${ }^{217}$ See Mark D. Rosen, Extraterritoriality and Political Heterogeneity in American Federalism, 150 U. PA. L. REV. 855, 921 (2002) [hereinafter "Extraterritoriality and Federalism"]. This has been the case since the doctrine's early days. See Wilson v. The Black Bird Creek Marsh Co., 27 U.S. (2 Pet.) 245 (1829) (Marshall, C.J.)(the question of whether a state statute is "repugnant to the power to regulate commerce in its dormant state" arises when "congress has passed no" act).

${ }^{218}$ See Bolling v. Sharpe, 347 U.S. 497 (1954).

${ }^{219}$ See Rogers v. Tennessee, 532 U.S. 451 (2001).
} 
constitutional language addressing only a particular level or branch of government does not prevent the export of constitutional principles to other levels or branches, it follows a fortiori that constitutional principles lacking an explicit textual basis in the Constitution, such as those found in dormant commerce clause jurisprudence, in principle could be exported to other levels of government. For instance, many have identified the dormant commerce clause with a principle of non-discrimination, ${ }^{220}$ and it is quite conceivable that some such principle could be applied to acts of Congress.

If this is right, then formal grounds alone cannot explain why dormant commerce clause limitations have not been exported to the federal government. The Court and commentators indeed have provided an explanation that focuses on the different institutional characteristics of federal and state governments. Concerns that are present when states legislate are absent, or at least are far less pronounced, when the Congress acts. The dormant commerce clause "permits Congress to legislate on certain matters of national importance while denying power to the States in this area for fear of undue impact upon out-of-state residents." ${ }^{221}$ The Congress is differently situated than state legislatures vis-a-vis the imposition of costs on unrepresented outsiders because Congress is composed of representatives from all States. ${ }^{22}$

Donald Regan, an influential commentators on the dormant commerce clause, has argued that the doctrine is primarily concerned with guarding against "protectionist" legislation that is designed to "improv[e] the competitive position of in-state economic actors at the expense of their

\footnotetext{
220 See Donald H. Regan, The Supreme Court and State Protectionism: Making Sense of the Dormant Commerce Clause, 84 Mich. L. Rev. 1091 (1986).

${ }^{221}$ Adarand Constructors, Inc. v. Pena, 515 U.S. 200, 252 (1995) (Stevens, J., dissenting). This understanding recalls John Hart Ely's representation-reinforcement theory of judicial review, though Justice Stevens does not cite to Ely. See infra Part IV.A(1).

${ }^{222}$ See Southern Pacific Co. v. Arizona ex rel. Sullivan, 325 U.S. 761, 767-68, n.2 (1945).
} 
out-of-state competitors."223 "Such behavior," Regan argues, "has no place in a genuine political union of any kind" because it is "inconsistent with the very idea of political union." 224 Such protectionist behavior, it has been argued, “expresses a constitutionally impermissible attitude toward the interests of other States in the political union." ${ }^{225}$ To the extent protectionism in this sense is the problem addressed by the dormant commerce clause, an institutional analysis suggests that it is sensible that the doctrine limits only the States. The centrifugal, nation-shattering impulse giving rise to protectionist legislation is far less likely to be found in the halls of the national legislature than in state houses insofar as national legislators are more likely than their state counterparts to keep the national interest in mind. Furthermore, parochial tendencies are less likely to prevail in the national legislature, where the parties who would be injured by protectionism have representatives to protect their interests.

In sum, that dormant commerce clause limitations have not migrated from the States to the federal government is best understood at least partly in institutional terms. The federal and state governments are different in ways that make it unnecessary for there to be dormant commerce clause-type checks on the Congress. As a result, under the dormant commerce, the federal government is permitted to do things that the States cannot - yet another contemporary instance of Tailoring.

\section{Apportionment and other Methods for Enhancing the Political Power of} Numerical Minorities. Many constitutional principles that relate to the weight of each individual's

\footnotetext{
${ }^{223}$ See Elizabeth Anderson and Richard Pildes, Expressive Theories of Law: A General Restatement, 148 U. PA. L. REV. 1503, 1553 (2000)(fairly describing Professor Regan's view that contemporary dormant commerce clause case law is best rationalized as seeking to counter protectionist legislation) [hereinafter "Restatement"].

${ }^{224}$ Regan, Making Sense of the Dormant Commerce Clause, supra note 219, at 1113.

${ }^{225}$ Anderson \& Pildes, Restatement, supra note 222, at 1554.
} 
vote have not migrated from the States to the federal government and visa-versa. The two levels of government accordingly are treated differently under the Constitution and are thus additional contemporary examples of Tailoring.

(a) Area-Based Apportionment. The most significant variation between the federal government and the States concerns the permissibility of apportionment on the basis of criteria that generate voting districts of unequal populations. The United States Senate is apportioned not on a population basis, but on an area-basis. ${ }^{226}$ The Court has held that every State, however, must structure its legislature so that all the members of each house represent substantially the same number of people. ${ }^{227}$ Indeed, the Court struck down a state scheme that apportioned one of its legislative houses on an area-basis akin to the United States Senate. ${ }^{228}$

Area-based apportionment hence is yet another instance where the federal and state governments are treated differently: it is permissible for the federal government, but not the States. Indeed, the scope of the deviation is unusually large. Variation occurs at the first step in doctrinal development: the Court in essence held that the "equal population" aspect of the equal protection principle does not apply to the federal government, despite the fact that virtually all other components of equal protection are reverse incorporated against the federal government.

One might be tempted to conclude that the fact that the federal and state governments are regulated by different constitutional provisions (the States by the equal protection clause, the federal government by Article I, $\S 3$, which creates the U.S. Senate) means that area-based apportionment

\footnotetext{
${ }^{226}$ See U.S. CONST. ART. I, § 3. Each State has two senators, regardless of population. "[T]he ratio of overrepresentation of the least populated state, Wyoming, to the most populous state, California, is just under 70 to 1. ." Robert A. Dahl, How Democratic is the American Constitution? 50 (Yale Univ. Press 2001).

${ }^{227}$ See Reynolds v. Sims, 377 U.S. 533, 90 (1964) (Harlan, J., dissenting) (providing a succinct statement of the Court's holding).

${ }^{228}$ See Reynolds, 377 U.S. at 571-72.
} 
is not an example of Tailoring at all insofar as there is no constitutional principle common to both levels of government that is being Tailored. As explained in relation to the dormant commerce clause, ${ }^{229}$ however, such formal differences alone cannot explain the failure of the constitutional principles to migrate, ${ }^{230}$ for other constitutional principles that by their terms applied to only one level or branch of government have migrated. Other factors accordingly must account for the different treatment of the federal and state governments. The Court repeatedly has rejected the socalled "federal analogy" as being "inapposite and irrelevant to state legislative districting schemes," ${ }^{231}$ explaining that the federal system was "conceived out of compromise and concession indispensable to the establishment of our federal republic" and arose from "unique historical circumstances.. ${ }^{232}$ It is an open question whether this is sufficient to justify the differential treatment. ${ }^{233}$ In any event, what is relevant for present purposes is not the wisdom of any particular example of Tailoring, but the fact of Tailoring in contemporary constitutional law.

(b) State Analogs to the Electoral College. The electoral college is another system that deviates from population-based voting. ${ }^{234}$ Under the electoral college that selects the

\footnotetext{
${ }^{229}$ See supra at p. 56.

${ }^{230}$ Two patterns of migration could have occurred. First, the fact that so central a political institution as the Senate does not rely on population-based apportionment could have been relied up on for the principle that American democracy, and equal protection by extension, does not require the States to have population-based apportionment. See Baker v. Carr, 369 U.S. 186, 298-300, 308 (1962)(Harlan, J., dissenting) (making this argument). Conversely, the equal protection principle of population-based apportionment could have been applied to the federal government on the theory that Article

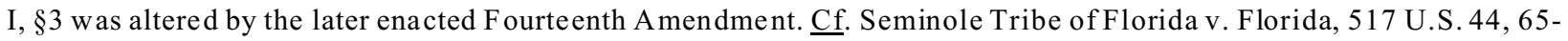
66 (1996)(holding that Congress can subject States to suit in federal courts for violation of federal law enacted pursuant to $\S 5$ of the Fourteenth Amendment, but not Article I, because the $\S 5$ altered the earlier-enacted Eleventh Amendment). The former is the more likely of the two insofar as the latter would constitute an extraordinary alteration of our country's political structure. On the other hand, powerful normative arguments have been formulated in opposition to area-based apportionment. See, e.g., DAhL, How Dem ocratic?, supra note 225, at 46-50; id. at 144-45.

${ }^{231}$ Reynolds, 377 U.S. at 573; see also Gray v. Sanders, 372 U.S. 368,378 (1963).

${ }^{232}$ Reynolds, 377 U.S. at 574.

${ }^{233}$ See Lucas v. Forty-Fourth General Assembly, 377 U.S. 713, $745-46$ (1964) (Stew art, J., dissenting); Baker v. Carr, 369 U.S. 186, 298-300, 308 (1962)(Harlan, J., dissenting).

${ }^{234}$ See Gray v. Sanders, 372 U.S. 368, 376-77 (1963).
} 
President, each State has a number of Electors equal to the whole number of Senators and Representatives to which it is entitled in the Congress. ${ }^{235}$ Because the Senate is not apportioned on a population basis, the ratio of Electors among the States is not equal to the ratio of the populations among the States. ${ }^{236}$ For this reason, among others, ${ }^{237}$ the results of voting in the electoral college can diverge from the popular vote.

The Court has held that States, however, may not use a voting system analogous to the Electoral College for the election of state officials. ${ }^{238}$ Georgia had a "county unit system," under which counties were allotted units on the basis of their population. The majority in each county determined which primary candidate would be allotted the county's unit. ${ }^{239}$ Because the units were not allocated on a linear population basis, the units were not proportional to population. As a result, rural votes were weighted more heavily than urban votes. ${ }^{240}$ A three-judge United States District Court upheld the Georgia system to the extent that "the disparity against any county is not in excess of the disparity that exists against any state in the most recent electoral college allocation." ${ }^{241}$ The Supreme Court found the analogy to the electoral college to be "inapposite" because it was "the result of specific historical concerns." 242 Irrespective of the fact that equal protection principles do not disqualify the Electoral system, the Court held that the Equal Protection Clause rendered

\footnotetext{
${ }^{235}$ See U.S. CONST. ART. II, §1, cl. 2.

${ }^{236}$ The number of Representatives also diverges from a strict population basis due, among other reasons, to the constitutional requirements that all States have at least one Representative and that no congressional district cross state lines. See U.S. Dep't of Commerce v. Montana, 503 U.S. 442, 447-48 (1992).

${ }^{237}$ Another crucial reason is that Electors are awarded on a winner-take-all basis at each State.

${ }^{238}$ See Gray, 372 U.S. at 378-81.

${ }^{239}$ The voting scheme was complex. To be nominated for office, candidates for statewide office were required to receive a majority of both the popular and unit votes. If no candidate received both, a second run-off primary was required between the candidate that received the most popular votes and the one that received the most unit votes. The candidate with the highest number of unit votes would prevail. See $\underline{\mathrm{id}}$. at 372 .

${ }^{240}$ Id. at $372-73$.

${ }^{241}$ Id. at 378 (quoting Gray v. Sanders, 203 F. Supp. 158, 170).

${ }^{242}$ Id. at 378 .
} 
Georgia's analog to the Electoral system unconstitutional. Regardless of whether the Court's proffered distinction is persuasive or not, the electoral college system accordingly stands as yet another example of constitutional principles applying differently to the federal and state governments. $^{243}$

(c) Population-Based Apportionment. Tailoring also is manifested in the differences between States' duties regarding intrastate districting and Congress' duties vis-a-vis interstate districting. State legislatures are responsible for drawing congressional districts for the House of Representatives (intrastate districting). Congress is responsible for determining the number of Representatives that each State has (interstate districting). Intrastate districts drawn by state legislatures are subject to a strict requirement that they be of equal populations. ${ }^{244}$ The relevant constitutional language is Article I, $\S 2$, clause 1, which requires that Representatives be chosen "by the people of the several States." The Court has construed this to "require the States to pursue equality in representation," 245 which in turn has been interpreted as dictating that States make "“a good faith effort to achieve precise mathematical equality’ within each State."246 Population deviations across intrastate districts of as little as one percent have been struck down as violating this constitutional requirement of equality. ${ }^{247}$

\footnotetext{
${ }^{243}$ The Court declared that "all who participate in the election are to have an equal vote ... wherever their home may be in [a] geographical unit. This is required by the Equal Protection Clause of the Fourteenth Amendment. The concept of 'we the people' under the Constitution visualizes no preferred class of voters but equality among those who meet the basic qualifications. The idea that every voter is equal to every other voter in his State, when he casts his ballot in favor of one of several competing candidates, underlies many of our decisions." $\underline{\text { Id. }}$ at 379-80. This logic would suggest that the electoral college violates equal protection, and the Court in Gray offered no explanation as to why the electoral college is exempted.

${ }^{244}$ See U.S. Dep't of Commerce v. Montana, 503 U.S. 442, 460 (1992).

${ }^{245}$ U.S. Dep't of Commerce v. Montana, 503 U.S. 442, 461 (1992); see also $\underline{\text { id. }}$ at 460 (referring to the principle of "equal representation for equal numbers of people").

${ }^{246}$ Id. at 463 (citing Kirkpatrick v. Preisler, 394 U.S. 526, 530-31 (1969)) (emphasis omitted).

${ }^{247}$ See Karcher v. Daggett, 462 U.S. 725 (1983).
} 
The Court in United States Department of Commerce v. Montan $a^{248}$ was confronted with the question whether Congress is held to the same standards in interstate districting to which States are subject in intrastate districting. The precise textual question was whether Article I, §2, clause 3's requirement that Representatives be apportioned among the several States "according to their respective Numbers"'“embodies the same principle of equality" that applies to the States. ${ }^{249}$ A majority of a three-judge District Court had decided that Congress' interstate districting determinations were subject to the same requirements as the States' intradistricting decisions, meaning that "the only population variances that are acceptable are those that are "unavoidable despite a good-faith effort to achieve absolute equality, or for which justification is shown."”250

The United States Supreme Court reversed in a unanimous opinion, concluding that Congress' apportionment method "commands far more deference than a state districting decision ..."251 The doctrinal variation across the federal and state governments accordingly occurs at step 3 , such that $3 . \mathrm{F} \neq 3 . \mathrm{S} .^{252}$ These variations are particularly striking in light of the fact that the Court derived the districting duties incumbent on both the federal and state governments from the same section of the Constitution: Article I, §2.

Once again, the Court pointed to institutional differences between the States and the federal government to explain why doctrinal variations were appropriate. Though intrastate and interstate

\footnotetext{
${ }^{248} 503$ U.S. $442(1992)$.

${ }^{249}$ Id. at 461.

${ }^{250} \underline{I d}$. at 446 (quoting Kirkpatrick, 394 U.S. at 531).

${ }^{251}$ Id. at 464 . While it is difficult to discern the precise standard to which the Court subject Congress' interstate districting decisions, it uncontroversially was far less searching than what the States are subject to. The fact of such Tailoring is all that matters for present purposes.

${ }^{252}$ While it is difficult to discern the precise standard to which the Court subject Congress' interstate districting decisions, see $\underline{\text { id. }}$ at 464-66, it clearly was far less searching than what the States are subject to. See $\underline{\text { id. at }}$ 459-61. The mere fact that the federal and state governments were subject to varying constitutional standards - that is, that the principle of "equal representation" was Tailored as between them - is all that matters for present purposes, that is, for displaying instances of Tailoring in contemporary constitutional law.
} 
districting both are directed at creating equality in representation, the Court ruled that equality means different things across the different institutional contexts of interstate and intrastate districting. At the level of intrastate districting, the requirement of numerical equality is a straightforward concept. Drawing district lines so districts contain equal populations is a task that does not require any tradeoffs because it is driven by a single criterion. The Court concluded that "equality" is a more complex a notion at the interstate level. Because the Constitution itself requires that each State have at least one Representative and forbids the creation of congressional districts that cross state lines, ${ }^{253}$ it almost always is impossible to ensure that congressional districts across all States are of equal size. Because of these limitations, there are multiple, mutually incompatible conceptions of "equality" that an interstate districting scheme could seek to realize. For that reason, concluded the Court, equality in respect of the federal government's interstate districting obligation is an indeterminate concept.

The facts in the Montana case illustrate this. If Montana had prevailed in the litigation and had been awarded an additional congressional district, then the State of Washington would have lost one seat. Bringing Montana closer to the "ideal" district - the nation's population of voters divided by 435 yields the "ideal" district size of equal population districts across the country - would have pushed Washington's eight congressional districts away from the ideal. ${ }^{254}$ Which would have been the preferable outcome from the perspective of equality? The Court concluded that there is no

\footnotetext{
${ }^{253}$ See id. at 447-48.

${ }^{254}$ Under the 1990 census utilized in Montana, the ideal district was 572,466. Under the interstate districting scheme challenged in that case, Montana's population of 803,655 comprised one congressional district and the State of Washington had nine districts that averaged 543,105. If Montana had prevailed, Montana would have had two districts with an average population of 401,838 and Washington would have had eight districts averaging 610,993. In other words, if Montana had prevailed, its districts' deviations from the ideal district would have gone from 231,189 above the ideal to 170,628 below the ideal, whereas Washington's deviation would have gone from 29,361 below the ideal district to 38,527 above the ideal across its eight remaining congressional districts. Bringing Montana closer to the ideal district accordingly would have pushed Washington's congressional districts away from the ideal. $\underline{\text { See }} \underline{\mathrm{id}}$. at 461-62.
} 
uncontroversial conception of equality that can determine which interstate districting plan is more equal, and that great deference accordingly should be given to the federal government's determination. ${ }^{255}$

C. Statutory Examples. This Part of the Article aimed to show that notwithstanding OneSize-Fits-All's predominance, pockets of American constitutional law already reflect sensitivity to the different levels of government. An examination of contemporary law's responsiveness to different levels of government would be remiss if it failed to refer to the many instances where statutory law distinguishes between the different levels of government. For example, although States are exempt from the federal antitrust law, ${ }^{256}$ municipalities are not. ${ }^{257}$ Similarly, states may not be sued under $\S 1983$, but municipalities may be..$^{258}$ Though not direct precedent for constitutional Tailoring, the statutory examples are further evidence that doctrinal sensitivity to the different levels of government is not absent from American jurisprudence.

\section{The Prima Facie Case for Tailoring: That Different Levels of Government May Be RELEVANTLY DifFERENT}

After having argued in Part II that there is no convincing rationale to support a categorical

\footnotetext{
${ }^{255}$ See $\underline{\text { id. }}$ at 464 . What is significant for present purposes is that the Court deemed it necessary to provide an explanation for why the federal and state governments should be treated differently, not whether the explanation ultimately is compelling. I myself am skeptical of the Court's decision in Montana. While notions of equality are more complex in interstate districting than intrastate districting, one candidate stands out from the rest as most consistent across both contexts. The driving principle behind the intrastate district cases is that the weight of each individual's vote should be as equal as possible. See Montana, 503 U.S. at 460 (noting the principle of "equal representation for equal numbers of people"). This is an individual-focused conception of equality that disregards the group to which individuals belong. Applied to the interstate districting context, it would mean that districting should be performed in such a manner that, consistent with the limitations that each State have at least one Representative and that no district cross state lines, the population variances across congressional districts nationwide is minimized. Such an approach reflects an individualfocused conception of equality that disregards the significance of group affiliation (such as what State a person is a citizen of).

${ }^{256}$ See Parker v. Brown, 317 U.S. 341 (1943).

${ }^{257} \underline{\text { See }}$ City of Lafayette v. Louisiana Power \& Light Co., 435 U.S. 389 (1978).

${ }^{258}$ See Monell v. Dep't of Social Services, 436 U.S. 658 (1978).
} 
One-Size-Fits-All (Part II) and having shown in Part III that numerous Justices have embraced Tailoring and that several contemporary doctrines are instances of Tailoring, this Part IV provides a formal analysis of the differences among the different levels of government that may justify Tailoring. It does not delve into the specifics of what constitutional provisions should be Tailored and what the resulting context-sensitive doctrines should look like. Part IV instead makes a generic argument that Tailoring is a sensible option to consider as a prima facie matter. It generates only a prima facie case for Tailoring, not a definitive case, because there are countervailing costs associated with Tailoring, which are identified in Part V.

The basis for the prima facie case, however, is surprisingly robust. It turns out that a broad array of approaches to ordering social life, which typically generate divergent policy prescriptions, concurs that Tailoring may be sound some of the time. Furthermore, though these different methodologies do not generate identical conclusions as to what constitutional guarantees should be Tailored and what the variant doctrines should be, there is considerable overlap in the considerations they deem relevant to determining when Tailoring is appropriate.

Drawing on these competing methodologies, Part IV identifies five broad respects in which different levels of government might be sufficiently different to justify Tailoring: (1) the differing political malfunctions to which each level is susceptible, (2) the distinctive consequences that attend each level's geographical scope, (3) the divergent exit costs across the different levels of government and, correspondingly, the varying extent that efficient and diverse public goods can be generated through a competition among polities, (4) the varying number of people necessary to garner a majority and thereby translate their preferences into law, and (5) each polity's distinctive functions and responsibilities. The analysis suggests that sometimes the central government ought to be 
accorded more leeway to regulate than the lower level governments, and visa-versa.

To be clear, Part IV does not argue that any one of the competing approaches to ordering social life is preferable. The different methodologies rest on different conceptions of personhood and/or conceptions of the appropriate role of government, and choosing among them is an eminently political enterprise. Deciding whether or not to expand Tailoring accordingly would appear to turn on ante-legal commitments that cannot be decided by the Constitution alone.

A. Different Governmental Malfunctions. Several influential schools of constitutional theory conceptualize constitutional law largely as a tool for correcting governmental malfunctions. Many of these analysts have focused on failures in the democratic political process at the legislative level. ${ }^{259}$ Others have noted that many constitutional provisions - primarily those concerning criminal process - aim to keep the executive branch in check by means of prophylactic rules. The discussion below shows that the presence and extent of the political failures to which constitutional doctrine is addressed frequently is a function of the level of government that is acting. From the perspective of malfunction-remedying approaches to constitutionalism, it accordingly would follow that Tailoring is a sensible approach to consider.

1. Malfunctions in the Representative Process. With the exception of the "direct democracy" of initiatives and referendums, polities at all levels of government ${ }^{260}$ in the United States are representative democracies. This system can operate successfully only if elected governmental officials are able to satisfactorily represent the interests of the people. Many theories that understand constitutional law as a remedy for governmental malfunctions have focused on malfunctions relating

\footnotetext{
${ }^{259}$ See, e.g., Ely, supra note 179; Neil K. Komesar, LAw's Limits: The Rule of LAw And The Supply And DEMAND OF Rights (2001).

${ }^{260}$ One further caveat is in order: not all tribal governments function as representative democracies.
} 
to representation. It is useful to break these into three types of representation failures: (1) the absence of representation, (2) under-representation, and (3) over-representation. Careful thought suggests that many of these failures are a function of a polity's size. This provides a prima facie basis under a malfunction-remedying approach to the Constitution for concluding that constitutional doctrines that remedy failures in the representation process may be amenable to Tailoring.

a. Absence of Representation. Consider first the absence of representation. A well-known example is political spillover effects, a type of externality. Such spillover effects are found where a policy pursued by one polity has negative effects on persons in other polities. The democratic malfunction is that parties who are negatively impacted have severely limited opportunities to shape the policies that affect them because they are not members of the political community adopting the policy and accordingly cannot vote. ${ }^{261}$ Constitutional law corrects the problem of negative political externalities by constraining polities from imposing such costs on political outsiders. Many of these constitutional limitations come from the dormant commerce clause and Article IV's privileges and immunities clause. ${ }^{262}$ For example, the dormant commerce clause almost categorically disallows states from discriminating against out-of-staters ${ }^{263}$ and sharply limits states' powers to legislate extraterritorially, ${ }^{264}$ while the privileges and immunities clause allows one state to treat citizens from other states differently from its own citizens only for

\footnotetext{
${ }^{261}$ In Ely's terminology, such political outsiders must rely on insiders to "virtually represent" their interests. ELY, supra note 179, at 82-87. Such virtual representation will not be adequate if the insiders's interests systematically diverge from those of the outsiders. Of course, political outsiders typically can lobby and contribute money to the political campaigns of politicians in whose jurisdictions they do not reside in an effort to have their preferences accounted for.

${ }^{262}$ Another limitation comes from the legislative jurisdiction limitations imposed by the due process clause. See Rosen, Extraterritoriality and Federalism, supra note 216, at 871.

${ }^{263}$ See, e.g., Maine v. Taylor, 477 U.S. 131, 138, 144 (1986) (subjecting such state regulations to strict scrutiny).

${ }^{264}$ See, e.g., Healy v. The Beer Institute, 491 U.S. 324, 346 (1989). For a full discussion of the dormant commerce clause's limitations on extraterritorialism, see Rosen, Extraterritoriality and Federalism, supra note 216, at 919-30.
} 
"substantial reason[s]."

The political malfunction regarding spillover effects disappears, however, when all affected

parties are members of the political community that enacts the law, for there are no unrepresented parties in respect of whom there can be spillovers. The problem of political spillover effects consequently disappears when the Congress acts. ${ }^{266}$ This helps to justify why the constitutional principles of non-discrimination grounded in the dormant commerce clause and the privileges and immunities clause that counteract the political malfunction of spillover effects have not been "reverse incorporated" against the federal government. ${ }^{267}$ Accordingly, although one State cannot discriminate on the basis of citizenship by refusing to allow garbage from another state to be disposed in its landfills, ${ }^{268}$ Congress can authorize the states to discriminate against other states's garbage. ${ }^{269}$ In short, the very existence of this particular political failure is a function of the size of the polity. Consequently, the nature of the Constitution's limitations vary in this context depending upon which level of government is acting. In this Article's parlance, the constitutional principles of anti-discrimination and anti-extraterritoriality are Tailored.

\footnotetext{
${ }^{265}$ See Lunding v. New York Tax Appeals Tribunal, 522 U.S. 287, 298 (1998) (quoting Supreme Court of N.H. v. Piper, 470 U.S. 274, 284 (1985)). For a full discussion of the privileges and immunities clause, see Rosen, Extraterritoriality and Federalism, supra note 216, at 897-909.

${ }^{266}$ This is true at least as far as spillover effects being imposed on U.S. citizens is concerned. There of course may be spillover effects that are felt outside the United States. Various principles of internationallaw, including the principles of legislative jurisdiction, deal with these types of political externalities.

${ }^{267}$ The dormant commerce clause does not apply to Congress. See Maine v. Taylor, 477 U.S. 131, 138 (1986) ("It is well established that Congress may authorize the States to engage in regulation that the Commerce Clause would otherwise forbid."). No case to my knowledge has even contemplated that the privileges and immunities clause's principles apply to the federal government. Furthermore, the Supreme Court long has held that the privileges and immunities clause grants no rights to a citizen as against her own State because state residents "at least have a chance to remedy at the pols any discrimination against them. Out-of-state citizens have no similar opportunity." United Building \& Construction Trades Council v. Mayor of Camden, 465 U.S. 208, 217 (1984); see generally Rosen, Extraterritoriality and Federalism, supra note 216, at 900-903 (discussing cases that establish this principle).

${ }^{268}$ See City of Philadelphia v. New Jersey, 437 U.S. 617 (1978).

${ }^{269}$ See New Y ork v. United States, 505 U.S. 144 (1992) (holding that Congress may grant states the right to refuse to accept another state's radioactive waste, something that states could not have done on their own without congressional authorization).
} 
Similar concerns for spillover effects have led a recent commentator to argue that local regulations should be subject to stricter scrutiny than state or federal regulations across a wide range of constitutional property rights. ${ }^{270}$ Professor William Fischel argues that many constitutional provisions function as intertemporal commitments by governments. Such commitments encourage citizens to engage in activities they otherwise would not due to fear that the government will take the fruits of their labor. Government commitment to keep promises, such as respecting private property, accordingly encourages investment and development today that yields benefits tomorrow. $^{271}$

Fischel argues that smaller governments are more apt to break their promises, and that they accordingly require heightened judicial review:

Left to their own devices, the smaller republics would discount the welfare of underrepresented outsiders. Local insiders can use regulation in a way that subverts the Constitution's clear commands not to take property without compensation. The larger republics are less subject to that temptation because the burden of regulation is more likely to fall on properly represented insiders and their progeny. ${ }^{272}$

The burden of a smaller government's promise-breaking is more likely to fall on unrepresented outsiders because the costs of government promise-breaking today arise only in the future (insofar as current promise-breaking discourages investment today, which will have consequences later), and much of the future population that will suffer is not currently located in smaller jurisdictions on account of the great "mobility of the population." 273 At larger levels of government, by contrast, democratic processes provide a better check on governmental promise-breaking because the costs of promise-breaking are more likely to fall on the people, or the descendants of those, who currently

\footnotetext{
${ }^{270}$ See William A. Fischel, Regulatory Takings: Law, Economics, and Politics (1995).

${ }^{271} \underline{\text { Id. at }}$ 126-31.

${ }^{272}$ Id. at 139.

${ }^{273}$ Id. at 131 .
} 
reside in the polity. In short, Fischel argues that larger governments require less active constitutional oversight by the judiciary because they are less capable of imposing promise-breaking costs on unrepresented outsiders. ${ }^{274}$

Fischel applies his theory to takings doctrine, which currently is One-Size-Fits-All, and concludes that the law should be altered so that smaller polities are subject to greater scrutiny than larger polities. ${ }^{275}$ There is another area of constitutional law Fischel does not mention in this regard that is consistent with his theory. ${ }^{276}$ The Contract Clause, which by its terms applies only to States, is an anti-retroactivity principle that proscribes legislative impairment of contracts. Although there is no analogous constitutional language that addresses the federal government, the Supreme Court long has held that the Fifth Amendment's Due Process Clause imposes anti-retroactivity limitations on the federal government, as well. ${ }^{277}$ It is well established, however, that these anti-retroactivity limitations are not identical. ${ }^{278}$ The Court has offered virtually no justification for the disparate

\footnotetext{
${ }^{274}$ See id. at 131 (providing "an economic-federalism rationale for judicial review" that "[i]n order to run a system in which there are many governments, there must be some external control over opportunistic defaults by one unit whose costs are shifted to others or to the nation as a whole"); $\underline{\text { id. }}$ at 132 (noting a variety of non-judicial constraints on the federal government and states that limit various types of malfeasance but noting that "in the context of local government takings, sometimes courts are the only serious constraint").

${ }^{275}$ See id.

${ }^{276}$ Fischel's analysis focuses only on the contract clause decision of Home Building \& Loan Assn. v. Blaisdsell, 290 U.S. 398 (1934), and mistakenly treats the contract clause as wholly devoid of substantive bite. See FISCHEL, supra note 269, at 130-31. In fact, the Court has relied on the contract clause in striking down two state statutes since Blaisdell was decided. See United Trust Company of New York v. New Jersey, 431 U.S. 1 (1977); Allied Structural Steel Co. v. Spannaus, 438 U.S. 234 (1978).

${ }^{277}$ See, e.g., Pension Benefit Guaranty Corp. v. R.A. Gray \& Company, 467 U.S. 717 (1984).

${ }^{278}$ See Pension Benefit Guaranty, 467 U.S. at 732-33 ("it is suggested that we apply constitutional principles that have been developed under the Contract Clause ... when reviewing this federal legislation. We have never held, however, that the principles embodied in the Fifth Amendment's Due Process Clause are coextensive with prohibitions existing against state impairments of pre-existing contracts. Indeed, to the extent that recent decisions of the Court have addressed the issue, we have contrasted the limitations imposed on States by the Contract Clause with the less searching standards imposed on economic legislation by the Due Process Clauses.") (internal citations omitted); see also Natioal Railroad Passenger Corp. v. Atchison, Topeka and Santa Fe Railway Co., 470 U.S. 451, 472 \& n. 25 (1985) (same).
} 
treatment of the federal and state governments as regards retroactivity. ${ }^{279}$ Fischel's theory provides a plausible answer: the Court appropriately subjects retroactive federal legislation to lower level scrutiny than is given to state legislation ${ }^{280}$ because the federal government is less able to break its promises than are the states. When Congress acts, there are fewer unrepresented outsiders upon whom the externality of promise-breaking could fall by virtue of the fact that Congress represents the interests of a larger bloc of citizens than do either states or municipalities.

b. Under-Representation. Consider next the problem of systematic "under-representation" of discrete and insular minorities that was famously identified by John Hart Ely. Ely argued that the heightened scrutiny that the Court affords to suspect classifications is a proper doctrinal response to political failures where governmental officials systematically disregard the interests of a "discrete and insular" minority for two reasons. First, "widespread hostility" may "distort reality" such that legislators will be unable to see the "overlapping interests that can bind them into a majority on a given issue." 281 As a result, the "wheeling and dealing by which various minorities that make up our society typically interact to protect their interests" may "prove recurrently unavailing." 282 Second, even where there is not such hostility, there might be "subtle[] self-aggrandizing biases of the majority" ${ }^{283}$ that "distort" their perspectives ${ }^{284}$ and result in legislation that is based on problematic stereotypes and generalizations. Ely argued that contemporary constitutional doctrine, which upholds "suspect classifications" only when the state

\footnotetext{
${ }^{279}$ The Court has explained that "[i]t could not justifiably be claimed that the Contract Clause applies, either by its own terms of by convincing historical evidence, to actions of the National Government." Pension Benefit, 467 U.S. at $733 \& \mathrm{n} .9$. The problem with this justification is that the absence of text and history has not kept the Court from incorporating the Bill of Rights's guarantees against the States. See Dorf, supra note 24, at xx, discussed supra at p. x.

${ }^{280}$ See Pension Benefit, 467 U.S. at 732-33.

${ }^{281}$ ELY, supra note 179 , at 153-54.

${ }^{282} \underline{\text { Id. }}$. at 151.

${ }^{283}$ Id. at 161 .

${ }^{284}$ Id. at 160.
} 
can "come up with a goal of substantial weight" and "show that the classification fits that goal with virtual perfection," 285 is a sensible way to identify legislation that is the product of the political malfunctions of hostility or distorted perspectives. ${ }^{286}$

Importantly, the risk of both types of political malfunctions turns on the size and make-up of the polity that is acting. For instance, though there might be "widespread hostility" across the country against a particular group, there might be a majority of that group in a particular sub-federal polity. If so, the very predicate for heightened scrutiny would be absent when such a sub-federal polity acts. Similarly, the self-aggrandizing perceptions that distort the perspective of the majority when the Congress acts, and that appropriately invites the doctrine of suspect classifications and heightened scrutiny under Ely's approach, would not be present if the government that enacted a racial classification (for instance) were a sub-federal polity in which the majority of citizens and representatives belonged to the racial group that constitutes a minority on the national political stage. $^{287}$

Ely's analysis accordingly suggests, at least as a prima facie matter, that whether a given classification constitutes a suspect class that appropriately triggers heightened scrutiny may depend on which level of government has acted. What constitutes a "minority" at the national level, with respect to whom the majority might either be hostile or might systematically misperceive, may not be a minority at the sub-federal level. If the predicate for political malfunction is absent, it would follow that the constitutional doctrine that seeks to remedy the malfunction is inapposite. So, for

\footnotetext{
${ }^{285}$ ELY, supra note 179 , at 146.

${ }^{286}$ Id. at $147-48$.

${ }^{287}$ Under Ely's analysis, there might be relevant differences among different polities for purposes of suspect classifications even if the racial group did not constitute a numerical majority in the sub-federal polity. Ely notes that hostility and stereotyping are likely to be diminished as "social intercourse" among groups increases, $\underline{\text { see }} \underline{\mathrm{id}}$. at 161 , and it is quite possible that the amount of inter-group social interaction might vary across polities.
} 
example, a racial classification might appropriately be subject to heightened scrutiny if enacted by the federal government but only to rational basis scrutiny if enacted by an African-American majority local government. ${ }^{288}$ More generally, Ely's analysis gives rise to the possibility of Tailoring at the levels of 3 and 4 , such that

\section{F $\neq \mathbf{3 . S}$, and/or \\ 4.F $\neq$ 4.S.}

It also suggests that not all sub-federal governments that are situated at the same hierarchical level should be treated the same. A white majority in a municipality, for instance, may be relevantly different for present purposes from an African-American majority in a municipality.

c. Over-Representation. Finally, consider the malfunction I termed "overrepresentation." This refers to a political decision that reflects the desires of the numerical majority that does not take adequate account of the numerical minority's interests. James Madison famously referred to this as the problem of "factions" in the Federalist $10 .{ }^{289}$ Though contemporary readers schooled in public choice may naturally conceptualize "factions" as numerical minorities that can successfully influence governmental action due to their intense desires - that is, as "interest groups" ${ }^{290}$ - this is not what Madison appears to have had in mind. ${ }^{291}$ As Neil Komesar has pointed out, Madison seemed to be of the view in Federalist 42 that numerical minorities are not dangerous: "If a faction consists of less than a majority, relief is supplied by the republican principle, which

\footnotetext{
${ }^{288}$ This would not necessarily be so, however, if the classification burdened the white racial minority in the local

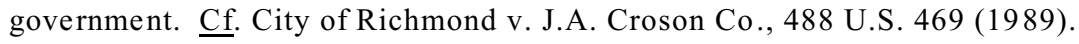

${ }^{289}$ The Federalist Papers 77-78 (Clinton Rossiter, ed. 1961).

${ }^{290}$ See, e.g., Cass Sunstein, Interest Groups in American Public Law, 38 StAN. L. Rev. 29 (1985) (equating Madison's faction with interest groups); Jonathan Macey, Transaction Costs and the Normative Elements of the Public Choice Model: An Application to Constitutional Theory, 74 VA. L. Rev. 471 (1988) (same).

${ }^{291}$ See Neil K. Komesar, Imperfect Alternatives 217-21 (U. Chi. Press. 1994).
} 
enables the majority to defeat its sinister views by regular vote. ${ }^{, 292}$ The problem of factions, instead, arises when the faction is part of the majority: "When a majority is included in a faction, the form of popular Government, on the other hand, enables it to sacrifice to its ruling passion or interest both the public good and the rights of other citizens." Komesar has usefully dubbed this political malfunction the problem of "majoritarian bias."293

Determining what qualifies as majoritarian bias is tricky insofar as it is not simple to explain why a system of rule by numerical majority constitutes a political malfunction. ${ }^{294}$ After all, the right to regulate rule in accordance with the majority's desire is a cornerstone of our democratic government. ${ }^{295}$ Determining if and when majoritarianism is problematic rests on contestable value judgments that are exogenous to democratic theory, and about which people are deeply divided. ${ }^{296}$ In short, identifying why and when laws that reflect the will of the majority constitute a failure of the political process is a deeply political question, and resolving it is beyond the scope of this Article. Regardless of how the political malfunction of over-representation is normatively grounded,

\footnotetext{
${ }^{292}$ FederALIST PAPERS, supra note 288 , at xx.

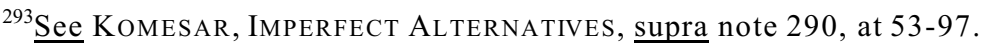

${ }^{294}$ For an illuminating discussion of the normative shortcomings of majority rule, see Christopher J. Peters, Persuasion: A Model of Majoritarianism as Adjudication, 96 Nw. U. L. ReV. 1,2 (2001).

${ }^{295}$ See, e.g., Robert H. Bork, The Tempting of America: The Political Seduction of the Law, 139-41 (1990) (noting the principle of "self-government, which means that in wide areas of life majorities are entitled to rule, if they wish, simply because they are majorities); ELY, supra note 179, at 7 ("whatever the explanation, and granting the qualifications, rule in accord with the consent of a majority of those governed is the core of the American governmental system"). On the other hand, others have argued that many elements of the Constitution reflect a rejection of pure democracy. See, e.g., Robert A. Dahl, How Democratic is the American Constitution? (2001) (noting and bemoaning this); Randy E. Barnett, Constitutional Legitimacy, 103 Colum. L. Rev. 111, 128 (2003). For present purposes I will leave aside the question of supermajority and supramajority rules.

${ }^{296}$ For instance, although it readily can be shown that rule by a pure numerical majority can lead to inefficient outcomes, see KOMESAR, LAW's Limits, supra note 258, at 64-67, it is not axiomatic that obtaining efficient outcomes is the end goal of democratic lawmaking. Similarly, although many might think it unfair for a numerical minority's interests to be systematically disregard in a solely majoritarian-regarding political process, see $\underline{i d}$. at 65 , any such fairness principle also is exogenous to democratic theory. Indeed, Neil Komesar forthrightly acknowledges that determining whether majoritiarian influences constitute a political malfunction in any given instance of governmental action turns on normative considerations. See id. at 64; KOMESAR, IMPERFECT ALTERNATIVES, supra note 290, at 76- 80 (the chosen "social goal" determines whether legislation appropriately reflects the desires of the majority or problematically reflects majoritarian bias).
} 
however, the discussion immediately below shows that the extent of this political failure (for those who identify it as such) will likely be a function of the polity's size. The logic that inclines these people to conceptualize constitutionalism as a remedy for the political malfunction of majoritarianism accordingly should lead them to a prima facie conclusion that Tailoring is a doctrinal option that ought to be considered.

(i) Federalist 10. First consider Madison. He proposed that the problem of factions is tamed, if not solved, to the extent a polity "[e]xtend[s] the sphere."2977 By this, Madison meant extending the borders of the relevant political unit and accordingly enlarging it. "Extend the sphere," wrote Madison, "and you take in a greater variety of parties and interests; you make it less probable that a majority of the whole will have a common motive to invade the rights of other citizens; or if such a common motive exists, it will be more difficult for all who feel it to discover their own strength and to act in unison with each other."298

To be sure, the discussion in Federalist 10 was not intended to give guidance to courts, but instead sought to explain the benefit of a "large over a small republic."299 Supreme Court Justices, however, have understood Madison's insight to have implications in respect of constitutional principles that remedy political malfunctions. Thus it is these very passages from the Federalist 10 that Justice Scalia quoted in his concurring opinion in the Croson decision, and that Justice Stevens cited in his dissent in Adarand, to support the proposition that the dangers of racial discrimination are greater at lower levels of government than at higher levels. ${ }^{300}$ The lower likelihood of factionalism at the higher level of government was the predicate for these Justices's conclusion that

\footnotetext{
${ }^{297}$ FEDERALIST PAPERS, supra note 288 , at 83 .

${ }^{298}$ Id.

${ }^{299} \underline{\mathrm{Id}}$.

${ }^{300} \underline{\text { See }}$ supra at Part II.B.1.
} 
congressional enactments of benign racial classifications should be subject to a lower level of judicial scrutiny than racial classifications created by states or localities. ${ }^{301}$

The Justices's arguments based on the Federalist 10 can be usefully restated as follows: The content of the constitutional principle of equal protection appropriately varies across polities of different size when the political malfunction that equal protection seeks to remedy is a function of the polity's size, and "factionalism" is one such political malfunction. This logic can be generalized: to the extent a constitutional principle remedies the political malfunction of majoritarianism, there is a prima facie basis for concluding that the principle should be Tailored depending upon the level of government whose activity is being reviewed.

(ii) Komesar's "Two-Force” Model of Politics. Professor Neil Komesar has propounded a rich theory of politics that builds on public choice's interest group theory. Komesar identifies political malfunctions and construes various constitutional provisions as remedies for certain types of political malfunctions. His account suggests that the nature and extent of political failure is a function of the level of government that has acted. It follows that constitutional doctrines also may vary in accordance with the level of government that has acted.

Komesar identifies two types of political malfunctions: "majoritarian" and "minoritarian" bias. ${ }^{302}$ Minoritarian bias refers to the legislative distortions recognized by interest group politics: the ability of groups with small numbers but high stakes to organize and successfully lobby for laws that benefit them at the expense of a diffuse majority that fails to press their interests due to the transactions costs of organizing a large group, free rider problems, and relatively low per capita

\footnotetext{
${ }^{301}$ See $\underline{\text { id. }}$. As discussed above, Justice Scalia abandoned this analysis in Adarand when he embraced the principle of congruence. See $\underline{\mathrm{id}}$.

${ }^{302}$ See LAW's Limits, supra note 258, at 60-70.
} 
stakes. ${ }^{303}$ Majoritarian bias, as discussed above, is the converse situation of numerical majorities winning laws that advance their interests at the expense of minorities. Komesar astutely notes that determining whether any given policy is an instance of legitimate governmental response to majority desires ("majoritarian influence," which is not a political malfunction) or illegitimate invasion of minority interests at the behest of the majority (the political malfunction of "majoritarian bias") turns on the normative metric used to evaluate the governmental action. ${ }^{304}$ The same need for a normative baseline besets efforts to distinguish minoritarian influence from minoritarian bias. ${ }^{305}$ Though the line between welcome influence and dysfunctional bias thus is bound to be deeply contested, Komesar is probably right when he states that there is a "pervasive, though amorphous, intuition that both simply counting noses without considering the degree and extent of impacts [majoritarianism] and simply ministering to the desires of the active few [minoritarianism] can sometimes lead to severe injustice." ${ }^{306}$

For present purposes we need not establish what normative baseline is appropriate. What matters instead is that we have an understanding of the dynamics of majoritarian and minoritarian influence on the political process. Under Komear's account, the nature and extent of each type of influence systematically varies on the basis of which level of government is acting. This suggests that there is a prima facie basis for concluding that multi-level constitutional doctrines may vary in their application depending on which level of government is acting.

Under Komesar's analysis, whether majoritarian or minoritarian influence prevails in a given

\footnotetext{
${ }^{303}$ See Komesar, Imperfect Alternatives, supra note 290, at 54-58; Daniel A. Farber \& Philip P. Frickey, Public Choice Revisited, 96 Mich. L. REV. 1715, 1718 (1998).

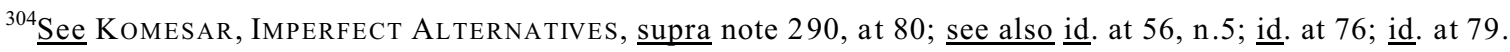

${ }^{305}$ See id. at 80 .

${ }^{306}$ Id. at 81 .
} 
situation is a function of the costs and benefits of participating in the political process that are faced by the majority and minority. ${ }^{307}$ The costs are a function of the size and complexity of the political process (which is a function of the number of legislators, "the frequency of elections, the size and scope of the legislative agenda, and the rules of the legislature" ${ }^{n 308}$ ), the complexity of the substantive issue, and the cost of organizing the group (which is a function of the group size and the information costs of educating the group members). ${ }^{309}$ The relevant benefits of participation are the per capita stakes and the distribution of the potential benefits. ${ }^{310}$ The costs and benefits typically will vary depending upon the size of the group that shares a common interest. All other things being equal, it is easier to organize smaller groups than larger groups because it is cheaper to educate smaller groups of people and less expensive to form and police agreements among smaller groups. ${ }^{311}$ If the benefits exceed costs for the minority but not the majority, then minority influence is likely to prevail over majority influence. If the benefits exceed costs for both the majority and minority, then majority influence is likely to prevail. ${ }^{312}$

Importantly, the costs of political participation systematically vary across different levels of government. ${ }^{313}$ Information and agency costs typically increase at higher levels of government. Compare, for instance, participation costs at local versus the federal government. Effective political participation is far cheaper at the local level because lobbying costs are smaller (there are far fewer

\footnotetext{
${ }^{307} \underline{I d}$. at 30 . For a similar analysis of the political economy of land use laws, see WILLIAM A. FiSCHEL, THE Economics of Zoning Laws: A Property Rights Approach to American Land Use Controls (1985) at 209 (majoritarian bias the more common form of political malfunction at suburban level); $\underline{\text { id. }}$ at 211-21 (minoritarian the more likely problem at higher levels of government).

${ }^{308}$ Komesar, IMPERFECT Alternatives, supra note 290, at 73.

${ }^{309}$ See KomeSAR, LAw's Limits, supra note 258, at 62-63.

${ }^{310}$ Komesar, Imperfect Alternatives, supra note 290, at 60-64.

${ }^{311} \underline{\text { Id. }}$. at 69.

${ }^{312} \underline{\text { Id. }}$. at 226 ("As a general matter, an active majority can overwhelm an active minority.").

${ }^{313}$ See KOMESAR, LAW's Limits, supra note 258, at 63 (noting that the likelihood of majoritarian or minoritarian bias is likely to "vary across political issues and political jurisdictions").
} 
politicians that must be lobbied, and the lobbying costs per politician are likely to be far less expensive insofar as it is cheaper to walk into their offices than to fly to Washington), it is "easier to discipline unwanted action at the ballot box ${ }^{{ }^{314}}$ (because it is easier to hold small numbers of representatives politically accountable), and the costs of politically organizing a group of people who feel similarly about a given political issue is smaller since the size of the group is smaller at the local level. $^{315}$ Moreover, the information costs associated with attaining sufficient mastery of the substantive issue so that one can effectively influence politics typically are smaller at the local level, where the issues are less complex and the more immediate personal stakes tends to mean that citizens already have a stock of "general information" that diminishes the costs of obtaining information about even relatively complex matters. ${ }^{316} \quad$ These factors may help explain the robust cross-country, empirical findings of prominent political theorist Robert Dahl and social scientist Edward Tufte that citizen effectiveness and participation is far greater at local levels than the national level. ${ }^{317}$ In any event, Dahl and Tufte's work provides empirical support for Komesar's predictions as regards varying political participation across different levels of government.

The implication of the preceding analysis is that majoritarian influence is far more likely to prevail over the interests of numerical minorities in smaller governmental units than in larger units; because the costs of political participation are smaller in smaller governmental units, majorities can be expected to participate, and hence exert determinative influence by virtue of their numbers, even

\footnotetext{
${ }^{314} \underline{\text { Id. }}$ Komesar, Imperfect Alternatives, supra note 290, at 63.

${ }^{315}$ This analysis simplifies matters somewhat. There are some mediating institutions (such as public interest groups) that represent "common" interests. Such groups, however, tend to operate mostly at the federal level. Moreover, many "common" interests are not represented by any such mediating institutions.

${ }^{316}$ See KOMESAR, LAW's Limits, supra note 258, at 62-63.

${ }^{317}$ See Robert A. Dahl and Edward R. Tufte, Size And Democracy 55 (Stanford U. Press 1973) (“The effects of unit size on participation and effectiveness are .. important within countries."); $\underline{\mathrm{id}}$. at 65(noting that local governments are seen as "more accessible, more subject to their control, more manageable.").
} 
when per capita stakes are relatively small. Conversely, minoritarian influence is more likely to prevail in larger governmental units, where there are higher costs of political participation, per capita benefits frequently are low, and free rider obstacles may hinder if not wholly bar effective political organization by the majority, leaving only small groups with high per capita interests to politically organize and affect policy. To be sure, what is significant under Komesar's analysis is not the legal status of the polity but its physical size; for instance, majoritarian influence is more likely to prevail in a rural county than a large metropolitan city. Nonetheless, generalizations certainly can be made with respect to federal, state, and local governments. For example, minoritarian influence is more likely to prevail at the federal level than at the sub-federal levels. ${ }^{318}$

Understanding the nature of the political malfunction is important to constitutional analysis under Komesar's approach because he suggests that many constitutional provisions are remedies for particular types of political malfunctions. The Anti-Federalists were concerned with curbing minoritarian bias, ${ }^{319}$ but the Constitution that was adopted ultimately reflected the Federalist's concern with controlling majoritarian bias. ${ }^{320}$ In keeping with the Constitution's general antimajoritarianism tendency, Komesar suggests that the takings clause is best understood as a protection against majoritarian bias. ${ }^{321}$ Indeed, Komesar argues that the Taking Clause's requirement of just compensation is structured in a manner that "corrects majoritarian bias, not minoritarian bias.",322 How so? The requirement of just compensation imposes a cost on all taxpayers - the majority -

\footnotetext{
${ }^{318}$ Komesar notes, of course, that political issues sometimes generate sufficient public interest so that majoritarian interests are reflected in federal legislation. See KOMESAR, ImPerfect Alternatives, supra note 290, at 53-55. Indeed, this observation propels Komesar to augment the interest group model of politics, which focuses solely on minoritarian bias. See $\underline{\text { id. }}$.

${ }^{319}$ See Komesar, Imperfect Alternatives, supra note 290, at 219-20.

${ }^{320}$ See id. at 220.

${ }^{321}$ See id. at $99 \&$ n. 20.

${ }^{322}$ Id. at 95.
} 
hence eliminating the majority's incentive to take from the minority. Compensation would not, however, discourage minoritarian bias because the pro rata tax increase small groups would bear by virtue of the takings clause's compensation requirement is smaller than the benefits they could reap by the taking. ${ }^{323}$ Indeed, a judicially administered compensation requirement itself creates new opportunities for minoritarian bias insofar as the judicial process is very costly. ${ }^{324}$ This suggests that if the takings clause were utilized to correct minoritarian bias, it not only would fail in its mission but perversely would make matters worse. ${ }^{325}$ Komesar accordingly argues that takings doctrine should be understood as a remedy for majoritarian bias, and that takings doctrine should review local regulations more strictly than federal regulations because majoritarian bias is far more likely to occur at lower levels of government. ${ }^{326}$

To quickly conclude, the analyses of Madison, Fischel, and Komesar converge on the following principle: constitutional principles designed to correct political malfunctions might vary in their application if the malfunctions they aim to remedy systematically vary from one level of government to another.

2. Prophylactic Rules. It is widely thought that many constitutional doctrines, particularly those relating to criminal procedure, ${ }^{327}$ are prophylactic rules designed to insure against constitutional violations by governmental actors, particularly members of the executive branch such

\footnotetext{
${ }^{323}$ See $\underline{\text { id. }}$ at $95-97$.

${ }^{324}$ See id. at $97-98$.

${ }^{325}$ See $\underline{\mathrm{id}}$.

${ }^{326}$ See $\underline{\mathrm{id}}$.

${ }^{327}$ Prophylactic rules are not limited, however, to criminal procedure. For a discussion of prophylactic rules in the context of speech and equal protection, see David A. Strauss, The Ubiquity of Prophylactic Rules, 55 U. CHI. L. REV. 190, 195-207 (1988).
} 
as police and prosecutors, when they implement government policy. ${ }^{328}$ Prophylactic rules prohibit behaviors that in themselves are not unconstitutional, or require behaviors that in themselves are not constitutionally mandated, for the sake of ensuring that core constitutional rights are not violated. Prophylactic rules hence "overprotect[] the constitutional clause at issue." 329 The Miranda warnings long were understood as paradigmatic prophylactic requirements. ${ }^{330}$

The Court has not articulated a coherent theory regarding prophylactic rules. ${ }^{331}$ This has led to a sizable amount of scholarly discussion of the subject. ${ }^{332}$ The first generation of scholarship identified the phenomenon of prophylactic rules and debated their legitimacy. ${ }^{333}$ The scholarly consensus today is that the Court has the power to fashion such rules. ${ }^{334}$ The second generation of scholarship has considered the appropriate scope of prophylactic rules. ${ }^{335}$ Although not much has

\footnotetext{
${ }^{328}$ See, e.g., Susan R. Klein, Identifying and (Re)Formulating Prophylactic Rules, Safe Harbors, and Incidental Rights in Constitutional Criminal Procedure, 99 Мich. L. Rev. 1030, 1037-44 (2001); Brian K. Landsberg, Safeguarding Constitutional Rights: The Uses and Limits of Prophylactic Rules, 66 TENN. L. REV. 925 (1999); Strauss, Ubiquity, supra note 326, at 190; Joseph D. Grano, Prophylactic Rules in Criminal Procedure: A Question of Article III Legitimacy, 80 Nw. U. L. REv. 100 (1985); but see Evan H. Caminker, Miranda and Some Puzzles of "Prophylactic" Rules, 70 U. CIN. L. REV. 1, 2 (2001)(arguing that "there is no difference in kind, or meaningful difference in degree, between Miranda's so-called prophylactic rule and the run-of-the-mill judicial doctrines routinely constructed by the Court ..."). Professor Caminker's argument can be viewed as an extension of the point made by Professor Strauss in 1988. Consistent with this Article's methodology of identifying competing approaches to ordering social life without deciding among them, I need not here take sides on the issue of whether or not constitutional doctrine generated by the Supreme Court by its nature is prophylactic in character. Regardless of whether prophylactic rules are occasional, ubiquitous, or omnipresent, the same question arises as to the appropriate scope of a doctrine's ban on activities that in and of themselves are not unconstitutional. As argued below, Tailoring is prima facie sensible to the extent that either the likeliho od of misbehavior, or the costs of over-protecting, vary across the different levels of government.

${ }^{329}$ See Klein, Identifying, supra note 327, at 1033.

${ }^{330}$ The Court's opinion in Dickerson v. United States, 120 S. Ct. 2326 (2000), however, muddied the waters with regard to the status of the Miranda warnings. For a fine discussion, see Klein, Identifying, supra note 327, at 1071-76.

${ }^{331}$ In fact, the Court has not spoken with one voice as to whether, in its view, prophylactic rules are legitimate.

${ }^{332}$ See sources referenced above in footnote 327.

${ }^{333}$ See Grano, Article III Legitimacy, supra note 327 (arguing that prophylactic rules are beyond the appropriate scope of powers of Article III courts); Strauss, Ubiquity, supra note 326 (noting the "ubiquity" of prophylactic rules in an effort to establish their legitimacy).

${ }^{334}$ See Klein, Identifying, supra note 327, at 1035 (showing this). Not all Justices agree; Justices Scalia and Thomas appear to be of the view that prophylactic rules are beyond the Court's proper powers. See Dickerson, $120 \mathrm{~S}$. Ct. at xx (Scalia and Thomas, JJ., dissenting).

${ }^{335}$ See Landsberg, Uses and Limits, supra note 327, at 963-976; Klein, Identifying, supra note 327, at xx.
} 
been written yet on this subject, several commentators' analyses, as well as good sense, suggest that the scope of a given prophylactic rule may appropriately vary depending upon the level of government to which the rule is to be applied.

a. The Need to Over-Protect Constitutional Rights. Professor Klein, for example, has argued that prophylactic rules are appropriate when "the Court finds that it cannot otherwise protect a particular constitutional clause," but notes that "[a]lthough in such situations some prophylactic rule is necessary, no particular rule is required - only one that is 'effective." Klein accordingly concludes that prophylactic rules can be modified "as changed circumstances and new data generated by social scientists mandate." Furthermore, the Court can "change the rules by accepting alternate rules provided by Congress, state legislators, federal and state law enforcement agencies and state judges, who may have better knowledge of the circumstances encountered or facts on the ground ...."337 Indeed, Professor Klein shows several instances where the Court has adopted a prophylactic rule and then "signal[ed]",338 to other federal or state actors that they could adopt alternative strategies for protecting the core constitutional right that the Court's prophylactic rule protected. ${ }^{339}$ In some instances states and the federal executive have responded, "attempt[ing] to institute substitute procedures" for the prophylactic rule laid down by the Court. ${ }^{340}$ Not surprisingly, these responses were neither coordinated nor identical, with the result that the federal executive branch and the different states adopted different procedures. ${ }^{341}$

Professor Klein's reasoning suggests that it might be appropriate to Size prophylactic rules.

\footnotetext{
${ }^{336}$ Klein, Identifying, supra note 327 , at 1060 .

${ }^{337}$ Id.

${ }^{338}$ Id. at 1054 .

${ }^{339}$ See id. at 1054-1059.

${ }^{340}$ Id. at 1055 .

${ }^{341} \underline{\text { Id. }}$. For examples, see Klein, Identifying, supra note 327 , at 1054-59.
} 
On her account, prophylactic rules are pragmatic attempts to guard constitutional rights, and a prophylactic rule's scope is determined by whatever the "circumstances" require so that the rule is "effective" in accomplishing its protective goal. The question becomes whether the circumstances that call for prophylactic rules might systematically vary across the different levels of government. Might there, for example, be consistent differences across workers at the different levels of government with regard to such variables as training, skill, accountability to the public, and so forth? If so, the risks of constitutional violation accordingly may vary across the different levels of government.

The answer ultimately is empirical in nature, and it might well vary across subject matter. There seems to be little reason, however, to conclusively presume identicality as among the different levels of government across all relevant variables, as the contemporary doctrine of One-Size-Fits-All does. In the end, considerations of administrability might lead to the conclusion that the Court should not draft one set of prophylactic rules for federal actors and a different set for state actors. But it should be understood that such an election to adopt a One-Size-Fits-All approach to prophylactic rules is driven by pragmatics rather than conceptual necessity. Legalists accordingly should be open-minded to the possibility that there may be sufficient differences across levels of government in some circumstances to justify Tailoring.

\section{b. The Costs of Over-Protection. Whereas Professor Klein's analysis} focuses primarily on what is necessary to protect the constitutional right, it also might be wise to take account of the potential costs of over-protection. ${ }^{342}$ Professor Landsberg suggestively invokes

\footnotetext{
${ }^{342}$ Consideration of such costs are not wholly absent from Professor Klein's analysis, see, e.g., Klein, Identifying, supra note 327, at 1033 (prophylactic rules must be "more effective" than no rule in guarding against constitutional violations and "involve only acceptable costs"), but they receive little direct attention throughout the article.
} 
the concept of "proportionality," which the Court has utilized to limit Congress's powers to enact prophylactic legislation pursuant to its powers under Section 5 of the Fourteenth Amendment, ${ }^{343}$ as a guide. ${ }^{344}$ Though proportionality is notoriously difficult to specify, the concept that serves as its foundation is instructive in the present context. One factor relevant to a proportionality analysis is, as under Professor Klein's approach, the likelihood of constitutional violation absent some prophylactic rule. Proportionality also bids the analyst to consider the costs of over-protection imposed by the prophylactic rule. ${ }^{345}$ Over-protection costs refer to the liberty sacrifices that attend proscribing (or requiring) behaviors that themselves are not constitutionally proscribed (or required) for the sake of protecting core constitutional rights, as well as the consequences of those proscribed or required behaviors. For instance, the exclusionary remedy is a prophylactic rule whose overprotection costs include withholding relevant evidence during prosecution and possibly keeping dangerous persons on the street instead of in prison.

In assessing whether a given prophylactic rule was appropriate in scope, a proportionality analysis thus would take account of the probability of a constitutional violation, the cost of any such violation, and the over-protection costs. I do not mean to suggest that these various considerations can be reduced to a common metric and readily balanced; surely the "costs" of a constitutional violation and the "costs" of over-protection are incommensurable. ${ }^{346}$ I simply mean that a proportionality analysis would take account of the costs of over-protection in the same way that

\footnotetext{
${ }^{343}$ See, e.g., City of Boerne v. Flores, 521 U.S. 507 (1997).

${ }^{344}$ See Land sberg, supra note 327, at 966-67.

${ }^{345} \mathrm{Cf}$. Strauss, Ubiquity, supra note 326 , at 193 \& n. 12.

${ }^{346}$ SeeJoseph Raz, Incommensurability and Agency, in INCOMMENSURABILITY, INCOMPARABILITY, AND PRACTICAL REASON 110 (Ruth CHANG, ED., 1997) ("Incommensurability is the absence of a common measure").
} 
courts typically take account of incommensurable considerations when they decide cases. ${ }^{347}$

Common sense suggests that some over-protection costs may systematicallyvary depending upon which level of government is acting. Such costs are a function of what the government is attempting to accomplish. A prophylactic rule might hinder the government's ability to accomplish a particular task, and the rule's over-protection cost will be a function of the value of that task. Tailoring is implicated to the extent that different levels of government may be responsible for different tasks that have dissimilar values. As discussed above, Justice Jackson and Justice Harlan made just this point. ${ }^{348}$ To provide another concrete example, compare specialized federal agencies and local governments. Imagine a federal agency that were responsible exclusively for preventing and investigating terrorism. The over-protection costs of a prophylactic rule that interfered with the agency's discharge of its duty would not be identical to the over-protection costs of the same rule in respect of local law enforcement that is directed to solving petty crimes. ${ }^{349}$

The point is that there is no good reason to conclusively assume that over-protection costs are identical across different levels of government. To the extent they are not, a proportionality analysis supports the Tailoring of prophylactic rules. Once again, administrability concerns might suggest that it is not wise to create different prophylactic rules for different levels of government.

\footnotetext{
${ }^{347}$ See Brett G. Scharffs, Adjudications and the Problems of Incommensurability, 42 WM. \& MARY L. REV. 1367,1374 (1991)(noting that "[j] udges routinely seek to accomplish the impossible - to commensurate incommensurable values. That they attempt to do so with regularity says something important about the problems of incommensurability, namely that such problems do not foreclose reasoned deliberation and choice.”). For an enlightening discussion of how decisionmakers can decide among incommensurable options, see Elijah Millgram, Incommensurability and Practical Reasoning, in INCOMMENSURABILITY, $\underline{\text { supra }}$ note 345, at 151-69 (focusing on individual decisionmaking under circumstances of incommensurability).

${ }^{348}$ See supra Part III.A.

${ }^{349}$ Time and circumstances will determine which cost is greater. Cf. William J. Stuntz, O.J. Simpson, Bill Clinton, and the Transsubstantive Fourth Amendment, 114 HARV. L. REV. 842, 847-48 (2001) (criticizing contemporary doctrine on the basis that while "the Fourth Amendment treats one crime just like another . . one crime is not just like another. The Fourth Amendment forbids 'unreasonable searches and seizures.' Reasonableness here, as elsewhere in law, requires a balance of gains and losses, benefits and costs," and noting that the benefits of capturing a murderer are "strikingly different" from those of jailing persons who sell marijuana from their homes).
} 
Such a conclusion should be recognized, however, for what it is: a pragmatic determination, and not a judgment of what the Constitution requires as an a priori matter. Indeed, the insight that there is a basis for concluding that federal authorities can be subjected to different prophylactic rules than state and local authorities might be particularly relevant in our post-9/11 world. There is a principled basis for concluding that a federal anti-terrorism agency populated by highly trained experts could be subject to less stringent prophylactic limitations than local police departments owing to the federal agents's higher training and the greater over-protection costs as a result of the agency's responsibility.

B. Differing Geographical Scope. Another difference between the different levels of government is the different geographical scope to which their regulations and other activities apply. For example, Congress's statutes apply nationwide, whereas Chicago's ordinances for the most part apply only within the territorial borders of Chicago. ${ }^{350}$ It is conceivable that the differing geographical scope of different levels of government could be constitutionally significant such that Tailoring is appropriate.

1. Varying Risks and Benefits. The risks and benefits of a regulation frequently are a function of its geographical scope. With regard to risks, consider a regulation banning a particular book on the ground that it is obscene. One constitutional defect of such a regulation is that it interferes with the marketplace of ideas or art. The quantum of the constitutionally problematic interference is smaller if the regulation is the product of a municipality rather than the federal government because a nation-wide proscription interferes with these interests more than a city-wide

\footnotetext{
${ }^{350}$ A caveat is in order: polities have the power to regulate extraterritorially to a certain de gree. See generally Rosen, Extraterritoriality and Federalism, supra note 216, at 877-91945-55. In general, however, the statement above in text is correct.
} 
prohibition does. This was Justice Harlan's point in his dissent in Roth v. United States. ".351 "it seems to me that no overwhelming danger to our freedom to experiment and to gratify our tastes in literature is likely to result from the suppression of a borderline book in one of the States, so long as there is no uniform nation-wide suppression of the book, and so long as other States are free to experiment with the same or bolder books." 352

Justice Harlan's statement contains both a positive and an evaluative statement. As to the former, it seems undeniable that there is a difference in point of fact between the consequences that attend a local proscription and a nation-wide ban. As to the evaluative question of whether this difference in fact ought to be of legal significance, I do not intend here to argue that Justice Harlan's judgment was correct. A legal doctrine that categorically ignores such differences, however, cannot plausibly be said to be self-evidently correct, for the consequences of these differences may go to the heart of what the constitutional provision aims to guard. When this is the case, logic suggests that there must be an argument proffered as to why regulations emanating from two differently situated polities ought to be treated identically by constitutional doctrine. Justice Harlan's dissent provided a reasoned explanation as to why they should not. The Roth majority, however, did not feel it necessary to explain why it adopted a One-Size-Fits-All approach. ${ }^{353}$ One need not concur with Justice Harlan's ultimate evaluation to agree that a categorical and unexplained One-Size-Fits-All

\footnotetext{
${ }^{351} 354$ U.S. 476 (1957).

${ }^{352}$ Id. at 506 (Harlan, J., dissenting). It is possible, of course, that a patchwork of regulations could lead to nationwide banning in effect if national retailers decided not to stock works that were prohibited in any of the markets in which they did business. On the other hand, there remain independent vendors in most locales, and a decision by Barnes and Noble or Amazon not to stock such controversial works likely would serve only to deepen the independent vendors's market appeal.

${ }^{353} \underline{\mathrm{See}} \underline{\mathrm{id}}$. at 476-494. Much of the analysis in Roth presumes identicality of constitutional standards as they apply to the States and to the Federal government. See, e.g., id. at 482 (looking to the "guaranties of freedom of expression in effect" in the States that ratified the Constitution to shed light on the meaning of the First Amendment); id. at 488 (speaking of the need to bar "federal and state intrusion into" the "fundamental freedom of speech and press").
} 
approach is problematic in view of the undeniable differences that attend the different geographical scopes of federal and state regulation.

Next consider the linkage between benefits and geographical scope. Think about regulations of hate speech. In the view of most, hate speech primarily injures the members of the denigrated group about which the speech concerns. Now compare a federal and municipal prohibition against Nazi marches. In the case of a federal ban on such Nazi activity, the benefits would be diffuse because there would be potential victims in only a fraction of the places to which the proscription would apply. The benefits would be far more concentrated if the regulation were adopted by a municipality populated by a significant percentage of Holocaust survivors. ${ }^{354}$ These differences as regards the distribution of benefits frequently can be relevant under contemporary doctrine. For example, although it would not be relevant under today's hate speech doctrine ${ }^{355}$ the presence of a heavily concentrated population with particular needs might be relevant to establishing a "compelling" governmental interest in other contexts. Conversely, widely dispersed benefits may suggest that a regulation has not been narrowly tailored.

2. Varying Expressive Consequences. The "social meaning" of a constitutional rule frequently turns on the level of government to which it applies. For expressive theorists, who believe that social meaning often is an important determinant of constitutional doctrine, ${ }^{356}$ the level of

\footnotetext{
${ }^{354}$ This hypothetical calls to mind, of course, the Nazi Party's effort to march in Skokie, Illinois, a largely Jewish suburb then populated by large numbers of Holocaust survivors. See Collin v. Smith, 578 F.2d 1197 (7th Cir. 1978).

${ }^{355}$ See R.A.V. v. City of St. Paul, Minnesota, 505 U.S. 377, 391-96 (1992)(applying categorical test that did not rely on heightened scrutiny analysis).

${ }^{356}$ See Restatement, supra note 222, at 1551 (arguing that "constitutional practice is pervasively more oriented toward expressive considerations than is generally recognized."). As is true with all the approaches to social ordering explored in this Article, expressivism is not without its critics. See, e.g., Matthew D. Adler, Expressive Theories of Law: A Skeptical Overview, 148 U. PA. L. REV. 1363 (2000).
} 
government that is acting accordingly may be a constitutionally significant consideration. ${ }^{357}$

Expressivists believe it necessary to identify the“"social meaning” of legal doctrine, ${ }^{358}$ by which they mean the messages that are expressed by law and that are "recognizable" by citizens. ${ }^{359}$ Expressivists are of the view that social meaning is an important determinant of constitutional doctrine as a purely descriptive matter. ${ }^{360}$ Expressivists believe this to be a good thing, though they justify this normative conclusion on different grounds. Professors Elizabeth Anderson and Richard Pildes are of the view that legal doctrine appropriately takes account of social meaning because expressing messages invariably is part of what law does. That is to say, understanding a law's expressive component is necessary to fully understand law. ${ }^{361}$ While Anderson and Pildes deliberately try to disassociate expressivism from efforts to identify laws" "direct cultural effects,"”362 apparently due to a concern that courts are not capable of making such "speculative" judgments, ${ }^{363}$ other noted theorists are interested in the ways that law's social meaning socializes citizens. Robert Cooter, for example, speaks of two expressive uses of law, one of which is "[c]hanging individual values." ${ }^{364}$ Similarly, Cass Sunstein argues that law inevitably and properly is involved in "norm

\footnotetext{
${ }^{357}$ Much of the discussion that follows in this subsection draws on my analysis in Mark D. Rosen, Establishment, Expressivism, and Federalism, 78 CHI.-Kent L. Rev. 669 (2003).

${ }^{358}$ See, e.g., Richard H. Pildes, Why Rights Are Not Trumps: Social Meanings, Expressive Harms, and Constitutionalism, 27 J. Legal STUd. 725, 749 (1998).

${ }^{359}$ Restatement, supra note 222, at 1520-27. Elizabeth Anderson and Richard Pildes, among the most important of the expressivist theorists, argue that the social meaning "do not actually have to be recognized by the community" but only "have to be recognizable by it, if people were to exercise enough interpretive self-scrutiny." Id. at 1525 . For more about their understand ing of expression, see Rosen, Expressivim \& Establishment, supra note 356, at 112-15. For a brief discussion about competing schools of expressivist thought, see $\underline{\text { id. }}$. at 113-15.

${ }^{360}$ See Restatement, supra note 222, at 1551 (arguing that "constitutional practice is pervasively more oriented toward expressive considerations than is generally recognized.").

${ }^{361} \underline{\text { Id. }}$ at $1530-31$.

${ }^{362} \underline{\text { Id}}$. at 1560 .

${ }^{363}$ Id.

${ }^{364}$ Robert Cooter, Expressive Law and Economics, 27 J. LEGAL STUd. 585, 586 (1998). The other expressive function Cooter mentions is "[c]reating focal points" that lead to a new equilibrium for a given system of social norms. $\underline{\text { Id }}$. By this, Cooter means law's ability to switch behavior without altering the individual's tastes. Id. at 595. Examples include prohibiting smoking in airports and requiring dog owners to clean up after their pets. Id. It is likely that altering
} 
management," and in "expressing social values" and the "social norms" that constitute the political community. ${ }^{365}$

To understand the possible link between governmental level and social meaning, consider the Establishment Clause. It is not difficult to show that social meaning varies depending upon what level of government - federal, state, or local - is barred from doing the "establishing." A constitutional rule prohibiting a national church precludes the federal government from proclaiming that this is a Christian country. A rule that also disallows the establishment of state or local churches, as our current doctrine does, ${ }^{366}$ expresses wholesale disapproval of the intermixing of secular and religious authority. By contrast, a rule prohibiting a national church but not limiting sub-federal polities - as was the case from the Founding up to the incorporation of the Establishment Clause against the states ${ }^{367}$ - could be said to express neutrality on the issue of intermixing insofar as such a rule disallows a single, nationwide orthodoxy but permits divergent approaches to flourish at the sub-federal level. Indeed, one could not plausibly have described the American political tradition as expressing categorical opposition to the intermixing of religious and political authority during our country's first century inasmuch as there were established churches in six states, ${ }^{368}$ and state and local governments in many cases paid salaries for clergy. ${ }^{369}$

For an expressivist, the fact that a constitutional limitation's social meaning might vary

behavior in this way ultimately leads to a change in societal values, as well.

${ }^{365}$ Cass R. Sunstein, Social Norms and Social Roles, 96 Colum. L. Rev. 903, 907, 910 (1996); see also Cass R. Sunstein, On the Expressive Function of Law, 144 U.PA. L. REv. 2021 (1996) (examining how law effectuates changes in social norms).

${ }^{366}$ See Lee v. Weisman, 505 U.S. 577, 580 (1992); Epperson v. Arkansas, 393 U.S. 97, 103-04 (1968) (“Government in our democracy, state and national, must be neutral in matters of religious theory, doctrine, and practice.”) (emphasis supplied).

${ }^{367}$ Depending on one's view, this occurred either upon the Fourteenth Amendment's adoption or in Everson v. Bd. of Educ., 330 U.S. 1 (1947).

${ }^{368}$ Daniel O. Conkle, Toward a General Theory of the Establishment Clause, 82 Nw. U. L. REV. 1113, 1132 (1988).

${ }^{369}$ See Philip Hamburger, Separation of Church and State (2002). 
depending on the level of government to which the limitation is applied is a prima facie basis for concluding that the constitutional principle may apply differently to the different levels of government, i.e., that it may be appropriate to Size the constitutional guarantee. Whether or not a provision should be Tailored ultimately turns on normative considerations. What follows below in Sections $\mathrm{C}$ through $\mathrm{E}$ is an examination of how a variety of normative approaches answers this question. Though these varying approaches to ordering social life generate divergent policy prescriptions, they all suggest that Tailoring sometimes might be appropriate.

C. Different Exit Costs. Exit costs are another systemic difference among the different levels of government that may have constitutional relevance for purposes of Tailoring. Common sense suggests that it is easier, both financially and emotionally, to leave smaller polities than larger ones. As will be shown, the empirical data supports this. As exit costs diminish, it is increasingly realistic to make two related assumptions: that (1) citizens make active choices where to live and (2) polities compete among each other for citizens. This is deemed to be beneficial by several approaches to ordering social life. Economists (and their law and economics cousins) argue that such competition among polities leads to greater efficiencies as well as increased diversity than a less competitive system. Easy exit also is a precondition of the "framework for utopias" described by libertarian political theorist Robert Nozick. ${ }^{370}$

What connection do reduced exit costs and the normative commitments that view them favorably have to constitutional interpretation? The answer is this: Once it is realized that Tailoring is a doctrinal option that is not precluded by the Constitution itself - the point made in Parts I and

\footnotetext{
${ }^{370}$ See Robert Nozick, Anarchy, State, And Utopia 312 (1974). As will be shown below in section D, exit also plays a prominent role in John Rawls's political thought, though it does not assume the centrality that it plays in the approaches adopted by economists and Nozick.
} 
II of this Article - whether to Size invariably becomes a question that turns on the constitutional interpreter's pre-legal commitments. Under either a law and econmics or Nozickean approach, the nature and extent of exit costs are relevant to determining the powers and limits of any given level of government. It would follow that a systemic difference in respect of exit costs would be doctrinally relevant to the interpretation of constitutional provisions that concern the powers and limits of the different levels of government. It is in this respect that exit costs are doctrinally relevant to Tailoring constitutional provisions.

1. That Smaller Polities Have Smaller Exit Costs. Exit costs refers to the cost of leaving one polity for another. ${ }^{371}$ In general, it is easier to exit smaller polities than larger polities. Moving from a large polity to a new jurisdiction on average will require a move of a greater distance than will a move from a smaller polity to a new jurisdiction. Moving costs generally increase with the distance of the move. Many of the nonfinancial costs of moving also tend to increase with distance moved. Short moves need not disrupt networks of friends, family and job in the way that long-distant moves typically do. Short moves do not necessitate the relocation of new doctors, dentists, shopping, and other resources in the way that longer-distance moves do.

Data concerning mobility supports the hypothesis that exit costs are smaller for shorter moves. To begin, it is worthwhile to note that the evidence shows that Americans move a great deal. Between March 1999 and March 2000, for instance, 43.4 million Americans moved. ${ }^{372}$ This amounts to $16.1 \%$ of the entire population. ${ }^{373}$ This is not unusual. From 1990 to 2000, the percentage of the population that has moved on a yearly basis has ranged from $15.9 \%$ to $17.3 \%$, and

\footnotetext{
${ }^{371}$ See Albert Hirschman, Exit, Voice and Loyalty (1973).

${ }^{372}$ See Jason Schacter, Current Population Reports: March 1999-March 2000 (U.S. Department of Commerce, May 2001 ) (available at www.census.gov/prod/2001pubs/p20-538.pdf) ["Population Reports"].

${ }^{373}$ Id. at $1-2$.
} 
between the years 1947 to 1969 at least $19 \%$, and as much as $21.2 \%$ of the population, moved in a one-year period. ${ }^{374}$ Interestingly, the likelihood of moving is inversely proportional to income. Between March 1999 and March 2000, “[p]eople living in households in lower-income categories were more likely to move than those in higher-income categories: 21 percent for incomes under $\$ 25,000$, compared with $12 \%$ for incomes over $\$ 100,000$," and "[t]hose with income below the poverty level were more likely to have moved (28\%) than those with income $150 \%$ above the poverty level or higher (14\%)."375

Now consider the distribution with respect to distance moved. Between March 1999 and March 2000, approximately $56 \%$ of the moves were local, meaning within the same county, and an additional 20\% were between counties in the same state. ${ }^{376}$ About $19 \%$ were moves to a different state. Approximately $5 \%$ of all moves were outside the country. ${ }^{377}$ Unfortunately, census figures do not distinguish between those intra-county moves that are intra-municipality and those that are inter-municipality. Working with similar data from a few years before, however, one noted commentator wrote that a "conservative estimate is that approximately $20 \%$ of the population will move to a different political jurisdiction in a five-year period." ${ }^{378}$

In short, Americans are quite mobile. Most moves are short-distance; the mobility rate diminishes with distance moved. This data supports the hypothesis that Americans exercise "exit" from their home jurisdictions with significant regularity. The data also is consistent with the hypothesis that exit from smaller jurisdictions is cheaper than exit from larger jurisdictions, though 
it admittedly does not establish a causal link between exit costs and distance of move.

2. Law and Economics. Economists long have conceptualized the federal political structure as affording the possibility of a competition among sub-federal jurisdictions. In a seminal article, economist Charles Tiebout theorized that local governments compete for citizens by offering different packages of public goods. ${ }^{379}$ Competition generates differences across jurisdictions along two dimensions under this approach. The first is efficiency: jurisdictions will be pressed to deliver their public goods in a cost-efficient way, or people will move away to locate in another jurisdiction that offers the same public goods for less money. Second, jurisdictions will try to differentiate themselves by offering different packages of public goods, which will appeal to different types of citizens. This competition among jurisdictions is normatively desirable in Tiebout's view for two reasons. First, ceteris paribus, the efficient provision of goods is preferable to less efficient provision. Second, greater numbers of options increase consumer welfare; those who value public good "A" can locate themselves in a jurisdiction that provides it, and those that do not can live in a polity that does not so that they'll not have to pay for something they do not value. ${ }^{380}$

Like all economic models, Tiebout's was based on specified ideal conditions that are not fully reflected in the real world. ${ }^{381}$ Tiebout's model has been criticized on the basis that the real

\footnotetext{
${ }^{379}$ See Charles M. Tiebout, A Pure Theory of Local Expenditures, 64 J. Polit. Econ. 416 (1956).

${ }^{380}$ See $\underline{\text { id. }}$.

${ }^{381}$ Tiebout assumed (1) full consumer knowledge about different locations, (2) that people were fully and costlessly mobile, (3) that they lived on dividend income, so employment opportunities were not a factor, (4) that there were a large number of communities, (5) that the different communities did not impose externalities, and that (6) for every package of community services, there's an optimal community size for the provision of those goods. See Tiebout, Pure Theory, supra note 378 . For a slightly modified restatement of Tiebout's conditions and a clear explanation, see Robert P. Inman and Daniel L. Rubinfeld, The Political Economy of Federalism, in Perspectives on Public Choice 73-106(Dennis C. Mueller, ED. 1997).
} 
world's deviations from the model's assumptions fatally undermine the model's utility. ${ }^{382}$ Two points merit mention. First, notwithstanding the fact that the real world is far more complex than the conditions idealized in Tiebout's model, there is a substantial body of empirical data that "provides substantial proof that local jurisdictions do compete for residents" 383 and that "support[s] the core Tiebout proposition that jurisdictions compete for residents by attempting to offer desirable public service / tax packages. ${ }^{9384}$

The second point relates directly to Tailoring. One of the Tiebout model's assumptions is the absence of exit costs. Although there obviously are exit costs in the real world, the quantity of costs is a function of the size of the polity from which a person exits. This is crucial for Tiebout's analysis. Remaining or exiting is the mechanism by which "voter-consumers" choose a bundle of public goods. ${ }^{385}$ Such choice is what induces polities to spend efficiently and carefully tailor the

\footnotetext{
${ }^{382}$ Some have argued that even if the model's assumptions sufficiently represent the real world, modeling public policy in economic terms is normatively problematic. See, e.g., Gerald Frug, City Making: BuILding Comm UnitiES Without Building Walls 171-77 (1999)(criticizing Tiebout's "consumer-oriented vision of city services" and the nature of cities); see also Richard Schragger, Consuming Government, 101 Mich. L. REV. 1824 (2003); Lee Anne Fennell, Homes Rule, 112 YALE L. J. 617 (2002). I'll not explore the second criticism here, insofar as this Article attemp ts to show how competing normative approaches would analyze Tailoring, not to criticize or defend the competing approaches.

${ }^{383}$ Been, "Exit" As Constraint, supra note 377, at 514-15. According to Professor Been, "[e]vidence whether communities compete for residents primarily stems from the efforts of scores of economists and political scientists to test the accuracy of Tiebout's theory that citizens' opportunities to 'vote with their feet' will result in the efficient provision of public goods by local governments. Those studies provide substantial proof that local jurisdictions do compete for residents." $\underline{\text { Id. }}$ (internal citations o mitted).

${ }^{384}$ Been, "Exit" As Constraint, supra note 377, at 527-28. Professor Been surveys multiple empirical studies and concludes that "data about the extent to which differences in public service expenditures and taxes are capitalized into house values, data about the relationship between migration pattern and fiscal characteristics of communities, and data about the increasing homogeneity of communities all support the proposition that consumers consider a community's public service and tax packages when they choose where to live ... "[T]he fact that consumers shop for a public service and tax package is strong evidence supporting the core Tiebout proposition that jurisdictions compete for residents by attempting to offer desirable public service / tax packages." Id.

${ }^{385}$ Professor W illiam A. Fischel's new book builds on Tiebout's model, but offers an important modification of it. Tiebout's assumption of perfect mobility is replaced with the assumption that local governments must be able to restrict new immigrants so as to keep each polity scarce. See William A. Fischel, The Homevoter Hy po thesis: How Home Values Influence Loc al Government Taxation, School Finance, and Land Use Policies 51-57 (Harv. U. Press 2001). This does not undermine the point made above in text, however, concerning exit costs; though the demands of scarcity mean for Fischel that not everyone who wishes to enter a given locale will be able to, local governments will be subjected to market pressures only if exit is possible.
} 
public goods they offer. If exit is not a realistic possibility, these "market" checks on polities are lost. It follows that the potential benefits identified by Tiebout likely are a function of exit costs and, correspondingly, the size of the polity under consideration. For instance, localities will be subject to the market pressure of citizen-consumers more than is the United States since smaller exit costs mean that inter-city moves are more likely than international relocations.

These insights have implications for economic analyses of constitutional law. Under a law and economics methodology, constitutional provisions are construed to generate welfare-enhancing results. ${ }^{386}$ Tieboutian analysis is relevant to the interpretation of constitutional provisions that bear on the powers of the different levels of government. Welfare is enhanced by permitting a competition among jurisdictions in circumstances where voter-consumers realistically can exercise an exit option. There is no a priori reason to exclude policies that implicate constitutional principles from the mix of public goods with respect to which polities can compete. Competition cannot be expected to occur, however, where exit is not a realistic option. Taken together, this analysis suggests that the systemic differences in exit costs across different levels of government are a prima facie basis for Tailoring constitutional principles to different levels of government. Generally speaking, there is less need for judicially enforced constitutional protections at lower levels of government, where exit costs are lower. ${ }^{387}$ As Professor Robert Cooter recently put it,

[i]n general, escaping jurisdiction by a less comprehensive government is easier than escaping jurisdiction by a more comprehensive government. Differences in the cost of exit from different levels of government justify different degrees of vigilance by courts in protecting individual liberties .... The 'exit principle' implies the 'federalism of individual rights,' by which I mean that courts should tolerate more interference with individual liberty

\footnotetext{
${ }^{386} \underline{\text { See generally }}$ Robert D. Cooter, The Strategic Constitution 1-14 (Princeton Univ. Press 2002).

${ }^{387}$ But consider Komesar and Fischel: two economists who, at least in the takings context, advocate more active judicial review of smaller polities.
} 
when the effects are localized. ${ }^{388}$

In short, under a Tieboutian analysis, constitutional principles should be Tailored so that the policies of smaller polities are more deferentially reviewed than regulations from larger polities for two reasons. First, the threat of exit tames polities' policy choices, and the threat of exit is more viable at smaller levels of government, where exit costs are smaller. Second, greater deference to lower levels of government allows for a broader range of regulations at lower levels of government. Citizens accordingly have more options to select among, thereby increasing the welfare of voterconsumers.

To be sure, Cooter's application of Tieboutian principles to constitutional law leaves unanswered many important questions. For example, should every constitutional guarantee be amenable to Tailoring? Are there any firm floors below which a constitutional protection could not be Tailored? If so, what justifies them? The absence of ready replies to these questions means that they require more serious thought, not necessarily that no good answers can be supplied. It is not surprising that such basic question remain open, for there has been virtually no scholarly attention paid to Tailoring up to now. ${ }^{389}$ Consistent with this Article's limited focus, I'll not attempt to answer these particular questions here, particularly since any analysis is likely to be specific to the constitutional protection at issue. ${ }^{390}$ What matters for present purposes is that the economic approach

\footnotetext{
${ }^{388}$ See Strategic Constitution, supra note 385 , at 323 .

${ }^{389}$ Indeed, a lack of satisfactory responses to foundational questions seems to be endemic to the field of constitutional law even with regard to issues that have received vast scholarly attention. For instance, judges and scholars still are deeply divided over what modes of interpretation the Constitution are legitimate. More fundamentally still, scholars to this day discuss the justification for, and implications of, being bound by constitutional text that was drafted and enacted by people of another era, see, e.g., David Strauss, Unwritten Constitution, and debate the justification for the principle of majority rule, see, e.g., Peters, Majoritarianism, supra note 293, at xx.

${ }^{390}$ Consider, for instance, Cooter's analysis of free speech protections. Cooter provides an economic justification for the constitutional protection of speech. Speech is likely to be undersupplied on account of its beneficial externalities, and efficiency demands broad distribution because it is a nonrivalrous good, whose benefits include the transmission of ideas and the stimulation of innovation. $\underline{\mathrm{Id}}$. at 311 . Cooter argues that speech's constitutional protection should increase

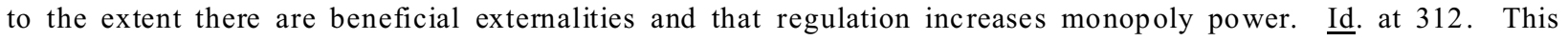


generates a prima facie case for Tailoring constitutional principles. This suggests the wisdom of modifying doctrine so that it can be receptive to such arguments, should they prove to be compelling. This analysis accordingly supports the hypothesis that One-Size-Fits-All should be downgraded from a categorical requirement to a rebuttable presumption.

3. Robert Nozick's “Framework for Utopias". Exit also is a precondition for the libertarian political philosopher Robert Nozick's social vision. Applying Nozickean analysis to our contemporary constitutional order, the systemic differences across different levels of polities with respect to exit suggest that limitations on governmental power ought to vary in accordance with the level of government that is acting.

Nozick famously argued that the ideal state would establish a "framework for utopias"391 within which communities could do almost anything they wanted, subject to only a few caveats. ${ }^{392}$ Nozick's vision takes the form of a federal political structure within which the "central" state apparatus has few regulatory powers but the sub-state regulatory entities ("associations"393 and “communities" 394 in his terminology) may extensively supervise their members' behaviors, if they so choose. ${ }^{395}$ His solution is driven by two assumptions. First, that there are such great differences

justification opens the door to Tailoring because the determination of whether speech imposes any externalities, and if so whether they're beneficial or negative, turns on cultural values that might vary from group to group. If there are different cultural evaluations of this that correspond to different groups that are situated in discrete geographical locations that coincide with political jurisdictions, then an approach designed to maximize preferences would suggest that Tailoring is desirable. Whether or not one agrees with this analysis, the point for present purposes is that the analysis is specific to the particular constitutional guarantee with regard to speech, and does not shed any light on, for instance, the appropriate scope of the contracts clause.

${ }^{391}$ Nozick, supra note 369 , at 312 .

${ }^{392}$ See id. at $320-23$.

${ }^{393}$ See $\underline{\text { id. }}$ at 299 (defining "association" as "a world which all rational inhabitants may leave for any other world they can imagine (in which all the rational inhabitants may leave for any other world they can imagine in which ...").

${ }^{394}$ See, e.g., $\underline{\text { id. }}$ at 307, 309 (using the appellation "community" to describe what Nozick previously defines as "associations").

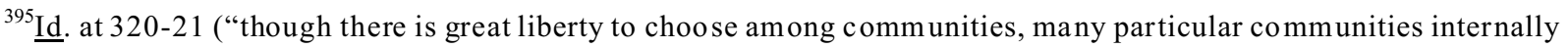
may have many restrictions unjustifiable on libertarian grounds: that is restrictions which libertarians would condemn if they were enforced by a central state apparatus. For example, paternalistic intervention into people's lives, restrictions 
across individuals that it is impossible that any single "utopia" would be best for all of them. ${ }^{396}$ Second, that it is impossible to specify the character of complex social systems in an a priori fashion, but that the development of a society only can occur in an evolutionary process. ${ }^{397}$

Nozick's solution requires a competition among communities to attract adherents. ${ }^{398}$ The competition accomplishes two things. First, it permits experimentation and step-by-step refinement. ${ }^{399}$ Second, it allows there to be different communities that satisfy the needs of different people, thereby increasing overall welfare. ${ }^{400}$ One of the crucial requirements for the framework to succeed is that people can "freely leav[e] their own community to join another." 401 As shown above, ${ }^{402}$ exit is instrumentally necessary for there to be a competition among jurisdictions under a Tieboutian analysis. Even more than this, exit is a foundational precondition under Nozick's libertarian political philosophy. The core of Nozick's approach is that "you choose what you will, with the sole constraint being that others may do the same for themselves and refuse to stay in the

on the range of books which may circulate in the community, limitations on the kinds of sexual behavior, and so on."). Below I discuss the question of whether any polity can function in place of the "communities" (and "associations") that Nozick speaks of, or whether "communities" (and "associations") necessarily must be non-political entities. See infra at p.?.

${ }^{396}$ See id. at 310-11 ("Wittgenstein, Elizabeth Taylor, Bertrand Russell, Thomas Merton, Yogi Berra, Allen Ginsburg, Harry Wolfson, Thoreau, Casey Stengel, The Lubavitcher Rebbe, Picasso, Moses, Einstein, Hugh Heffner, Socrates, Henry Ford, Lenny Bruce, Baba Ram Dass, Gandhi, Sir Edmund Hillary, Raymond Lubitz, Buddha, Frank Sinatra, Columbus, Freud, Norman Mailer, Ayn Rand, Baron Rothschild, Ted Williams, Thomas Edison, H. L. Mencken, Thomas Jefferson, Ralph Ellison, Bobby Fischer, Emma Goldman, Peter Kropotkin, you, and your parents. Is there really one kind of life which is best for each of these people? Imagine all of them living in any utiopia you've ever seen described in detail ... . The idea that there is one best composite answer ... one best society for everyone to live in, seems to me to be an incredible one.").

${ }^{397}$ See id. at 313-15 (arguing that social development must occur by means of "filter devices" rather than "design devices").

${ }^{398}$ See $\underline{\text { id. }}$ at 302 (noting the parallels between his approach and "the economists' model of a competitive market" in which there are "[m]any associations competing for my membership").

${ }^{399}$ See $\underline{i d}$. at 315-19.

${ }^{400}$ See $\underline{\text { id. }}$. at 309 ("if there is a diverse range of communities, then (putting it roughly) more persons will be able to come closer to how they wish to live, than if there is only one kind of community").

${ }^{401}$ Id. at 307 ; see also $\underline{\mathrm{id}}$. at 299.

${ }^{402}$ See supra at p. 94 . 
world you have"created. ${ }^{403}$ "You" can choose the world you want to live in and others can either remain or "refuse to stay," however, only if there is a real option to exit.

To what extent can Nozick's approach inform the interpretation of our Constitution? Determining the practical applications of Nozickean theory to our system of government is tricky. Nozick's analysis does not take as a given our Constitution - or any other governmental institutions, for that matter. ${ }^{404}$ Indeed, his approach, if adopted in its entirety, would require a radical retooling of many aspects of our governmental system. ${ }^{405}$ Nonetheless, Nozick's framework still may have policy implications for an analyst who wished to work from within the United States's existing governmental institutions and structure. ${ }^{406}$

I submit that the following is a faithful application of Nozick's analysis to contemporary American constitutional doctrine. The framework for utopias, under which each association under the minimal central government may extensively regulate its members, requires low exit costs from association to association. Small sub-federal polities, with respect to which exit costs are minimal, may be rough contemporary substitutes for Nozick's "associations." ${ }^{\text {407 }}$ Under this approach, states

\footnotetext{
${ }^{403}$ Id. at 302 .

${ }^{404}$ Instead, his analysis proceeds as a thought-experiment that starts with no assumptions concerning current institutions, the size of government, and so forth. See generally $\underline{\text { id. }}$ at 297-306.

${ }^{405}$ For instance, the central government would have far fewer powers than does today's federal government. See id. at 333 (concluding that only a "minimal state" is "morally legitimate" because "any more extensive state would (will) violate the rights of individuals"). Below I discuss what Nozick's analysis implies about sub-federal polities.

${ }^{406}$ American legal scholars certainly appear to believe this to be true. A recent Westlaw search of references to Nozick's Anarchy, State, and Utopia uncovered more than 1,100 citations. Westlaw search conducted on 2.7.03, (Nozick/3 Anarchy) in Journals and Law Reviews library (1120 citations).

${ }^{407}$ Indeed, there might not be very much difference at all between small polities and Nozickean associations. Associations are permitted to redistribute wealth and exert other coercive powers over its members for so long as a person remains a member. See $\underline{\mathrm{id}}$. at 321. Furthermore, Nozick's logic behind permitting coercive regulation in the "face-to-face community" - in such communities "one cannot avoid being directly confronted with what one finds to be offensive [in another person's actions]. How one lives in once's immediate environment is affected," id. at 322) suggests that face-to-face communities should have a monopoly on coercive powers within their geographical locale. Such a monopoly on coercive power within a fixed territory is one of the core characteristics of a "state" for Nozick.

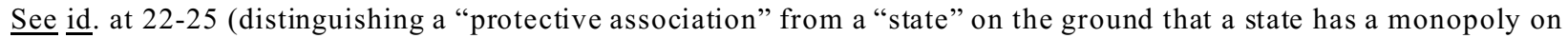
coercive power whereas a protective association has power only in respect of those individuals to decide to pay for its
} 
would be too large to qualify as associations, but many municipalities likely would qualify, as would smaller forms of local government such as villages. Nozick's analysis thus suggests that qualifying small polities should be granted more extensive regulatory powers than large polities. Under our contemporary constitutional order - where the Constitution's constraints have been incorporated against the sub-federal polities - Nozick's analysis accordingly suggests that constitutional principles should be Tailored, such that qualifying small polities be permitted more regulatory powers than are larger polities.

D. Different "We's" and Democratic Theory. Another systemic difference across different levels of government that might justify Tailoring is the number and identity of the polity's citizens. Each polity is constituted by a different "we." The varying number and identity of citizens that are represented in a particular polity can have significant consequences in respect of democratic theory. A limitation on one level of government accordingly might have very different democratic effects when it is applied to another level.

\section{Outsiders' Extraterritorial Interference Versus Insiders' Self-Regulation. A} cornerstone of democratic theory is that, with only limited exceptions, a political community has the right to create laws that bind the entire community if a majority of its members (or its representatives) desire the law. This is paradigmatic democratic self-governance by the political community. Conversely, it is violative of basic democratic principles for outsiders of the political community to dictate laws to the community. Such regulations may be thought of as extraterritorial in nature, and are just a step away from the "taxation without representation" that so vexed our country's forefathers. It follows that a particular regulation could constitute either democratic self-

protection, and thus may be unable to exercise power over all people in a given geographical location). 
governance or its converse depending upon which polity enacted it. Stated differently, the determinant of a regulation's consistency with democracy sometimes may be a function of which polity acted, not the content of the regulation itself. A constitutional principle that aimed at securing democratic principles against interference by outsiders - and there are some, as we shall see below - accordingly would have to be cognizant of which level of government acted. In fact, One-SizeFits-All would be absolutely unsuitable for such a constitutional principle.

The crucial step in determining whether a particular regulation constitutes acceptable democratic self-governance or problematic extraterritorial governance is defining the relevant political community. After all, a regulation that comes from outsiders when the political community is conceptualized as being small can be viewed as an exemplar of self-governance if the relevant political community is more broadly characterized so as to encompass the (former) outsiders. Determining what is the relevant political community is complicated in the United States' federal system because each person simultaneously belongs to multiple political communities - federal and, for most people, ${ }^{408}$ state and local political communities, as well.

In the end, identifying the relevant political community for purposes of determining if a particular regulation instantiates democratic self-governance or its antithesis inevitably is highly context-dependent. Constitutional doctrine that reflects the concern of protecting the integrity of democratic politics, however, must directly confront the question of what constitutes the relevant political community if the doctrine is not to be babble. Sometimes the context is clear enough, such that asking the question leads to a straightforward answer. Even when it does not, the question of

\footnotetext{
${ }^{408}$ Most, but not everybody. For example, citizens of Puerto Rico are citizens of the United States but do not belong to a state. Also, many people live in unincorporated parts of states. Similarly, Native Americans who live on reservations are citizens of the United States and the State in which the reservation is located, but are not citizens of any local governments.
} 
defining the relevant political community is crucial; identifying the relevant political community is the tough question that must be answered, and it is better to confront the real question when tackling difficult constitutional issues.

In this regard, consider the U.S. Term Limits, Inc. v. Thornton ${ }^{409}$ case discussed above. ${ }^{410}$ In striking down an amendment to the Arkansas constitution that was adopted by a ballot initiative, the plurality opinion unthinkingly imported a "fundamental" democratic principle that the Court had developed in the federal context. The plurality's One-Size-Fits-All analysis overlooked the crucial question of what constituted the relevant political community, undermining the cogency of its argument.

The Court had held in the earlier case of Powell v. McCormick ${ }^{411}$ that additional qualifications as to who could be a Congressman that were imposed by Congress when it sought to prevent Adam Clayton Powell, Jr. from taking his seat thwarted the desires of the majority of voters in New York's Eighteenth Congressional District, who had elected him. In so doing, Congress's additional qualifications violated the "fundamental principle of our representative democracy" that "the people should choose whom they please to govern them"412 and accordingly were unconstitutional. The plurality opinion in Thornton concluded that Powell's principle - that additional qualifications undermined fundamental democratic principles - equally applied to conditions (such as term limits) that were imposed by the States, ${ }^{413}$ and struck down Arkansas's

\footnotetext{
${ }^{409} 514$ U.S. 779 (1995).

${ }^{410}$ See supra at $\mathrm{n} .15$ and surrounding text.

${ }^{411} 395$ U.S. 486 (1969). The plurality noted that this was the "most important[]" consideration in its rationale. See 514 U.S. at 806.

${ }^{412} \underline{\text { See }} \mathrm{xx}$.

${ }^{413}$ See $\underline{\text { id. }} 820$ ("the source of the qualification is of little moment in assessing the qualification's restrictive impact.").
} 
amendment on that basis. $^{414}$

The problem with the plurality's reasoning is that it failed to consider who constituted the relevant "people" whose choice had to be respected under fundamental principles of democracy. The democratic principle's application in the Powell case was sensible; the relevant political community whose preferences merited respect clearly was the community defined by the $18^{\text {th }}$ Congressional District, and people outside of that community (members of Congress, who by necessity did not live in Powell's district) were interfering with the District's choice. However, treating Powell's principle in a One-Size-Fits-All manner, as the plurality did in Thornton, actually vitiated the Powell principle. Powell impliedly held that the relevant political community with regard to choosing representatives is the congressional district. A majority of voters in every Arkansas congressional district approved the term limits amendment. Applying the term limit accordingly would have implemented, rather than undermined, the choice of the relevant political community. ${ }^{415}$

In short, the Powell principle relates to a problem of extraterritoriality - outsiders' interference with a political community's choice - not the substance of the regulation. It is not the additional restrictions on who can sit for Congress that were problematic from the perspective of representative democracy, but rather who imposed them. One-Size-Fits-All is flatly illogical in

\footnotetext{
${ }^{414}$ See $\underline{\text { id. }}$.

${ }^{415}$ This does not mean that the ultimate holding in Thornton was wrong, but only that the "most important[]" justification that the plurality provided, $\underline{\mathrm{id}}$. at 806, was ineffectual. There are plausible arguments outside of "fundamental democratic principles" that could have been propounded to strike down Arkansas's amendment. Indeed, understanding the centrality of defining the relevant political community makes clear that an argument based on democratic principles argument was possible. The claim would be that the relevant political community for purposes of laying down the criteria for congresspersons is the national political community. Any such argument, however, would confront several challenges. First, it would have to be explained why qualifications are properly determined by the national political community. In addition to requiring a normative justification, any such claim is in tension with the Powell case's holding that the congressional district is the relevant political community for purposes of selecting congresspersons. Second, this argument is inconsistent with Powell insofar as the argument implies that Congress is the appropriate forum for creating additional qualifications - a principle that Powell squarely rejected.
} 
respect of this type of constitutional principle. Rather, any such constitutional principle that seeks to protect fundamental democratic principles of this sort necessarily must be Tailored.

\section{Limiting the Dilemmas of Majoritarianism. Another systemic difference across}

different levels of government that implicates democratic theory and accordingly might justify Tailoring is the number of voters in the polity. The federal polity encompasses the most voters, whereas states, municipalities, towns, and villages generally have ever-diminishing numbers of voters. To simplify a bit, in a political system characterized by majority rule, the number of voters determines the number of persons that constitutes the majority that can translate its will into law. ${ }^{416}$ Insofar as democracy is "rule by the people," the number of voters in a given polity determines the relevant "we" that can rule itself by choosing policies that more than half its members desire.

The size and make-up of the "we" determines whether idiosyncratic groups can be guaranteed that their political wills can be translated into law in some polity. For example, there were no more than a few thousand members of the Rajneesh religious group in the 1980 s, and it is virtually inconceivable that their idiosyncratic political desires ever would have been shared by a majority of American citizens. By creating the municipality of Rajneeshpuram, ${ }^{417}$ where all citizens were adherents of the Rajneesh creed, the Rajneesh created a "we" that guaranteed that their particular zoning and other needs could become law in some polity.

The realization that there are a multiplicity of possible "we's" complicates democratic theory. Even if one grants the proposition that it is fair that numerical majorities can politically coerce

\footnotetext{
${ }^{416}$ There are two major simplifications in the statement above in text: the text (1) presumes direct rather than representative democracy and (2) ignores coalition-building and log-rolling across issues that can allow numerical minorities to obtain particular laws they might want. The text's simplifying assumptions do not, however, undermine its point concerning the legitimacy of majoritarianism.

${ }^{417}$ See Oregon v. City of Rajneeshpuram, 598 F. Supp. 1208 (D. Ore. 1984). For a discussion of the city of Rajneeshpuram, see Mark D. Rosen, The Outer Limits of Community Self-Governance: A Liberal Theory, 84 VA. L. REV. 1053, 1082-86 (1998).
} 
numerical minorities - a proposition that is not at all self-evident ${ }^{418}$ - how is it to be determined what group constitutes the appropriate "we" from which to search for the "majority's" will? If it is too large, the desires of numerical minorities will be systematically submerged to the wants of majorities. If it is too small, there are risks of balkanization, inefficiencies owing to duplicative governmental institutions, and the coordination problems that attend large numbers of actors (in this case, polities). It seems unlikely that there is a single, a priori solution to this question of how to define the relevant "we." 419

One might think that determining the appropriate "we" is another way of asking the question of how large a democratic political community should be. It might, in which case the query joins a long line of democratic theorists who have asked how small democracies must be to work properly. ${ }^{420}$ On the other hand, there are important differences between the classical theorists and the problem mentioned above. For one, the classic theorists who have been concerned with size did

\footnotetext{
${ }^{418}$ For a good discussion of the problem of majority rule, $\underline{\text { see }}$ Peters, Majoritarianism as Adjudication, supra note 293, at 1-7. Jurgen Habermas, Frank Michelman, and Joshua Cohen try to solve this difficulty by arguing that legitimate democratic institutions permit people to understand themselves as the authors of the laws that bind them, see $\underline{\text { id. }}$. at 3-7, but this approach is unavailing to the extent there exists discrete subgroups in society that have packages of interests that systematically vary from the majority's desires.

${ }^{419}$ See, e.g., Robert Dahl, Dilemm as of Pluralist Democracy 96-100 (1982) (noting the “dilemma" of "a more exclusive versus a more inclusive demos" and concluding that there is no determinate theoretical solution as to how large a democratic polity should be).

${ }^{420}$ Plato calculated the optimal number of citizens at just over five thousand, and Aristotle thought a polity must be large enough so the polity is self-sufficient but small enough so that citizens could "know one another's characters." Dahl \& Tufte, Size And Democracy, supra note 316, at 5-7. Rousseau and Montesquieu also devoted considerable attention to the connection between size and democracy. Id. These theorists' were concerned with size did not grow out of a concern of accommodating a heterogeneous population. Rather, they thought that small size was a precondition for the succ essful op eration of de mocratic polities. Under classical Greek political thought, for example, "[a] democratic polity must have so few citizens that all of them could meet frequently in the popular assembly to listen, to vote, perhaps even to speak. Smallness, it was thought, enhanced the opportunities for participation in and control of the government in many ways. For example, in a small polity every citizen stood a very good chance of being chosen by lot at least once in his lifetime to sit on one of the important administrative bodies. Smallness made it possible for every citizen to know every other, to estimate his qualities, to understand his problems, to develop friendly feelings toward him, to analyze and

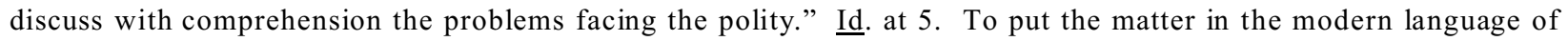
economics, democratic politics was thought to work better in smaller polities because agency and information costs are smaller in such political units. See Inman and Rubinfeld, supra note 380, at 74, 85.
} 
not think about societies that consisted of heterogeneous groups and interests. ${ }^{421}$ Furthermore, the classical democratic theorists assumed that citizens could belong to only a single polity. ${ }^{422}$ This is not the case under the federal political structures of today, where citizens simultaneously belong to multiple political communities.

In fact, the federal political structure holds out the promise of blunting the problem of how to define the relevant "we." The key is that citizens belong to numerous "we's," and they can freely choose what small polity "we" they wish to be part of. The problem is solved, however, only if the smaller-level polities have sufficient political powers to satisfy their citizens' needs. ${ }^{423}$ Tailoring constitutional guarantees, it turns out, is a method for ensuring that such polities enjoy neither too much nor too little political power.

The discussion below draws upon two schools of contemporary political theory to show the connection between defining the relevant "we" and Tailoring. The first subsection discusses the arguments of multiculturalist liberal theorists Will Kymlicka ${ }^{424}$ and Charles Taylor, ${ }^{425}$ who contend that liberal values call for granting to certain groups extensive powers of self-governance that larger polities do not enjoy. Insofar as Tailoring constitutional provisions is a doctrinal mechanism by which such empowerment of select polities can occur, these theorists' arguments are prima facie justifications for Tailoring. The second subsection suggests that foundational liberal commitments captured in John Rawls's account are best realized by taking advantage of the opportunities inherent in the federal political structure's multiple levels of government for permitting citizens flexibility

\footnotetext{
${ }^{421}$ See TAYLOR, supra note 424, at 50-51.

${ }^{422} \mathrm{This}$ is true of all the political theorists referred to above in footnote 419 .

${ }^{423}$ It also turn s on the possibility of exit.

${ }^{424}$ See Will Kymlicka, Multicultur al Citizen ship 94 (1995).

${ }^{425}$ See Charles Taylor, The Politics of Recognition, in Multiculturalism: Examining the Politics of Recognition (Amy Gutmann, ED.) (1994).
} 
in defining the political "we" to which they wish to belong. This provides yet another prima facie basis for Tailoring constitutional provisions.

a. Multicultural Liberal Theorists. In separate works, philosophers Will Kymlicka and Charles Taylor have argued that the foundational liberal principle of equality requires government to take account of the systematic differences among people that account for the discrete "groups" or "cultures" that may be found in a single country. ${ }^{426}$ True equality, they argue, requires that such identifiable groups be treated in ways that are fitted to their idiosyncratic needs. Subjecting groups that systematically differ from the majority to the same laws that apply to the majority does not take account of the groups's differentness and accordingly violates the principle of equal treatment. ${ }^{427}$ In fact, the argument goes, applying one law to all is actually discriminatory; because the majority's approach almost invariably reflects the majority's culture, applying it to nonmajority groups accordingly forces it to adopt the majority's values. ${ }^{428}$

The solutions that Taylor and Kymlicka propose take advantage of federalist systems'

\footnotetext{
${ }^{426} \mathrm{As}$ is true with all the approaches to social ordering canvassed here, Taylor's and Kymlicka's are rejected by many. See, e.g., Brian Barry, Culture and Equality (Harv. Univ. Press. 2001). For a partial response, see Waldron, Logic Of Cultural Accommodation, supra note 426.

${ }^{427}$ See Taylor, supra note 424, at 39 ("we give due acknowledgment only to what is universally present - everyone has an identity - through recognizing what is peculiar to each. The universal demand [of equality] powers an acknowledgment of specificity ... [ [Nondiscrimination requires] that we make ... the ways in which citizens differ . .. the basis of differential treatment."); K YMLICKA, supra note 423, at 108-15. For a concise summary of Kymlicka's argument, see Mark D. Rosen, "Illiberal" Societal Cultures, Liberalism, and American Constitutionalism, 12 J. Contem P. Legal Issues 803, 808-09 (2002). Jeremy Waldron recently has made a similar point. See Jeremy Waldron, One Law for All? The Logic of Cultural Accommodation, 59 WASH. \& LeE L. Rev. 3, 7 (2002) (noting that when "the policy behind [a] statute is in large part itself cultural" that "it surely should be open to the possibility that the same behavior ... might have a quite different cultural meaning to those" from another culture such that "an intelligent application of the rule-of-law ideal seems to militate against the idea of a single rule applying to everyone ...") (emphasis in original).

${ }^{428}$ See Taylor, supra note 424 , at 43 ("the supposedly neutral set of difference-blind principles of the politics of equal dignity is in fact a reflection of one hegemonic culture. As it turns out, then, only the minority or suppressed cultures are being forced to take alien form."); K YMLICKA, supra note 423, at 108 ("Government decisions on languages, internal boundaries, public holidays, and state symbols unavoidably involve recognizing, accommodating, and supporting the needs and identities of particular ethnic and national groups. The state unavoidably promotes certain cultural identities, and thereby disadvantages others.").
} 
capacities to vary the relevant "we." The solutions also support the notion that Tailoring might be desirable. First consider Taylor. His analysis builds on the fact that the minority groups he believes merit differential treatment are situated in geographically discrete territories; the Quebeckers live in Quebec and Canada's aboriginal people primarily live in discrete geographical areas. Taylor explicitly contemplates "[t]he possibility for variation in [the] interpretation" of the Canadian constitution and the Canadian Charter of Rights "in different parts of the country." ${ }^{429}$ He argues that "the standard schedules of rights might apply differently in one cultural context than they do in another, that their application might have to take account of different collective goals. . ."430 Tailoring is a doctrinal mechanism that can accomplishing this insofar as it can accommodate variations of what is constitutionally required across states or municipalities.

Similarly, Kymlicka argues for "self-government rights" that "devolve powers to smaller political units, so that a national minority cannot be outvoted or outbid by the majority on decisions that are of particular importance to their culture . .."431 For Kymlicka, equality requires that "members of the minority have the same opportunity to live and work in their own culture as members of the majority." ${ }^{32}$ Kymlicka argues that the self-governing rights "might well involve

\footnotetext{
${ }^{429}$ Taylor, supra note 424, at 53; see also Taylor, supra note 424, at 61 (supporting the notion that "some variations in the kinds of law we deem [constitutionally] permissible from one cultural context to another . ..").

${ }^{430} \underline{I d}$. at 52 . Elsewhere, however, Taylor argues that "[o]ne has to distinguish the fundamental liberties, those that should never be infringed and therefore ought to be unassailably entrenched, on one hand, from privileges and immunities that are important, but that can ber revoked or restricted for reasons of public policy - although one would need a strong reason to do this - on the other." $\underline{\mathrm{Id}}$. at 59; $\underline{\text { see also }} \underline{\mathrm{id}}$. at 61 (calling for "the invariant defense of certain rights" as "distinguish[ed]" from "the broad range of immunities and presumption of uniform treatment that have sprung up in modern cultures of judicial review."). Taylor is regrettably vague about what falls into the category of categorical "fundamental" rights and what is a rebuttable privilege or immunity. Pildes theory provides a basis for critiquing Taylor's notion of categorical fundamental rights, see supra Part I.C(1).

${ }^{431}$ KYMLICKA, supra note 423 , at 37-38.

${ }^{432}$ Id. at 109 .
} 
exempting the national minority from federal bills of rights and judicial review." ${ }^{433}$ If Kymlicka supports exemption, it stands to reason that he also would endorse the differential application of shared broad principles that Tailoring could provide. After all, Kymlicka is concerned that accommodating minority communities not undermine the mutual solidarity that is necessary to maintain a stable liberal democracy, ${ }^{434}$ and solidarity is more likely under a regime of differential application of shared principles than wholesale exemption from those principles. ${ }^{435}$

Even if one were convinced by Taylor's and Kymlicka's arguments, ${ }^{436}$ it is not clear that there are any groups in the United States today that would qualify as deserving beneficiaries of the special accommodations they advocate. Kymlicka argues that only "national minorities" - those "distinct and potentially self-governing societies incorporated into a larger state" at some point in history are entitled to the rights of self-governance that can secure them the chance to survive, but not groups that have voluntarily immigrated or groups that have been historically marginalized. ${ }^{437}$ Taylor's argument would appear to justify differential treatment for a broader array of groups, but

\footnotetext{
${ }^{433}$ Id. at 168 . To be clear, Kymlicka does not suggest that this outcome is desirable from a liberal perspective. Rather, "[1]iberals in the majority group have to learn to live with this, just as they must live with illiberal laws in other countries." Id. In fact, Kymlicka argues that "any theory which does not accord substantial civil rights to the members of minority cultures is seriously deficient from a liberal point of view." Id. at 164; see also $\underline{i d}$. at 165 . He is particularly critical of any internal limitations imposed by minority groups on their members that "limit the freedom of individual members within the group to revise traditional practices." Id. at 153. Kymlicka also argues that such things as genderbased membership definitions violate liberal principles. See $\underline{\mathrm{id}}$. at 165 . For an argument that liberalism should accommodate some illiberal practices such as these on the part of illiberal minority communities, see Rosen, "Illiberal" Societal Cultures, supra note 426, at 819-31.

${ }^{434}$ See KYMLICKA, supra note 423, at 173-92 (arguing that accommodating minority rights is consistent with maintaining the solidarity necessary to preserve liberal democratic governments).

${ }^{435}$ The only caveat is that the regime of differential application must allow the minority community sufficient room to self-govern that it not "promote alienation and secessionist movements." $\underline{I d}$. at 185 . For a discussion of one such successful regime of differential application of shared principles in the United States, see Rosen, Of Tribal Courts, supra note 29 , at 511-84.

${ }^{436}$ For some who are not, see supra note 425 .

${ }^{437}$ See KYMLICKA, supra note 423, at 19. Native Americans, as well as natives of Puerto Rican and Guam, have been accommodated by creating special polities that do not constitute "states" or "municipalities." See KYMLICKA, supra note 423, at 29. The question of whether these groups have been granted appropriate rights of self-governance lies beyond the scope of this Article.
} 
it too seems to be tied to historical cultures. ${ }^{438}$ One could question whether these Canadian theorists have adopted overly strict criteria for identifying deserving beneficiaries, perhaps owing to the prominence of the Quebec and aboriginal paradigms that figure in their minds. ${ }^{439}$ In any event, their analysis still is relevant even if their criteria are not altered. Even if there currently are not deserving beneficiaries within the United States, Taylor and Kymlicka provide justifications for accommodating future peoples who might become part of the American political community in the future, and Tailoring is a doctrinal mechanism by which these theorists' normative claims can be operationalized in the event there were deserving beneficiaries. These are useful insights. Taylor's and Kymlicka's arguments suggest that Tailoring could be normatively desirable at some point in the future, even if it presently is not. Taylor's and Kymlicka's analyses thus underscore the desirability of not understanding One-Size-Fits-All as a categorical imperative of either liberal commitments or constitutional doctrine.

b. Rawlsian Political Liberalism. The claim that Tailoring is sensible from the perspectives of Kymlicka and Taylor is not difficult to establish because both these multiculturalist theorists explicitly argue that select groups should be given extensive selfgovernance powers. The claim that Rawls also would be open to Tailoring is not as straightforward. Rawls explicitly concludes that government cannot decide "basic questions of justice as [a] person's, or [ ] association's, comprehensive doctrine directs, ${ }^{, 440}$ and this would seem to foreclose the

\footnotetext{
${ }^{438}$ See TAYLOR, supra note 424 , at 66 (justifying the protection of cultures in part on the basis that "all human cultures that have animated whole societies over some considerable stretch of time have something important to say to all human beings").

${ }^{439}$ For such an argument in relation to Kymlicka, see Rosen, "Illiberal" Societal Cultures, supra note 426, at 822-24.

${ }^{440}$ John Ralws, Political Liberalism 62 (1994); see also id. at 196-97 ("Suppose that a particular religion, and the conception of the good belonging to it, can survive only if it controls the machinery of the state ... This religion will cease to exist in the well-ordered society of political liberalism.").
} 
possibility of granting select groups with distinctive cultures extensive powers of self-governance if, as Taylor and Kymlicka suggest, the very point of so doing is to enable the groups to rule themselves in accordance with their distinctive cultural norms and values.

Elsewhere I have critiqued at length this conclusion of Rawls' ${ }^{441}$ I tried to show that foundational Rawlsian premises are more fully achieved by taking account of flexibility inherent in the federal political structure, ${ }^{442}$ which Rawls appears to ignore. ${ }^{443}$ The gist of my argument is that people in an original position, not knowing whether they represented liberals (who do not want the state to take positions on contested visions of the good life) or perfectionists (who think that government must actively promote a vision of the good life if people are to fully self-actualize), would choose to create a federal political structure where liberals could situate themselves in liberal polities and perfectionists could live in perfectionist polities, subject to two caveats: that people in either polity could freely exit and that no polity can undertake activities that threaten the wellorderedness of general society. ${ }^{444}$ People would not select the political structure Rawls suggests where no perfectionist polities can exist - because that would be tantamount to saying that a person in the original position, even though she knew that she might represent a perfectionist, would choose a political structure in which she would be unable to self-actualize in the event she represented a perfectionist, even though she could have chosen a structure in which she would have been able to

\footnotetext{
${ }^{441}$ See Rosen, Outer Limits, supra note 416.

${ }^{442}$ I argue that Rawls' first principle of justice is best achieved by a political structure that permits perfectionists a place where they can self-actualize, see Outer Limits, supra note 416, at 1090-93, and that Rawls' conclusion that perfectionists cannot be accommodated is based on a problematically contested theory of personhood and fails to achieve the strong form of neutrality that accommodation provides, see id. at 1120-25.

${ }^{443}$ See Outer Limits, supra note 416, at 1108-10.

${ }^{444}$ See id. at 1091-1106.
} 
self-actualize regardless of whether she represented a liberal or a perfectionist. ${ }^{445}$ Such an assertion violates the logic of the original position.

In short, my claim is that Rawls problematically overlooks federalism. As a result, he envisions a political framework that is less just than is possible, as measured by his own criteria. ${ }^{446}$ Because my conclusions differ from Rawls' in some very important respects, I refer to my analysis as being "Rawlsian," by which I mean that it is inspired by Rawls's principles. I cannot, and do not, claim that my approach is a straight-forward application of his theory. I do profess, however, that my approach is the best instantiation of his theory. ${ }^{447}$

All this Rawlsian analysis is relevant to constitutional analysis because the Rawlsian method is particularly suited to identifying democratic constitutional institutions. Rawlsian analysis is social contractarian - aimed at identifying the powers that persons willingly would cede to a government of their creation by means of the original position - and democratic authority requires, at least, that the government structure be one to which citizens hypothetically could be said to have consented. ${ }^{448}$ Tailoring constitutional guarantees in sub-federal polities (most likely sub-state polities) where deserving perfectionists live can operationalize the above Rawlsian conclusion.

\footnotetext{
${ }^{445}$ The full argument can be found in Outer Limits, supra note 439, at 1089-1125. Professor Seth Kreimer critiqued this argument of mine in Lines in the Sand: The Importance of Borders in American Federalism, 150 U.PA. L. REV. 973, 1010-1013 (2002), and I responded to his criticisms in Extraterritoriality in American Federalism, supra note 216 , at $967-68 \&$ n. 455.

${ }^{446}$ Stated differently, federalism's capability of allowing multiple "we's" to govern themselves as they largely wish allows for the creation of a political structure that achieves a stronger form of neutrality - that "the state is not to do anything that makes it more likely that individuals accept any particular conception rather than another unless steps are taken to cancel, or to compensate for, the effects of policies that do this," RAW LS, POLITICAL LIBERALISM, supra note 439, at 193 - than Rawls imagines is possible. See Rosen, Outer Limits, supra note 416, at 1124-25.

${ }^{447}$ Id. at 1063 .

${ }^{448}$ For a similar view, see Robert C. Post, Democratic Constitutionalism and Cultural Heterogeneity, 25 AUSTRALIAN J. LEG. PHIL. 185, 185 (2000)(“The enterprise of democratic constitutionalism rests upon the premise of collective agency. If we ask who makes a democratic constitution, the answer must be given in the first person plural . . . The collective agency of the people constitutes a 'demos' capable of 'bestowing . . democratic authority on a polity'") (quoting J.H.H. Weiler, Does Europe Need A Constitution? Demos, Telos and the German Maastricht Decision, 1 Europ. L. J. 219, 238 (1995)).
} 
Constitutional guarantees can be Tailored to afford deserving political perfectionists greater leeway to govern themselves, subject to the above-mentioned constraints of exit and well-orderedness. Tailoring is suited to maintaining the social unity that is required to satisfy well-orderedness; unity is provided by the common constitutional principles that would govern both the perfectionists and others. Varying applications of the principles, which would afford perfectionists greater leeway to run their lives, need not undermine the commonality that joint allegiance to common principles affords, though there surely would be limits on the degree of variation that could be tolerated. ${ }^{449}$ Once again, this Article is not the place to delve into the specifics of what constitutional provisions could be Tailored, and what the doctrines would look like, under a Rawlsian approach. ${ }^{450}$ What matters for present purposes is that a Rawlsian analysis provides prima facie support for Tailoring.

E. Different Functions and Responsibilities. A final respect in which the different levels of government differ is with regard to their functions and responsibilities. As shown above, one of the areas of contemporary doctrine where Tailoring is found -the equal protection jurisprudence that governs "special-purpose units" of government - has been justified by the Supreme Court on this very basis. ${ }^{451}$ Special-purpose units of government may have property-based franchise while "general" governments may not because the former "affect[] definable groups of constituents more than other constituents" by virtue of their unique functions. ${ }^{452}$

More generally, each level of government's distinctive functions would be relevant to

\footnotetext{
${ }^{449}$ See Rosen, Radical Possibility, supra note 25, at 1007 \& n. 317 (considering limits to the degree to which shared principles can be differentially understood without undermining unity).

${ }^{450}$ I provide such an analysis of the Establishment Clause in Rosen, Establishment, Expressivism, and Federalism, supra note 356 , at 669-716.

${ }^{451}$ See supra Part III.B.2.

${ }^{452} 451$ U.S. 355,363 (1981).
} 
constitutional doctrines that either in practice or effect employ a balancing test. ${ }^{453}$ The governmental interest at stake by constitutionally proscribing the regulation of a field would be greater for the level of government primarily or exclusively responsible for that subject matter. This was one of the arguments relied upon by Justices Jackson and Harlan ${ }^{454}$ for giving states greater leeway to regulate speech. Justice Harlan wrote as follows:

The Constitution differentiates between those areas of human conduct subject to the regulation of the States and those subject to the powers of the Federal government. The substantive powers of the two governments, in many instances, are distinct. And in every case where we are called upon to balance the interest in free expression against other interest, it seems important that we should keep in the forefront the question of whether those interests are state or federal. Since under our constitutional scheme the two are not necessarily equivalent, the balancing process must needs often produce different results. Whether a particular limitation on speech or press is to be upheld because it subserves a paramount governmental interest must, to a large extent, I think, depend on whether that government has, under the Constitution, a direct substantive interest, that is, the power to act, in the particular area involved. ${ }^{455}$

In another case, a majority of the Court identified a subject matter that was the federal government's unique responsibility - setting customs policy - and suggested that this might give rise to a unique due process doctrine. Stated the Court,

the two protections [the Fifth and Fourteenth Amendments' due process clauses] are not always coextensive. Not only does the language of the two Amendments differ, but more importantly, there may be overriding national interests which justify selective federal legislation that would be unacceptable for an individual State. ${ }^{456}$

This reason for Tailoring - that the different levels of government have divergent responsibilities - may fall on receptive ears in today's Court. Contemporary commerce clause jurisprudence, for example, turns on distinguishing what is "truly national" from what is "truly

\footnotetext{
${ }^{453}$ This is a more generalized form of the argument with regard to the varying costs of prophylactic measured discussed above. See supra Part IV.A.2. Like all other aspects of this Article's analysis, this argument is premised on a contestable understanding of the role and content of constitutional doctrine.

${ }^{454}$ See discussion supra at p. 43

${ }^{455}$ Roth v. United States, 354 U.S. 476, 504-05 (1968) (Harlan, J., dissenting).

${ }^{456}$ Hampton v. Mow Sun Wong, 426 U.S. 88, 100 (1976) (emphasis supplied).
} 
local. ${ }^{957}$ While many of the subject areas identified by the Court as falling into the latter category might not be so readily characterized as such - for instance, the federal government long has played an important role in family law ${ }^{458}$ - some fields almost certainly fall primarily if not exclusively to federal competence. ${ }^{459}$ Alternatively, even if it is not possible to identify many (or any) subjects that are the exclusive domain of any single level of government, there might be broad agreement that certain subjects are primarily the responsibility of one or the other level of government. This might suffice to have effects on the "balancing" of the government's interest against the countervailing concern protected by a particular constitutional guarantee.

\section{Countervailing Considerations}

This final part analyzes three possible down-sides to Tailoring. It shows that they are considerations that weigh against Tailoring when taking account of Tailoring's benefits and costs, but that they are not reasons for categorically rejecting Tailoring. That Tailoring cannot be categorically rejected is not surprising in light of the twin facts that constitutional law currently contains some examples of Tailoring and many Justices have advocated expanding the instances of Tailoring. ${ }^{460}$

A. Administrability and Judicial Discretion.

Two related disadvantages of Tailoring were discussed earlier in relation to selective

\footnotetext{
${ }^{457}$ United States v. Morrison, 120 S. Ct. 1740 (2000).

${ }^{458} \underline{\text { See }}$ Anne C. Dailey, Federalism and Families, 143 U.PA. L. REV. 1787 (1995); Judith Resnik, 'Naturally' Without Gender: Women, Jurisdiction, and the Federal Courts, 66 N.Y.U. L. REV. 1682 (1991).

${ }^{459}$ Foreign relations comes to mind, though even this is not uncontroversial. See Curtis A. Bradley \& Jack L. Goldsmith, Customary International Law as Federal Common Law: A Critique of the Modern Position, $110 \mathrm{HARV}$. L. REV. 815 (1997) (arguing that customary international law at most rises to the level of state common law, but not federal common law). For contrary views, see Harold Hongju Koh, Is International Law Really State Law?, 111 HARV. L. REV. 1824 (1998); Gerald Neuman, 66 FordHAm L. REV 371 (1997).

${ }^{460}$ See supra Part III.B.
} 
incorporation's eclipse of fundamental fairness: compared to the contemporary One-Size-Fits-All regime, Tailoring would increase the room for judicial discretion and would be more difficult to administer. The concern is that Tailoring would leave the sub-federal polities in the dark as to what are their constitutional obligations. Not only would the doctrines developed in the federal context not necessarily apply to the States, but there might be doctrinal variations as between the States and municipalities, and even across municipalities. The United States Supreme Court hears only about one hundred cases a year, and relieving the sub-federal polities of the obligation to abide by alreadydeveloped constitutional doctrines in effect would leave them to their own devices.

Two factors suggest that although these are very real countervailing considerations against Tailoring, they are not categorical reasons to reject Tailoring. First, as purely descriptive matter, our country's constitutional jurisprudence does not systematically adopt the simplest of all possible legal rules so as to maximize adminstrability and minimize judicial discretion. Many constitutional doctrines are complex. The administrability difficulties they create presumably are justified by the benefits that attend adopting them rather than a simple rule; complexity frequently is needed, and doctrinally adopted, because of the complex mix of considerations that doctrine must mediate. The question accordingly becomes whether Tailoring is a doctrinal complication that is worth its costs. Given the wide array of potential benefits of Tailoring examined in Part IV, it would be surprising to conclude that any and all such benefits would be outweighed by administrative and discretionaugmenting costs. Whether any of the systemic differences between the various levels of government are adequate bases to support Tailoring accordingly can only be answered by considering the costs and benefits that would attend the Tailoring of each particular constitutional guarantee. 
A second reason why these adminstrative and discretion-augmenting concerns are real costs but not categorical reasons to reject Tailoring is that similar costs are borne all the time outside the context of Tailoring. Due to its small size, the Supreme Court is incapable of passing judgment on the vast majority of federal law - constitutional, statutory, and regulatory - that is created. Yet virtually no one takes this as an argument that Congress categorically must legislate less or that administrative agencies must make fewer rules. ${ }^{461}$ Rather, it is understood that large and increasing quantities of law are a concomitant of a large and complex society that must be tolerated, even if such a quantity of regulations invariably makes the legal system more complicated to administer and increases judicial discretion. Consistency accordingly suggests that Tailoring's administrative and discretion-augmenting burdens at most are costs that weigh against Tailoring, but that they are not legitimate bases for rejecting Tailoring as a per se matter.

Another reason to reject the position that administrability and discretion costs render Tailoring categorically undesirable is that the costs themselves are not fixed but are a function of how Tailoring is operationalized. Tailoring could be effectuated in a manner that significantly reduces these costs. One variable is the weight of the presumption that is attached to One-Size-FitsAll. The stronger the presumption, the fewer are the discretion and administrability costs. Second, it could be decided to altogether forgo Tailoring as between certain polities. For example, the costs relating to discretion and administrability would be reduced by not Tailoring as between states and municipalities or across municipalities. The diminished benefits of Tailoring in this limited fashion might be worth it, as a pragmatic matter.

\footnotetext{
${ }^{461}$ This in no small measure is because federal law is reviewed not only by the Supreme Court, but also by lower federal courts, and state courts, as well. Courts aside from the Supreme Court similarly would have reviewing authority under a Tailoring regime.
} 
Regardless of the quantum of the costs, the question arises as to how they are to be balanced against the potential benefits of Tailoring identified in Part IV. The answer is that choosing between them is an eminently "political" process that is not reducible to a purely rational process, but that simultaneously reflects and helps constitute the very character of our national political community. This is so because none of the potential benefits of Tailoring is commensurable with the costs of Tailoring; for example, it is not possible to translate both the benefit of accommodating the needs of certain minority communities (a benefit according to Kymlicka and Taylor) and the costs of increasing discretion and complicating administrability into numbers that can be compared on a common scale. Trading-off among incommensurable goods hence is not a process that can be undertaken by a perfectly rational machine executing an algorithm, but involves subjective value choices that reflect and shape the character of the decisionmaker. ${ }^{462}$ Choosing between One-SizeFits-All and Tailoring thus reflects a doubly subjective, political process: deciding which if any of the potential benefits of Tailoring are to constitute actual benefits for purposes of constitutional doctrine, and then determining how such benefits are to be traded off against the costs relating to judicial discretion and administrability.

B. The Nature of Our Political Union. A profound potential challenge is that Tailoring would risk undermining our Constitution and tearing asunder our national political union. The very point of the Constitution, it might be argued, is to ensure the uniform protection of rights everywhere in the country. Such uniformity is what defines our national character. Moreover, it might be

\footnotetext{
${ }^{462}$ See Mark D. Rosen, Should Un-American Foreign Judgments be Enforced?, 77 MiNN. L. REV. xx (forthcoming Spring 2004); Elijah Millgram, supra note 346, at 151-69; Scharffs, Problematics of Incommensurability, supra note 346.
} 
claimed, uniformity is a prerequisite for citizens' respect for the Constitution. ${ }^{463}$

These may be concerns that weigh against Tailoring, but they are not legitimate grounds for categorically rejecting Tailoring. Let us start the analysis by considering Tailoring across the federal and state governments ("vertical Tailoring"). There are several reasons why it is unlikely that the health of the American Constitution rests on the federal and state governments being subject to identical constitutional constraints. First, it is incontrovertible that prior to the adoption of the Fourteenth Amendment, the Bill of Rights limited only the federal government, not the States. Even after adoption of the Civil Rights Amendments, constitutional limitations continued to vary as between the federal and sub-federal governments under the regime of fundamental fairness. ${ }^{464}$ It was not until the 1960s, when the Court adopted the doctrine of selective incorporation, that constitutional guarantees were systematically applied in identical measure to the federal and subfederal polities. ${ }^{465}$ Even if one prefers selective incorporation to the doctrines that preceded it, it is hard to argue that American constitutionalism is contingent on a type of uniformity that was absent during the majority of this country's existence. ${ }^{466}$ The conclusion that American constitutionalism is not dependent on such uniformity is definitively established by the fact that there are several contemporary examples of vertical Tailoring, such as the equal protection doctrine that permits

\footnotetext{
${ }^{463}$ See Leonard G. Ratner, Majoritarian Constraints on Judicial Review: Congressional Control of Supreme Court Jurisdiction, 27 VILL. L. REV. 929, 941 (1982) (explaining the importance of there being a singular interpretation of constitutional provisions).

${ }^{464}$ See supra at Part I.B.1.

${ }^{465}$ See supra Part I.B.

${ }^{466}$ Given the very different constitutional limitations to which the federal and state governments historically have been subject, it would seem that there is no necessary link between constitutional uniformity across the federal and state governments, on the one hand, and constitutionalism or our nation's political union, on the other. The historical record might be dismissed by the argument that having applied uniform standards is akin to letting the genie out of the bottle, and that reversing the status quo would do damage to constitutionalism at this point in time. But why should this be so? It seems more likely that reversing course would be damaging only if there were not good reasons for doing so and not as a categorical matter.
} 
property-based franchise in certain local governments, ${ }^{467}$ dormant commerce clause doctrine,${ }^{468}$ and area-based and population-based apportionment doctrines. ${ }^{469}$

The harder challenge is Tailoring across states or across municipalities - what might be called "horizontal Tailoring" across polities at the same hierarchical level. A regime under which the U.S. Constitution permitted New York to bar its citizen from doing act " $x$ " in New York but did not permit New Jersey to similarly regulate its citizens undoubtedly would strike many as strange. Nonetheless, is horizontal Tailoring categorically incompatible with American constitutionalism? No. This is proven by the fact that there already is some. Consider the community standards doctrine. Obscene materials receive no First Amendment protection and accordingly can be freely regulated, ${ }^{470}$ but what qualifies as obscene is determined on a place-by-place basis. ${ }^{471}$ The community standards doctrine thus "permit[s] differing levels of obscenity regulation in such diverse communities as Kerrville and Houston, Texas" ${ }^{472}$ with the result that "material may be proscribed in one community but not in another" as a matter of constitutional law. ${ }^{473}$ Less analogous, but still instructive, are the unique constitutional doctrines that apply in military enclaves. For example, although the Bill of Rights applies on military bases, ${ }^{474}$ it is black letter law that "the different character of the military community and of the military mission requires a different application of

\footnotetext{
${ }^{467}$ See supra Part III.B.2.

${ }^{468}$ See supra Part III.B.4.

${ }^{469}$ See supra Part III.B.5.

${ }^{470}$ See Roth v. United States, 354 U.S. 476, 485 (1957).

${ }^{471}$ Hamling v. United States, 418 U.S. 87, 104 (1974). For a more extensive discussion of the community standards doctrine, see Mark D. Rosen, The Radical Possibility of Limited Community-Based Interpretation of the Constitution, 43 WM \& MARY L. REV. 927, 995-97 (2002).

${ }^{472}$ Hoover v. Byrd, 801 F.2d 740, 742 (5th Cir. 1986).

${ }^{473}$ United States v. Peraino, 645 F.2d 548, 551 n.1 (6th Cir. 1981).

${ }^{474}$ See, e.g., Rostker v. Goldberg, 453 U.S. 57, 67 (1981).
} 
[constitutional] protections. ${ }^{\$ 45}$ Thus, there can be prior restraints ${ }^{476}$ and bans on private citizens' political speech ${ }^{477}$ in military enclaves that would not be permitted in states or municipalities. The community standards doctrine and military law strongly suggest that horizontal Tailoring is not categorically incompatible with our constitutional order, for they are contemporary doctrines under which the identical activity may be constitutionally protected in one place (for instance, certain adult magazines in San Francisco) but not in others (the same adult magazines in a more conservative community such as Salt Lake City).

These doctrines, however, are exceptional. What would happen to our constitutional order if what was constitutionally permissible more commonly varied from location to location, as might happen under Tailoring? There would not seem to be anything inherent in constitutionalism that requires, as an a priori matter, that such geography-sensitive constitutional doctrines be exceptional rather than mainstream. Constitutional rights that are "rights, simpliciter" by their nature are not geography-sensitive whereas "rights against rules" may generate doctrines that are geographysensitive to the extent that conditions that are doctrinally relevant vary from place to place, ${ }^{478}$ and I know of no basis for concluding that constitutionalism by its nature requires that "rights, simpliciter" outnumber the "rights-against-rules." Indeed, as a descriptive matter, it seems to be the case that most constitutional rights are of the "right-against-rules" variety.

That jurisprudence does not preclude the mainstreaming of geography-sensitive constitutional

\footnotetext{
${ }^{475}$ Parker v. Levy, 417 U.S. 733, 758 (1974); see also Goldman v. Weinberger, 475 U.S. 503 , 507 (1986) (“Our review of military regulations challenged on First Amendment grounds is far more deferential than constitutional review of similar laws or regulations designed for civilian society.").

${ }^{476}$ Brown v. Glines, 444 U.S. 348 (1980) (upholding Air Force regulation requiring members of the service to obtain approval from commanders before circulating petitions on Air Force bases).

${ }^{477}$ Greer v. Spock, 424 U.S. 828, 837-38 (1976).

${ }^{478}$ See supra Part II.B.
} 
doctrines does not mean that such a modification would be without effects on our constitutional order. Most importantly, it likely would change citizens' views of constitutional law. Change in and of itself is not a bad thing, however, so it must be asked: how would citizens' views change, and would such a change be beneficial or harmful?

Answering these questions first requires an understanding of what attitudes likely inform citizens' current expectation that constitutional doctrines are uniform nationwide. A crucial component, I imagine, is a widespread belief that constitutional rights by necessity are "rights, simpliciter." Once it is understood that many are not - and Tailoring, it should be recalled, is an option only vis-a-vis those constitutional rights that are "rights-against-rules" rather than "rights, simpliciter" ${ }^{\prime 49}$ - citizens' receptivity to horizontal Tailoring is far more likely. Why? Since a constitutional right of the "right-against-rule" variety means that what the Constitution permits to be regulated is highly context-sensitive, the expectation of nationwide uniformity across all polities of a similar type with regard to constitutional protections that are "rights-against-rules" reflects an unrebuttable presumption that all such polities are identical for constitutional purposes. This unrebuttable presumption of identicality, which horizontal Tailoring rejects, ${ }^{480}$ is a less firm foundation for uniform rights than is the "rights, simpliciter" conception of constitutional rights, under which nonuniform constitutional rights are conceptually incoherent.

What underlies the unrebuttable presumption of identicality that grounds the expectation of nationwide uniformity of "rights-against-rules"? The most plausible candidate is the belief that it

\footnotetext{
${ }^{479}$ See supra at p. 37.

${ }^{480}$ For instance, if heightened scrutiny for racial classifications reflects a concern that minorities' interests are not adequately represented in the legislative process due to widespread hostility, then racial classifications created in blackmajority municipalities ought to be subject to different scrutiny than classifications enacted in white-majority municipalities. See supra at p. 285. Under this Ely approach to constitutional rights, different municipalities might sufficiently different from one another to merit differential constitutional treatment.
} 
is the very nationwide uniform application of constitutional rules that helps to constitute our country as a unified polity. While this is a plausible conception of national identity, it by no means is the only possibility. Our country is extraordinarily heterogeneous, and several of the approaches explored in Part IV in essence reflect the view that our country's very real diversity is better managed by offering a menu of options, including possible variations in what regulations are constitutionally permitted across polities of the same level. ${ }^{411}$ In short, the unrebuttable presumption of identicality reflects not some deep and intrinsic need of constitutionalism, but instead mirrors only one of several competing conceptions of our country's national identity and the Constitution's relationship to that identity. Whether horizontal Tailoring is desirable or not thus turns on normative commitments, not the nature of constitutionalism.

It follows that whether the change in citizens' views of constitutional law that would accompany the mainstreaming of geography-sensitive constitutional doctrine turns on contestable normative commitments. This is an issue that I cannot hope to resolve here in this Article. It is enough for present purposes to identify the contestable foundations on which One-Size-Fits-All rests. Finally, it is important to recognize that even if the unrebuttable presumption of identicality were forthrightly adopted as reflecting the preferable conception of our national identity, this would not lead to the rejection of Tailoring generally, but only of horizontal Tailoring.

\section{CONCLUSION}

Although Supreme Court cases typically read as if constitutional principles self-evidently are One-Size-Fits-All, this is not so. Several contemporary constitutional doctrines fit the paradigm of Tailoring, and many Justices have advocated that other constitutional principles be Tailored.

\footnotetext{
${ }^{481}$ This is true, for example, of the multicultural theorists, Nozick, my reading of Rawls, and the law and economics theorist Robert Cooter.
} 
Jurisprudentially, One-Size-Fits-All is not an intrinsic part of American constitutionalism. Though there are real costs that would attend the Tailoring of constitutional principles, they constitute pragmatic concerns, not bases for categorically rejecting Tailoring. The pragmatic analysis that appropriately informs the choice between One-Size-Fits-All and Tailoring necessarily must take account of Tailoring's many potential benefits. The potential benefits result from the fact that the different levels of government systematically vary in important ways. Consequently, a constitutional limitation as applied to one level of government may have very different repercussions when applied to another. Whether any of Tailoring's potential benefits is to count as an actual benefit, however, is a function of the decisionmaker's political preferences. Determining how any such benefits are to be traded-off against Tailoring's costs requires yet another subjective, political choice since Tailoring's costs and benefits are technically incommensurable.

In the end, then, a choice must be made between One-Size-Fits-All and Tailoring, and the decision invariably will be guided by contestable normative commitments. This Article has not sought to engage in the debate as to which normative commitment is superior, but has aimed to highlight the nonaxiomatic and contestable assumptions that lie behind the One-Size-Fits-All approach that typically is viewed as the doctrinal status quo. The choice between One-Size-Fits-All and Tailoring should not be made on the basis of a misperception of constitutional necessity. Given Tailoring's many potential benefits, however, it seems wise to soften the categorical presumption of One-Size-Fits-All to a rebuttable presumption so that the merits of One-Size-Fits-All versus Tailoring can be examined in the incremental manner that is the common law's wisdom. 